\title{
Terrestrial plant microfossils in palaeoenvironmental studies, pollen, microcharcoal and phytolith. Towards a comprehensive understanding of vegetation, fire and climate changes over the past one million years
}

\author{
Daniau Anne-Laure 1, ${ }^{*}$, Desprat Stéphanie 1,2, Aleman Julie C. ${ }^{3,5}$, Bremond Laurent ${ }^{2,5}$, Davis Basil ${ }^{6}$, \\ Fletcher William ${ }^{7}$, Marlon Jennifer R. ${ }^{8}$, Marquer Laurent ${ }^{9}$, Montade Vincent ${ }^{10}$, \\ Morales-Molino César ${ }^{11}$, Naughton Filipa ${ }^{12,13}$, Rius Damien ${ }^{14}$, Urrego Dunia H. ${ }^{15}$
}

\footnotetext{
${ }^{1}$ Environnements et Paléoenvironnements Océaniques et Continentaux (EPOC), Unité Mixte de Recherche (UMR) 5805, Centre National de la Recherche Scientifique (CNRS), Université de Bordeaux, 33615 Pessac, France

2 École Pratique des Hautes Études (EPHE), PSL Research University, 75014 Paris, France

${ }^{3}$ Département de Géographie, Université de Montréal, C.P. 6128, Succ. Centre-Ville, Montréal, Quebec H3C 3J7, Canada

${ }^{4}$ Laboratoire de Foresterie des Régions tropicales et subtropicales, Gembloux Agro-Bio Tech, Université de Liège, Passage des Déportés 2, 5030 Gembloux, Belgium

5 Institut des Sciences de l'Évolution - Montpellier, UMR 5554 CNRS, IRD, Université Montpellier, EPHE, 34000 Montpellier, France

${ }^{6}$ Institute of Earth Surface Dynamics IDYST, Faculté des Géosciences et l'Environnement, University of Lausanne, Batiment Géopolis, CH-1015 Lausanne, Switzerland

7 Department of Geography, School of Environment, Education and Development, University of Manchester, Oxford Road, Manchester M13 9PL, United Kingdom

8 School of Forestry \& Environmental Studies, Yale University, New Haven, CT 06511, USA

${ }^{9}$ Research Group for Terrestrial Palaeoclimates, Max Planck Institute for Chemistry, Hahn-Meitner-Weg 1, 55128 Mainz, Germany

10 University of Goettingen, Department of Palynology and Climate Dynamics, Albrecht-von-Haller Institute for Plant Sciences, Wilhelm-Weber-Str. 2a, 37073 Goettingen, Germany

${ }^{11}$ Institute of Plant Sciences and Oeschger Centre for Climate Change Research, University of Bern, Altenbergrain 21, 3013 Bern, Switzerland

12 Portuguese Sea and Atmosphere Institute (IPMA), Rua Alfredo Magalhães Ramalho 6, 1495-006

Lisboa, Portugal

${ }^{13}$ Center of Marine Sciences (CCMAR), Algarve University, Campus de Gambelas, 8005-139 Faro, Portugal

14 Université de Franche-Comté, Centre National de la Recherche Scientifique (CNRS), Laboratoire Chrono-Environnement, Unité Mixte de Recherche (UMR) 6249, 16, route de Gray, 25030 Besançon cedex, France

15 Geography, College of Life and Environmental Sciences, University of Exeter, Amory Building B302, Rennes Drive, Exeter EX4 4RJ, United Kingdom
}

* Corresponding author : Anne-Laure Daniau, email address : anne-laure.daniau@u-bordeaux.fr 


\begin{abstract}
The Earth has experienced large changes in global and regional climates over the past one million years. Understanding processes and feedbacks that control those past environmental changes is of great interest for better understanding the nature, direction and magnitude of current climate change, its effect on life, and on the physical, biological and chemical processes and ecosystem services important for human well-being. Microfossils from terrestrial plants - pollen, microcharcoal and phytoliths - preserved in terrestrial and marine sedimentary archives are particularly useful tools to document changes in vegetation, fire and land climate. They are well-preserved in a variety of depositional environments and provide quantitative reconstructions of past land cover and climate. Those microfossil data are widely available from public archives, and their spatial coverage includes almost all regions on Earth, including both high and low latitudes and altitudes. Here, we (i) review the laboratory procedures used to extract those microfossils from sediment for microscopic observations and the qualitative and quantitative information they provide, (ii) highlight the importance of regional and global databases for large-scale syntheses of environmental changes, and (iii) review the application of terrestrial plant microfossil records in palaeoclimatology and palaeoecology using key examples from specific regions and past periods.
\end{abstract}

Keywords : Pollen, Microcharcoal, Phytolith, Terrestrial and marine sedimentary archives, Vegetation, Fire, Middle Pleistocene, Last glacial period, Holocene 


\section{Introduction}

The Intergovernmental Panel on Climate Change (IPCC) was established in 1988 by the World Meteorological Organisation (WMO) and the United Nations Environment Programme (UNEP) to provide an assessment of the understanding of all aspects of any climate change over time, whether driven by natural variability or by human activity IPCC (2001). Thirty years later, the scientific consensus is that current climate change, an average global warming, is anthropogenically-driven, rapid and of large magnitude. The human population's daily life is already or will be imminently affected and "climate action" is now targeted as one of the Sustainable Development Goals by the United Nations.

Over the last decades our perception of our environment radically changed. The curiosity of scientists observing and trying to understand past climate variability has enabled contextualization of the current climate change within a long-term perspective. Over geological timescales, the Earth experienced large changes in global and regional climates. Multi-millennial time scale changes in orbital and greenhouse gas forcings during the Quaternary, for example, have produced several glacial and interglacial periods of different length and magnitudes (Hays et al., 1976; Masson-Delmotte et al., 2010; Milankovitch, 1941; Past Interglacials Working Group of PAGES, 2016; Yin and Berger, 2012). The current interglacial period, the Holocene, is part of the 100-ky world established since the Middle Pleistocene transition (1.25-0.7 Ma) and characterized by large amplitude glacial-interglacial oscillations occurring with a periodicity of 100 kyr (Clark et al., 2006). The Earth's climate also experienced decadal to millennial-scale variability (e.g. Fleitmann et al., 2009; Johnsen et 
al., 1992; Jouzel et al., 2007; Loulergue et al., 2008; McManus et al., 1999; Sánchez Goñi et al., 1999). Observing, modeling, and understanding processes and feedbacks that control those past climate changes are of critical importance for a better understanding of the nature, direction and magnitude of current climate change, its effect on life, and on the physical, biological, and chemical processes and ecosystem services essential for human well-being. Climate on Earth is conceptualized as a system where different spheres, i.e. the atmosphere, cryosphere, hydrosphere, lithosphere, biosphere, respond to external forcings, such as astronomical and anthropogenic forcing (Ruddiman, 2001). The anthroposphere is sometimes considered as a sphere of the climate system, and not as an external forcing (Cornell et al., 2012). The different spheres interact and depend on one another as an interconnected Earth system. Palaeoclimate studies not only aim at reconstructing the response of the atmosphere, but also of all different spheres as well as their interactions and related feedback mechanisms modulating climate changes. Climate models are necessarily now designed to include interactive coupled components that extend to all of these aspects of the Earth system. Vegetation, which is a major element of the biosphere, develops in response to climate and soil characteristics and plays an important role in the climate system. It is involved in vital ecosystem services such as nutrient and food production, mitigation of climate change, and soil and fresh water production and conservation (Faucon et al., 2017). Terrestrial plants act as a carbon sink and can limit the warming of atmospheric and ocean temperature by removing carbon from the atmosphere during the photosynthesis. Through the evapotranspiration process, plants also increase water vapor locally in the atmosphere, enhancing precipitation and cloud cover, which reinforces cooling. Changes in land cover further modify the albedo and act as a positive (warming) or negative (cooling) radiative forcing. Vegetation is therefore an integral part of the biogeochemical- and -physical processes between the land surface and the atmosphere (Foley et al., 2003). 
All ecosystems experience disturbances at different scales, and fire is one of the most widespread and severe disturbances in ecosystems globally, although it may maintain certain vegetation types, such as savanna (Bond et al., 2005). Fire is commonly found in intermediate environments in terms of climate, vegetation and demography, in all vegetation types (Harrison et al., 2010). Fire dynamics today result from the complex interplay between climate (precipitation and temperature controlling fuel flammability), vegetation (fuel type and load), ignition (lightning and human induced) and human fire suppression (Harrison et al., 2010). Fires have impacts on climate by modifying the carbon cycle and atmospheric chemistry, clouds, and albedo through the release of greenhouse gases and aerosols (Bowman et al., 2009; Lavorel et al., 2007).

Terrestrial plant-derived microfossils, preserved in terrestrial and marine sediments, such as pollen, microcharcoal and phytoliths, have greatly contributed to the present knowledge of the Quaternary vegetation and fire dynamics, and land-climate interactions. (Fig. 1). Pollen grains are part of the reproductive cycle of seed plants (angiosperms and gymnosperms); they are the male gametophyte, allowing for dissemination of the genetic material. Fossil pollen consists only of the external envelope, the exine, which is made of sporopollenin that is very resistant to decay. Microscopic charcoal (microcharcoal) is a carbonaceous material formed by pyrolysis, i.e. during the combustion process of vegetal elements (Jones et al., 1997). Phytoliths are opaline silica particles that precipitate in and/or between the cells of living plant tissues forming particular morphotypes. They are deposited in sediments when the plants die or burn.

Pollen, microcharcoal and phytoliths are studied from both terrestrial and marine archives. Terrestrial and marine sequences of plant-derived microfossils may give different but often complementary information due to the source vegetation area varying from local (peat, pond, small lakes) to regional (large lakes, ocean) and different associated transport processes. 
Deglacial and Holocene vegetation and fire changes have been extensively studied due to easier recovery of short cores and accessibility to recent sediments. For earlier time periods, terrestrial sequences become rarer and often suffer from discontinuities, involving chronostratigraphic complications that often hamper reliable reconstruction of past vegetation and climate changes. For instance, fragmentary Pleistocene sedimentary sequences are common in regions that have experienced the repeated expansions and retreats of the large northern hemisphere ice-sheets as in northern Europe and North America (de Beaulieu et al., 2013; Turner, 1998; Zagwijn, 1996), or glacier advances such as in New Guinea and New Zealand (Kershaw and van der Kaars, 2013). They are also common in arid and semiarid environments of Africa or Australia (Kershaw and van der Kaars, 2013; Meadows and Chase, 2013). The Pleistocene marine sedimentary archives in which terrestrial microfossils are studied, benefit in contrast from a continuous sedimentation. They are mostly located on continental margins from the shelf to the deep-sea, usually on seamounts so as to be free from turbidites, recruiting terrestrial microfossils produced by the vegetation of the nearby continent (Heusser, 1998). Marine records provide information on vegetation and fire changes at regional-scale on a chronology, beyond radiocarbon dating, that derives from stable oxygen isotope measurements on foraminifera enabling a reliable comparison with oceanic records (Heusser, 1998; Sánchez Goñi et al., 2018).

Since the beginning of the $20^{\text {th }}$ century, a large amount of palynological data was produced, revealing the major features of Pleistocene vegetation history and constituting the foundations of many basic concepts in Quaternary palaeoecology. For instance, in Europe and North America, where there is a long tradition in palynological research, pollen studies have played an important role for the understanding of Holocene vegetation history (Birks and Berglund, 2018; Davis, 1984) and climate. They have yielded important contributions to diverse biogeographical and palaeoecological topics such as continental-scale tree migrations 
(Huntley and Birks, 1983; Huntley and Webb, 1989) and biome dynamics after the end of the last Ice Age (e.g. Overpeck et al., 1992; Williams et al., 2004), the rates and magnitudes of species declines (e.g. Peglar, 1993) and vegetation response to interglacial climate changes (e.g. Turner and West, 1968; Zagwijn, 1994). Marine palynology greatly developed since Heusser's seminal works in the seventies (e.g. Heusser and Balsam, 1977; Heusser and Shackleton, 1979) bringing unique information on the phasing of the terrestrial and marine responses to orbital and millennial-scale climatic changes (Dupont, 2011; Sánchez Goñi et al., 2018).

Fossil microcharcoal preserved in terrestrial and lacustrine sediments has traditionally been counted during pollen analyses as a complementary proxy to vegetation since the eighties (Clark, 1982; Tolonen, 1986). It constitutes a powerful approach for reconstructing palaeofire histories over timeframes older than a few centuries as provided by remote sensing and by dendrochronological and historical records (Whitlock and Larsen, 2001). During the last decade, a significant increase in the number of palaeofire records and their regional or global syntheses has substantially improved our understanding of key drivers of fire under different climate conditions and of anthropogenic fire regime alteration (Daniau et al., 2012; Marlon et al., 2008; Vannière et al., 2011). Marine microcharcoal studies also developed relatively recently to address regional fire responses to orbital and millennial-scale climatic changes (Beaufort et al., 2003; Daniau et al., 2009; Daniau et al., 2013; Daniau et al., 2007). Palaeofire science has also led to new perspectives on long-term fire ecology paradigms (Aleman et al., 2018a).

Phytoliths were firstly described at the beginning of the $19^{\text {th }}$ century (Struve, 1835) and wellstudied in plant tissues (e.g. Prat, 1932) before being used as palaeoecological indicator in the sixties (Twiss et al., 1969). Interpretation of phytolith assemblages is far more complex than that of pollen assemblages due to imprecise correspondence between phytolith shapes and 
taxonomy. However, phytoliths, unlike pollen, present a high resistance to oxidation and therefore are well-preserved in arid environments. The increasing amount of modern reference collection from fresh terrestrial plants and soil assemblages enhanced archeological and palaeoenvironmental research from the eighties onwards (see Piperno, 2006). Today, fossil phytolith assemblages are much better-understood. Combined with a multi-proxy approach, they were recently used to discuss the evolution of grassland over the last million years in North America (Strömberg et al., 2013), the origin of the domestication of maize in Mexico (Piperno et al., 2009), or to examine the late Quaternary vegetation history of C3 and C4 grasses in East Africa (Montade et al., 2018). Phytoliths have also been studied from deepsea cores to document glacial-interglacial variations in aridity in tropical Africa (Parmenter and Folger, 1974; Pokras and Mix, 1985).

Here we present a review of how terrestrial plant microfossils are extracted from different sedimentary archives during laboratory processing, how they are identified and quantified, and how they can inform us about past environmental changes at different spatial and temporal scales necessary for understanding the Earth system (Fig. 1) focusing on continents from both hemispheres: Europe, Africa, North and South America.

Figure 1

\section{Microfossil concentrates and slide preparation}

Sample processing consists of a series of physical and chemical laboratory treatments in order to obtain clean slides of microfossil concentrates, i.e. a sufficient amount of microfossils that are observable under the microscope. The different chemical treatments are determined according to the composition of the sediments, typically consisting of calcium carbonates, 
organic matter and siliceous materials. Hydrochloric acid $(\mathrm{HCl})$ is used to remove calcium carbonates. A variety of chemical reagents are suited for organic matter removal, such as potassium hydroxide $(\mathrm{KOH})$, the acetolysis mixture consisting of acetic anhydride $\left(\left(\mathrm{CH}_{3} \mathrm{CO}\right)_{2} \mathrm{O}\right)$ and concentrated sulphuric acid $\left(\mathrm{H}_{2} \mathrm{SO}_{4}\right)$, hydrogen peroxide $\left(\mathrm{H}_{2} \mathrm{O}_{2}\right)$, or a mixture of nitric acid $\left(\mathrm{HNO}_{3}\right)$ with potassium chlorate $\left(\mathrm{KClO}_{3}\right)$. Hydrofluoric acid $(\mathrm{HF})$ is used to eliminate siliceous material, although use of this highly dangerous chemical can be substituted by a density separation process using much more benign sodium polytungstate.

\subsection{Pollen and spores}

Standard procedure for pollen extraction may include short boiling with potassium hydroxide $(10 \% \mathrm{KOH})$ for deflocculation and humic acid removal, cold diluted hydrochloric acid treatment $(10 \% \mathrm{HCl})$, to remove calcium carbonates $\left(\mathrm{CaCO}_{3}\right)$ and hydrofluoric acid $(30 \%$ to $70 \% \mathrm{HF}$ ) treatment to retrieve siliceous material (Faegri and Iversen, 1964; Moore et al., 1991). Acetolysis, with concentrated sulphuric acid and acetic anhydride, can also be performed after $\mathrm{KOH}$ digestion in particular in cellulose-rich material preparation such as peat deposits. Successive $\mathrm{HCl}$ digestions at higher concentrations $(25 \%, 50 \%)$ may be processed depending on the sample richness in $\mathrm{CaCO}_{3}$. It is recommended to use cold $\mathrm{HCl}$ since hot reagent can cause corrosion of the pollen wall (Moore et al., 1991). Traditionally, cold HF treatment for a long time (at least 24 hours) or hot HF for a few minutes has then been performed, followed by another $\mathrm{HCl}$ treatment to remove colloidal $\mathrm{SiO}_{2}$ and silicofluorides formed during the HF digestion. Alternatively, an inert heavy liquid such as sodium polytungstate solution can be used to remove siliceous material, rather than the highly dangerous (and expensive) HF (Campbell et al., 2016). This process works by preparing a solution of a specific gravity that is sufficiently dense to support the pollen, but allows the 
denser siliceous material to float to the bottom, allowing the pollen fraction to then be simply decanted off. Through a series of washes and filtering using a $5 \mu \mathrm{m}$ nylon mesh, it is also possible to reclaim the sodium polytungstate so that it can be reused. In addition, ultrasonic vibration can be used to disperse clays. A final sieving step using a $10 \mu \mathrm{m}$ nylon mesh screen that is particularly useful for removal of fine particles in clay-rich samples can end the extraction procedure. The use of $5 \mu \mathrm{m}$ filter is recommended for tropical pollen flora which includes grains of size below $10 \mu \mathrm{m}$.

To determine the sample pollen concentration, a tablet containing a known amount of exotic marker grains (commonly of Lycopodium spores) is added to the sample at the beginning of the preparation. The use of marker tablets has widely replaced other traditional volumetric and weighing methods used to establish pollen concentrations (Moore et al., 1991).

Pollen grains may be stained by adding drops of safranin or fuchsin to the residue with $\mathrm{KOH}$ during the final wash or directly into the mounting medium. Staining can help observation and identification under the microscope, although it is optional.

Residues obtained after pollen extraction are preferentially mounted in a mobile mounting medium such as glycerol or silicone oil since identification requires rotating the pollen grain for observation of the polar and equatorial views. Both mount types have side effects: glycerol makes the pollen swollen and slides with this media are quite short-lived while silicon oil requires an extra-step for dehydrating the residue before mounting (Andersen, 1960). If silicon oil does not influence pollen size, dehydrating agents such as ter-butanol (TBA) and the formerly used benzene do have an effect (Andersen, 1960; Meltsov et al., 2008). Glycerin jelly that does not allow pollen mobility is preferred for permanent slides such as modern pollen samples for reference collection, although like glycerol it has an influence on pollen size. Before mounting in glycerin jelly, excess water is removed by placing the tube upside down on a filter paper for a couple of hours or even a day. In contrast to silicon oil, glycerol 
and glycerin jelly require slide sealing usually done with histolaque LMR, paraffin or nail polish.

\subsection{Microcharcoal}

Charcoal is mostly composed of pure carbon formed at temperature between 200 and $600^{\circ} \mathrm{C}$ (Conedera et al., 2009). It is divided into two categories based on the size of the particles, microscopic (length $>10$ and $<100 \mu \mathrm{m}$ ) and macroscopic (length $>100$ or $125 \mu \mathrm{m}$ ) charcoal particles (Whitlock and Larsen, 2001). It is relatively resistant to chemical decomposition (classified as inertite) (Habib et al., 1994; Hart et al., 1994; Quénéa et al., 2006). Microbial decomposition is minimal (Hockaday et al., 2006; Verardo, 1997) especially if charcoal burial occurs in an environment with high sedimentation rate. Microscopic charcoal particles are commonly counted in the same slides used for pollen analyses in transmitted light. In this case, concentrates of microcharcoal are obtained following the standard procedure described in the pollen section (2.1.1) (Faegri and Iversen, 1964). No ultrasonic baths are used in order to avoid charcoal-particle breakage (Tinner and Hu, 2003). Rhodes (1998) proposed the extraction of microcharcoal from sediment samples using a dilute solution of hydrogen peroxide $(6 \%)$ for 48 hours at $50^{\circ} \mathrm{C}$ to bleach the dark organic component, followed by sieving at $11 \mu \mathrm{m}$ and another bleaching step. Reflected light (or incident light) has been used also during pollen slide analyses (Doyen et al., 2013) to secure the identification of microcharcoal from uncharred organic matter, although polished thin sections are generally more suitable for analyses using reflected light (Noël, 2001).

The protocol of Daniau et al. (2009) combines chemical treatments to concentrate microcharcoal and polished slides technique allowing both the particle observations in transmitted and reflected light. It has been developed on marine samples (Daniau et al., 2009) 
but has also been recently used for lake sediments (Inoue et al., 2018). It consists of concentrating microcharcoal particles by removing carbonates, silicates, pyrites, humic material, labile or less refractory organic matter (Clark, 1984; Winkler, 1985; Wolbach and Anders, 1989). This procedure bleaches organic matter and does not blacken unburned plant materials (Clark, 1984). The chemical treatment consists of successive chemical attacks by adding hydrochloric acid $(\mathrm{HCl})$, then cold or hot nitric acid $\left(\mathrm{HNO}_{3}\right)$ and hydrogen peroxide $\left(\mathrm{H}_{2} \mathrm{O}_{2}\right)$ on approximately $0.2 \mathrm{~g}$ of dried bulk sediment. A hydrofluoric acid (HF) step can be used, followed by rinsing with $\mathrm{HCl}$ to remove colloidal $\mathrm{SiO}_{2}$ and silicofluorides formed during the HF digestion, as in the pollen and spores protocol. A dilution of 0.1 is applied to the residue. The suspension is then filtered onto a membrane of $0.45 \mathrm{~mm}$ porosity. A portion of this membrane is mounted onto a slide before gentle polishing for observation under the microscope. The chemical treatment may be slightly modified, depending on the sample sediment composition.

Although this review focuses on microcharcoal, we briefly present laboratory analyses for macrocharcoal because the information used in many fire syntheses was obtained from studies using both macro- and microcharcoal records (see section 4.4 and fire discussion section). It is suggested, however, that macro- and microcharcoal records follow the same trends and thus display similar fire history patterns (Carcaillet et al., 2001). Macrocharcoal is extracted by using potassium hydroxide or sodium pyrophosphate solutions to remove humic acid and to disaggregate the sediment, followed by a dilute ( $4-6 \%$ only) hydrogen peroxide step and wet sieving through a $125 \mu \mathrm{m}$ sieve (Stevenson and Haberle, 2005).

\subsection{Phytoliths}

Phytolith extraction procedure from soil or lacustrine sediments consists of multiple steps following Aleman et al. (2013b). The sediments are deflocculated using a $5 \%$ weight solution 
of $\mathrm{NaPO}_{3}$ heated at $70{ }^{\circ} \mathrm{C}$, and shaken for twelve hours. Removal of carbonates, using a $1 \mathrm{~N}$ solution of $\mathrm{HCl}$ at $70{ }^{\circ} \mathrm{C}$ during one hour on a hot plate, is performed prior to the organic matter reduction as this step is more efficient in a slightly acid and non-calcareous environment (Pearsall, 2000). This step is also crucial to disperse the mineral fraction and prevent secondary reactions (Madella et al., 1998). Lake sediments are generally rich in organic matter which is removed by using $33 \% \mathrm{H}_{2} \mathrm{O}_{2}$ (Kelly, 1990; Lentfer and Boyd, 1998) at $70^{\circ} \mathrm{C}$ to accelerate the reaction to properly obtain cleaned slides for easier identification and counting. Alternatively, a mixture of nitric acid $\left(\mathrm{HNO}_{3}\right)$ with potassium chlorate (at a ratio of 1:3) heated for two hours at $90^{\circ} \mathrm{C}$ using glass material on a hot plate can be used to accelerate the reaction (Strömberg, 2002; Strömberg et al., 2018).

For lateritic sediments, removal of oxidized iron using tri-sodium citrate and sodium dithionite is recommended (Kelly, 1990). Another deflocculation, using $\mathrm{NaPO}_{3}$ at $70{ }^{\circ} \mathrm{C}$ (Lentfer and Boyd, 1998) shaken for 12 hours, then is required to remove clay efficiently since high clay concentration may affect data quality (Madella et al., 1998). Clay is removed by gravity sedimentation using 'low-speed' centrifugation to speed up the processing. Distilled water is added to the residue to a height of $7 \mathrm{~cm}$ and centrifuged for $1 \mathrm{~min} 30 \mathrm{~s}$ at $2000 \mathrm{rpm}$ (Stokes' law for particles $<2 \mu \mathrm{m}$, calculated for a Sigma Aldrich 3-16 centrifuge with an RCF.g of 769 at $2000 \mathrm{rpm}$ ). The step is repeated until the float is clear. Before performing densimetric separation of phytoliths, the residue is dried using ethanol to avert dilution of the dense liquor by the water contained in the residue.

The density of the heavy liquid is crucial for the densimetric separation step to prevent bias regarding phytolith selection, densities of which range from 1.5 to 2.3. Different heavy liquids can be used: $\mathrm{ZnBr}_{2} / \mathrm{HCl}$ solution adjusted to a relative density of 2.3-2.35 (Kelly, 1990) or, better, non-toxic sodium polytungstate ( $\mathrm{Na} 6[\mathrm{H} 2 \mathrm{~W} 12 \mathrm{O} 40])$. The density 2.3 of $1 \mathrm{~L}$ of dense liquor is obtained by mixing $1662 \mathrm{~g}$ of sodium polytungstate powder with $637 \mathrm{ml}$ of distilled 
water. The residue and the dense liquor are mixed and then centrifuged for two minutes at $3000 \mathrm{rpm}$. Disposable transfer pipets are used to suck the fine white layer floating on the dense liquor and transfer it to a $5 \mu \mathrm{m}$ PTFE filter (Kelly, 1990) mounted on a vacuum glass filtration holder. The dense liquor is recycled to reduce the costs of the extraction procedure and the environmental pollution. The floating residue on the filter is rinsed with $\mathrm{HCl}(1 \mathrm{~N})$ if $\mathrm{ZnBr}_{2}$ is used, and distilled water; otherwise the supernatant is only washed with distilled water. The phytoliths are transferred to a vial and an exotic marker is added (a lycopodium tablet or silica microspheres (Aleman et al., 2013b)). The samples are decanted for twelve hours and then dried in a drying oven if silica microspheres are used; otherwise naturally dried by evaporation. The residue is preserved in ethanol or glycerin.

\section{Identification, counting and digital image processing of terrestrial plant microfossils}

\subsection{Pollen and spores}

Microscopic observation of the pollen of flowering plants and gymnosperms and spores of pteridophytes allows identification with a taxonomical resolution rarely reaching the specific level but more often the family or genus levels and sometimes a group of species within a genus (Jackson and Booth, 2007). The identified grains are allocated to a morphotype (or pollen taxa) based on various features related to the size and shape of the grain, to the shape, number and distribution of the apertures/scars and to the structure and ornamentation of the pollen/spore wall (Fig. 2). A large literature describes these features although the associated terminology varies depending on the authors (Erdtman, 1954; Faegri and Iversen, 1964; Hesse et al., 2009; Kapp's, 2000; Moore et al., 1991; Reistma, 1969). We only report hereafter the main characteristics used for identification (see above references for further details), mainly 
with the terminology used in Moore et al. (1991). The descriptive terminology can be bewildering for the novice but provides an essential basis for accurate description, comparison and identification of morphotypes; a valuable illustrated glossary is provided by Punt et al. (2007).

Pollen size varies mostly between 15 and $100 \mu \mathrm{m}$ although some grains can be as large as 140 $\mu \mathrm{m}$ such as Malvaceae pollen or slightly less than $10 \mu \mathrm{m}$ such as pollen from tropical and subtropical trees and shrubs, like Elaeocarpus and Cecropia. The shape of a pollen grain generally varies from spherical to elliptical, either oblate when the polar axis is shorter than the equatorial axis or prolate for the reverse. An aperture is a thin area or a missing part of the exine, either circular to elliptical (porus or pore) or elongated (colpus or furrow), that allow the germination of the pollen tubes for plant reproduction. The shape, number and arrangement of the apertures constitute a primary criterion for identification of pollen types. Type names include the terms porate, colpate or colporate describing the aperture shape with a prefix (mono-, di-, tri-, tetra-, penta-, hexa- and poly-) defining the aperture number. It is possible to find grains without apertures, corresponding to the inaperturate pollen type. Another prefix describing the aperture arrangement can also be added: zono- and panto-, following Erdtman (1954) and Moore et al. (1991) or stephano- and peri- following Faegri and Iversen (1964) for apertures distributed in the equatorial zone or all over the surface of the grain, respectively. The structure and sculptures of the pollen wall present a large variability constituting precious criteria for the identification of the pollen grains. The fossil pollen wall of angiosperms, namely the exine, is composed of a homogenous inner layer, the endexine, and a complex outer layer, the ectexine, which may include a foot layer, with above radial rods, named columellae, supporting a tectum with various supratectatal sculpturing elements (bacula, clavae, echinae, pila, gemmae, verrucae, scabrae or granules). All layers may be continuous, discontinuous or absent, may present particular thickening features such 
as arcus or annuli (cf. Alnus and Poaceae pollen grains). When there is no tectum (intectate grain as opposed to tectate grain), sculpturing elements may be found on the top of the foot layer. Columellae can also be partially joined at their heads; the grain is described in this case as semitectate. The arrangement of the columellae or of the supratectal sculpturing elements or their fusion in elongated elements can give rise to a network (reticulum) or striations. The gymnosperm pollen wall differs slightly: the endexine is lamellate and the ectexine never has columellae but alveoli or granula (Hesse et al., 2009). Pinaceae and Podocarpaceae pollen grains display a special feature: the air sacs (sacci).

Pteridophyte spores have the same size range but depart from pollen for the presence of monolete and trilete scars and a simpler wall structure, although it can be multilayered and ornamented (Kapp's, 2000).

Figure 2

An exhaustive list of pollen atlases is referenced in Hooghiemstra and van Geel (1998). Pollen atlases published since 1998 are reported in Table 1. In addition, an initiative has been developed to aid the identification of pollen grains, and provide virtual access to reference material at https://globalpollenproject.org/ (Martin and Harvey, 2017).

\begin{tabular}{|l|l|}
\hline Region & Reference \\
\hline Europe & Beug (2004) \\
\hline Africa & $\begin{array}{l}\text { Schüler and Hemp (2016) } \\
\text { Scott (1982) } \\
\text { Gosling et al. (2013) }\end{array}$ \\
\hline Asia & $\begin{array}{l}\text { For Japan: Demske et al. (2013) } \\
\text { For Indonesia: Jones and Pearce (2014) } \\
\text { For India: Kailas et al. (2016); Mudavath et al. (2017) }\end{array}$ \\
\hline
\end{tabular}




\begin{tabular}{|l|l|}
\hline & For China: Fujiki et al. (2005); (Yang et al., 2015) \\
\hline North America & Kapp's (2000); (Willard et al., 2004) \\
\hline $\begin{array}{l}\text { Central and } \\
\text { South America }\end{array}$ & $\begin{array}{l}\text { For the whole Neotropics, freeware online database: Bush and Weng } \\
\text { (2007) } \\
\text { For Amazonian taxa: Colinvaux et al. (1999) } \\
\text { For Paramo and high elevation Andean taxa: Velasquez (1999) } \\
\text { For Brazil: Cassino and Meyer (2011) } \\
\text { For Venezuela: Leal et al. (2011) } \\
\text { For Atlantic forest: Lorente et al. (2017) }\end{array}$ \\
\hline
\end{tabular}

Table 1. List of pollen atlases for different regions of the world available for pollen grains identification (not referenced in Hooghiemstra and van Geel (1998)).

Counting is routinely done with a light microscope at 400x although use of an oil immersion objective allowing 1000x magnification is required in some cases (Birks and Birks, 1980). The number of pollen grains and spores counted varies depending on the research objectives although it should be enough high to reach constant percentages of the different taxa and at least exceed a minimum count of 100 to calculate the relative proportions (expressed as percentages of the pollen sum). For terrestrial sediments, 300 to 500 grains are usually counted (Birks and Birks, 1980). For marine sediments, counting usually aims to reach a total of 300 pollen and spore grains with at least 100 pollen grains excluding Pinus, a well-known over-represented taxon (Desprat, 2005; Turon, 1984). At least 20 taxa are usually identified to provide a representative image of the composition and diversity of the European or North American vegetation (McAndrew and King, 1976; Rull, 1987). In tropical regions where the taxa diversity is far more important and largely variable, saturation curves can be used to determine the number of grains that have to be counted to reach a plateau in the number of taxa found (Birks and Birks, 1980). 


\subsection{Microcharcoal}

Microcharcoal is identified microscopically in transmitted light as debris that is black, opaque, and with sharp edges, according to criteria from Boulter (1994) (Fig. 3). Petrographic criteria in reflected light include visible plant structures characterised by thin cell walls and empty cellular cavities, or particles without plant structure but of similar reflectance than the previous ones (Noël, 2001).

Originally, both the number and area of microcharcoal fragments were analysed in pollen slides. The area of microcharcoal was estimated using tedious methods, the square eye-piece grid method (Swain, 1973) or the point-count method (Clark, 1982). Concentrations of microcharcoal fragments and areas are highly positively correlated (Tinner and $\mathrm{Hu}, 2003$ ). It was therefore suggested avoiding the quantification of microcharcoal areas because it was time consuming for gaining little additional information compared to a simple counting of microcharcoal fragments. Counting microcharcoal on pollen slides is currently performed at 200x or 500x magnification (Doyen et al., 2013; Morales-Molino et al., 2011) by counting only the number of microcharcoal in pollen slide (Tinner and $\mathrm{Hu}, 2003$ ) with a minimum of two hundred items (the sum of charcoal and exotic marker grains) (Finsinger and Tinner, 2005).

More recently, some studies indicated that fragmentation of charcoal particles may occur during taphonomical processes (Crawford and Belcher, 2014; Leys et al., 2013). This potential fragmentation may lead to an overrepresentation of microcharcoal, i.e. a virtual increase of the number of fragments per gram, while this increase would not have been seen in the total area concentration (see below for an explanation of the two concentrations). Using the total area helps therefore interpreting charcoal fragment concentration. Counting and area measurement of individual charcoal particles is recommended further because it provides an 
opportunity to link both particle counts and particle areas to different metrics of fires, such as burned area, fire number, fire intensity or fire emissions (Adolf et al., 2018b; Hawthorne et al., 2018).

Digital image processing can be used to generate microcharcoal data more efficiently and to conduct morphological particle analyses. Image analysis can be carried out in software such as Image J (open source) (Abramoff et al., 2004) which can be used to measure the individual area of each particle, total area of all particles and the number of particles that are observed in each microscopic field (Beaufort et al., 2003; Daniau et al., 2009; Doyen et al., 2013; Inoue et al., 2018; Thevenon et al., 2004). The shape is studied using the length, width and the elongation measurements.

Automated image analysis consists of scanning the slides in a controlled light adjustment (transmitted light) to detect and measure microcharcoal using a threshold value in red, green and blue (RGB), or in tint, saturation and lightness (TSL) color space (see for example Daniau et al., 2009). Automated scanning of the slides requires the microscope to be equipped with a stage motorized in the $\mathrm{X}, \mathrm{Y}$ and $\mathrm{Z}$ axes. Moving on the $\mathrm{X}$ and $\mathrm{Y}$ axes permits to scan different separate fields of the slide ( 150 or 200 images with a pixels digitising camera to provide reproducible results, Beaufort et al., 2003; Daniau et al., 2007; Doyen et al., 2013). The Z-axis permits to adapt the focus for each field. Observations and automated image analysis is performed in general at 400x (Doyen et al., 2013) or 500x magnification (Daniau et al., 2009; Inoue et al., 2018). Identification of uncharred organic matter (in reflected light, using oil immersion), characterized by the absence of plant structures and distinct level of reflectance, can be used to set the best-fit threshold level to secure identification of microcharcoal by image analysis.

From these measurements, two types of concentration per gram of dry bulk sediment are calculated, i.e. the number of fragments of microcharcoal (fragments, \#/g) and the total area 
of microcharcoal $\left(\mathrm{mm}^{2}\right.$ or $\left.\mu \mathrm{m}^{2} / \mathrm{g}\right)$. When the density or the volume of the treated sediment is known, concentrations are expressed per volume $\left(\mathrm{cm}^{3}\right)$. The total area corresponds to the sum of the individual areas of microcharcoal. The shape is studied using the elongation ratio (or aspect ratio) expressed as the ratio Length on Width (Crawford and Belcher, 2014; Umbanhowar and McGrath, 1998); or as the ratio Width on Length (Aleman et al., 2013a).

Figure 3

\subsection{Phytoliths}

The recovered phytolith fraction from the extraction procedure is mounted on microscope slides using mobile mounting medium, glycerin or immersion oil, to allow the rotation of phytolith for observation. Phytoliths are counted at 400x or 600x magnification. Immersion oil may be preferred as mounting media to facilitate observation because phytolith show a better contrast under the microscope rather than by using glycerin. Phytoliths are amorphous silicate and are distinguishable from quartz grains using a polarizing filter on the microscope. Other siliceous components can be diatoms, freshwater sponge spicules or siliceous protozoans such as testate amoebae (Rhizopoda). Diatoms, or even parts of valves, are easily distinguishable from phytoliths via finer ornamentations compared to phytoliths. Sponge spicules are generally needle-like in form and are either smooth or spined. They are visually distinguishable from phytoliths because their surfaces are generally smooth and the purity of the silicate makes it translucent. Finally, testate amoebas are recognizable when they are entire, but the tests are composed of siliceous plates that may be disarticulated during taphonomic processes or lab treatments. These plates have round to square shapes and usually 
measure between 5 to $15 \mu \mathrm{m}$. Rounded curved plates can be confused with microspheres. In this case rotation of the particle is needed for identification.

During the counting procedure, sufficient items (exotic marker and the most frequent phytolith morphotype with taxonomic significance) should be counted to reach an estimate of the total phytolith concentration with a precision of at least $\pm 15 \%$, as described in (Aleman et al., 2013b). In general, this consists in counting at least 300 phytoliths of morphotypes with taxonomic significance per sample and with size greater than $5 \mu \mathrm{m}$.

Description of phytolith morphotypes should be done according to their three-dimensional shape and classification should follow the International Code for Phytolith Nomenclature (ICPN; Madella et al. (2005)). The ICPN was developed in order to use a standard protocol to name and describe new phytoliths, and to provide a glossary of descriptors for phytoliths. As such, when describing a phytolith type the following information are necessary: 1) description of the shape (3D and 2D), 2) description of the texture and/or ornamentation, and 3) symmetrical features. Other information can also be provided when possible (e.g. morphometric data, illustrations and anatomical origin, Madella et al. (2005)). Because of redundancy and multiplicity in phytolith shape (Fredlund and Tieszen, 1994; Mulholland, 1989; Rovner, 1971), one phytolith type can rarely be related to one plant taxon and therefore in order to use this vegetation proxy, the whole phytolith assemblage must be considered. Past tree cover, aridity/humidity changes and plant water stress can be assessed by grouping morphotypes into specific indices. In addition, phytoliths from the Poaceae family produce peculiar morphotypes that provide information about past grass dynamics and evolution (Strömberg, 2002).

In general, phytolith morphotypes are grouped into five large categories (Fig. 4):

Figure 4 
1. Grass silica short cells (GSSC) are produced by Poaceae (Mulholland and Rapp, 1992). Among the GSSCs, the bilobates (a), polylobates and crosses (b) are mainly produced by the Panicoideae subfamily (Fredlund and Tieszen, 1994; Kondo et al., 1994; Mulholland, 1989; Twiss et al., 1969) which is C4 grasses adapted to warm and humid climate. The saddle (c) type occurs dominantly in the Chloridoideae subfamily (Fredlund and Tieszen, 1994; Kondo et al., 1994; Mulholland, 1989; Twiss et al., 1969), C4 grasses adapted to a warm and dry climate. The rondel type (d), corresponding to the pooid type defined by Twiss et al. (1969) and the conical, keeled and pyramidal types (e) from Fredlund and Tieszen (1994), include conical, conical bilobate (f), conical trilobate and conical quadrilobate morphotypes. The trapeziform short cell type (Fredlund and Tieszen, 1994; Kondo et al., 1994; Mulholland, 1989; Twiss et al., 1969) comprises trapeziform, trapeziform bilobate (g), trapeziform trilobate (h) and trapeziform quadrilobate morphotypes. The rondel and trapeziform short cell types are preferentially produced by the Pooideae subfamily (C3, high elevation grasses), but also by the other subfamilies (Barboni and Bremond, 2009). Zea mays produces a particular cross type, and using morphometric analysis it is possible to precisely identify its presence in archeological records (Piperno, 2006). Bambusoideae grasses produce Bilobate and Saddle short-cells and some genus produce distinct phytolith types such as Chusquoid body or collapsed saddles in Chusquea (Piperno and Pearsall, 1998).

2. The bulliform cells category relates to cell morphology trackers that can be identified. For example, epidermal cells have been calibrated to reconstruct leaf area index (LAI) (Dunn et al., 2015). Bulliform cells (i) from the leaves of Poaceae are used as a proxy of aridity (Bremond et al., 2008).

3. The woody dicotyledon category is composed of globular granulate (j) (Alexandre et al., 1997; Bremond et al., 2005a; Kondo et al., 1994; Scurfield et al., 1974), globular decorated 
(k) (Neumann et al., 2009; Novello et al., 2012; Piperno, 2006; Runge, 1999), sclereid (Mercader et al., 2000; Neumann et al., 2009; Runge, 1999), blocky faceted (1) (Mercader et al., 2009; Neumann et al., 2009; Runge, 1999) and blocky granulate morphotypes (Mercader et al., 2009).

4. The other family-specific morphotypes are composed of morphotypes that can be attributed to specific families. Papillae types (m) (Albert et al., 2006; Gu et al., 2008; Novello et al., 2012; Runge, 1999) are produced by Cyperaceae (Kondo et al., 1994) that mainly grow in wetlands. The globular echinate morphotype (n) is produced by palms (Arecaceae) (Kondo et al., 1994; Runge, 1999). Phytoliths of Musa are volcaniform (o) (Ball et al., 2016) when the ones from Cucurbita are spheroidal or hemispheroidal with deeply scalloped surfaces of contiguous concavities (Piperno et al., 2000). Other specific phytoliths can be attributed to rice, Maize or Marantaceae (see the exhaustive discussion in Piperno (2006)).

5. Non-diagnostic morphotypes (p) such as globular smooth, elongated or tabular and blocky types are sometimes attributed to specific vegetation types, such as closed environments. However, the diversity of shapes behind the generic terms makes it difficult to be exhaustive for this category (see Garnier et al., 2012; Novello et al., 2012; Runge, 1999).

Comprehensive databases and atlases for phytolith identification do not exist yet. The web and scientific papers provide some atlases but the data are diverse, dispersed and not easily comparable. The data are presented generally by taxon (Family, Genus or Species) or by phytolith morphotypes. Modern phytolith assemblages have been extensively studied in Africa (Barboni et al., 2007). The PhytCore DB (http://www.phytcore.org) provides modern phytolith assemblages but it is very oriented for archeological studies. It is therefore important analysing modern soil or recent sediment samples in the surrounding vegetation types of the 
"fossil" studied area. Here, we provide a non-exhaustive list of different phytolith atlases available on the web (Table 2).

\begin{tabular}{|l|l|}
\hline Name & Website link \\
\hline $\begin{array}{l}\text { PhytCore (Archeological sites from Spain, East } \\
\text { and South Africa) }\end{array}$ & $\underline{\text { http://www.archeoscience.com/ }}$ \\
\hline $\begin{array}{l}\text { The University of Missouri Online Phytolith } \\
\text { Database (essentially the flora of Ecuador) }\end{array}$ & $\underline{\text { http://phytolith.missouri.edu/ }}$ \\
\hline $\begin{array}{l}\text { Paleobot (collaborative, open-access web } \\
\text { resource for scientists and scholars engaged in } \\
\text { palaeobotanical research) }\end{array}$ & $\underline{\text { http://www.paleobot.org/ }}$ \\
\hline Old World reference phytoliths & $\underline{\text { http://www.homepages.ucl.ac.uk/ tcrndf }}$ \\
\hline The Blinnytoliths.html \\
\hline
\end{tabular}

Table 2: List of phytolith atlases available online.

\section{Terrestrial plant microfossils for qualitative and quantitative environmental reconstructions}

\subsection{Information from pollen}

\subsubsection{Environmental information}

Fossil pollen assemblages are widely used for reconstructing past vegetation composition and distribution, and thereby climate and land-use changes. Pollen analysis is based on a set of principles that allow the pollen assemblage found in sedimentary archives to be related to the surrounding vegetation (e.g. Birks and Birks, 1980; Prentice, 1988). Information on the 
pollen-vegetation relationship in particular is derived from the extensive study of surface (modern) pollen samples, taken in defined vegetation units characterizing an ecosystem or a bioclimate, as well as in various sedimentary contexts. Modern pollen rain-vegetation relationships were therefore investigated in a wide variety of landscapes worldwide, although some regions are still under-studied, such as arid and semiarid environments. From these studies arose several regional modern pollen databases for Europe (Davis et al., 2013; Fyfe et al., 2009), North America (Whitmore et al., 2005), East Asia (Zheng et al., 2014), Africa (Gajewski et al., 2002) and South America (Flantua et al., 2015).

Surface sample studies have shown there is no linear relationship between pollen proportions and plants abundances. Pollen proportions from a sedimentary archive give qualitative information on changes in vegetation composition through time and over a spatial area. Many studies demonstrated that pollen assemblages clearly discriminate between vegetation formations or forest-types and that pollen proportions of the major taxa reflect their relative importance in the vegetation (Prentice, 1988). Individual calibration studies prior to the analysis of a sedimentary archive are recommended to provide the characterization of the relationship between the pollen rain and local and regional vegetation essential to interpret the fossil pollen records in terms of vegetation changes. For example, in Southern Africa, Poaceae percentages were demonstrated to be critical to distinguish the pollen signal of the major biomes and associated climatic zones (Urrego et al., 2015). In the Mediterranean region, pollen assemblages within degraded maquis, for instance, appear largely influenced by adjacent land-covers such as conifer woodland and open vegetation (Gaceur et al., 2017).

A large literature aims at understanding and estimating the factors that determine the source vegetation and modifies the pollen representativeness in terms of vegetation composition and abundance (e.g. Broström et al., 2008; Bunting et al., 2013; Gaillard et al., 2008; Havinga, 1984; Prentice, 1985; Sugita, 1994; Traverse, 2007). The differential pollen production, 
dispersal and preservation between pollen taxa lead to the over- or under-representation of some morphotypes. The long-distance transport of anemophilous taxa is a common factor biasing the representation of the local vegetation by pollen assemblages (e.g. Traverse, 2007). This is particularly true in mountain regions where wind drives uphill transport of tree pollen (Ortu et al., 2006). The most widely known example is the over-representation of Pinus pollen that produces a large quantity of highly buoyant saccate pollen.

The structure and composition of the surrounding vegetation affect the source area of pollen. For instance, pollen rain in an open landscape is prone to increased contribution of pollen originating from distant vegetation (Bunting et al., 2004). The size (i.e. few meters to kilometers) and type (e.g. bogs, mires, lakes and ocean) of the sampling site also influence the pollen source area from local to regional inputs (e.g. Prentice, 1985; Sugita, 1994; Traverse, 2007). Ponds and small lakes mostly receive pollen from the vegetation surrounding the sampling site and therefore represent more local estimates of vegetation than large lakes (in their centers) that collect predominantly wind-transported pollen from the regional vegetation background (e.g. Sugita, 1994, 2007a, b). Note that without using specific pollen-based modelling approaches (see section 4.1.2) the dissociation between local and regional pollen signals cannot be assessed. Pollen studies on modern marine surface sediments showed that pollen assemblages reflect an integrated image of the regional vegetation of the adjacent continent (e.g. Heusser, 1983; Naughton et al., 2007). Such studies revealed that pollen grains are mainly transported to the ocean realm by wind and rivers but the role of these transport agents depends essentially on the environmental conditions of each area (e.g. Dupont et al., 2000; Groot and Groot, 1966). Pollen is predominantly supplied to the ocean by fluvial transport, in regions where hydrographic systems are well-developed such as in the western Iberian margin, northern Angola basin, western North Atlantic margin and in the Adriatic Sea (e.g. Bottema and van Straaten, 1966; Dupont and Wyputta, 2003; Heusser, 1983; Naughton 
et al., 2007). In arid zones, such as northwest Africa, with weak hydrological systems and strong winds, pollen are mainly wind-blown (e.g. Hooghiemstra et al., 2006; Rossignol-Strick and Duzer, 1979). A mixture of fluvial and wind pollen transport may also occur as shown in the Gulf of Guinea (Lézine and Vergnaud-Grazzini, 1993) and the Alboran Sea (Moreno et al., 2002). Once in the ocean, pollen grains sink rapidly through the water column thanks to processes decreasing its buoyancy such as agglomeration (taking part to the marine snow), flocculation and incorporation in fecal pellets (Mudie and McCarthy, 2006) and thereby preventing long-distance transport by marine currents (Hooghiemstra et al., 1992).

\subsubsection{Pollen-based land cover reconstruction}

Pollen assemblages extracted from terrestrial sedimentary cores reflect a mix of both local and regional vegetation, and this makes difficult the assessment of quantitative vegetation reconstruction based on pollen proportions. Correction factors were proposed as early as the fifties to minimize biases in the representativeness of pollen assemblages (see Birks and Berglund (2018) and references therein). From the eighties, important methodological improvements took place with the development of models taking into account the differential production and dispersal of pollen, and the size and type of the sedimentary basin (e.g. Prentice and Parsons, 1983; Sugita, 1993, 1994, 2007a, b). These models have resulted in the development of the Landscape Reconstruction Algorithm (LRA, Sugita, 2007b) for quantitative reconstruction of past vegetation composition.

The LRA approach corresponds to two sub-models, REVEALS (Regional Estimates of Vegetation Abundance for Large Sites, Sugita, 2007a) and LOVE (Local Vegetation Estimate, Sugita, 2007b). REVEALS reconstructs the regional vegetation composition in a radius of ca. $50 \mathrm{~km}$ using pollen counts from large lakes ( $>50 \mathrm{ha}$ ). REVEALS can also be 
used for a combination of small and large lakes and bogs, although the standard errors would be greater than when using for a large lake only (Marquer et al., 2017; Trondman et al., 2016). LOVE reconstructs the local vegetation composition in a radius of few meters to kilometers that corresponds to the relevant source area of pollen (RSAP). To calculate quantitative estimates of local vegetation composition, LOVE uses pollen counts from small sites (lakes and bogs $<50 \mathrm{ha}$ ) and subtracts the regional background of pollen using REVEALS estimates(i.e. pollen coming from beyond the RSAP) . LOVE estimates represent the local vegetation composition within the RSAP. The LRA models incorporate critical parameters to correct the non-linear relationships between pollen percentages and plant abundances, e.g. pollen productivity estimates of specific plant taxa, fall speed of pollen and basin size, and several assumptions, e.g. specific wind speed and characteristics of atmospheric conditions. Current model improvements correspond to the implementation of an alternative pollen dispersal model in the LRA approach (e.g. Theuerkauf et al., 2016; Sugita, unpublished). The REVEALS and LOVE models are now increasingly applied to provide quantitative reconstructions of the Holocene vegetation composition from local, regional to subcontinental spatial scales (e.g. Cui et al., 2014; Fyfe et al., 2013; Hellman et al., 2008a; Hellman et al., 2008b; Marquer et al., 2017; Marquer et al., 2014; Mazier et al., 2015; Nielsen et al., 2012; Nielsen and Odgaard, 2010; Overballe-Petersen et al., 2013; Soepboer et al., 2010; Sugita et al., 2010; Trondman et al., 2015; Trondman et al., 2016). The REVEALS model has largely been used for pollen-based land cover reconstruction in Europe and it is now applied to other regions (essentially in the northern hemisphere) via the support of the PAGES LandCover6k initiative (Gaillard et al., 2018). Evaluation of the LRA models reliability in the southern hemisphere and tropics (Southern Asia, Central Africa and South America) is in progress. 
Contrary to the MAT method, the REVEALS approach requires some a priori information (i.e. explicit assumptions) on pollen productivity estimates (PPEs), lake size and wind speed. PPEs are difficult to estimate and time and resource consuming considering that taxon pollen productivity presents a high regional and interannual variability. Since all these parameters may vary through time, treating them as known processes increases the uncertainties of REVEALS land-cover reconstructions. However, REVEALS remains the only method that addresses these uncertainties directly, and at the taxon level. In addition, there are also subtle differences in the nature of the land-cover reconstruction between methods. For instance, REVEALS reconstructs the proportion of the land cover occupied by taxa in the landscape, irrespective of their physical size. In contrast, MAT methods often have a specific physical definition associated with the remote sensing datasets that are used for calibration, such as a minimum height (e.g. greater than $5 \mathrm{~m}$ ) for forest taxa. This has implications in, for instance, shrub dominated landscapes such as forest-tundra landscapes where REVEALS may indicate more "forest" than MAT due to the low physical stature of the taxa (Zanon et al., 2018). An alternative and less resource intense approach has been developed by Williams (2003), based on the popular modern analogue technique (MAT) applied in pollen-climate reconstructions, whereby analogues of fossil pollen samples are found in a modern pollen database. In the land-cover reconstruction method, the fossil sample is assigned to the remotesensing derived forest cover of the closest matching modern pollen sample site.

This method is particularly useful to reconstruct past forest cover at continental scales. It was used to reconstruct Holocene forest cover in North America (Williams, 2003), Europe (Zanon et al., 2018), Northern Eurasia (Tarasov et al., 2007), and time slices for the whole of the northern hemisphere mid and high latitudes (Williams et al., 2011).

Zanon et al. (2018) showed that both methods generally provide comparable results. However, the MAT systematically estimates lower forest cover than REVEALS although this 
offset reduces in some pioneer vegetation landscapes. This discrepancy may be due to different definitions of 'forest cover' between the two methods, with trees greater than $5 \mathrm{~m}$ in the case of MAT, whereas forest is simply defined as the proportion of forest forming taxa irrespective of their size in REVEALS.

Other semi-quantitative methods for reconstructing land-cover are based on the 'biomisation' method (Prentice et al., 1996). This essentially compensates for differing pollen productivity and dispersion by transforming pollen percentages data using the square-root method. This has the effect of de-emphasising the taxa which represent the larger proportions (often the trees) and emphasizing more the taxa with the smaller proportions (often the herbaceous taxa). Taxa are then grouped according to common plant functional types (PFT's) grouped in turn into biomes. The sum of the square rooted percentages of each group of taxa represents its 'score'. The highest 'score' represents the vegetation biome of the pollen sample assemblage. Biomisation classification schemes have been developed for almost all regions of the world (Prentice and Jolly, 2000). The original motivation for this work was the evaluation of climate model simulations through forward modelling. This side-steps the problems associated with pollen-climate based data-model comparisons (see section 4.1.3) because the vegetation represented by the pollen record is directly compared with the vegetation generated by a process based vegetation model fed with output from the climate model simulation (Prentice et al., 1998). This approach has many advantages, not least the ability to take into account the complex response of vegetation to many different aspects of climate, such as temperature, precipitation, seasonality, cloudiness and frost frequency. Unfortunately, one of the main disadvantages is the difficulty in aligning the vegetation generated by the vegetation model with that represented by the pollen record. For instance, the link between the original biome vegetation model and pollen biomisation classification schemes (Prentice et al., 1996) is based on the unproven assumption that modelled Net Primary Productivity (NPP) is 
directly linked to pollen percentages. Similarly, because the model generates potential natural vegetation, and the pollen data reflects actual vegetation, it becomes difficult to judge the accuracy of a pollen biomisation scheme with, for instance, over eight different schemes available in Europe alone (Allen et al., 2010; Allen et al., 2000; Bigelow et al., 2003; Binney et al., 2017; Marinova et al., 2018; Peyron et al., 1998; Prentice et al., 1996; Tarasov et al., 1998).

However, considering the simplicity of the approach, the biomisation procedure nevertheless proved to work remarkably well in many regions at continental scales. While the original procedure was developed specifically to reconstruct the natural potential vegetation, the procedure has also been adapted to reconstruct human impacted landscapes, the pseudobiomisation approach (Fyfe et al., 2010). It was used to reconstruct the land-use and forest cover of Europe throughout the Holocene (Fyfe et al., 2015). Roberts et al. (2018) showed that the three methods, pseudo-biomisation, REVEALS and biomisation approaches, captured the basic trend in forest cover change over Europe during the Holocene.

Biomisation, pseudo-biomisation and modern analog technique can be used at continental and global scales and provide semi-quantitative estimates for biomes, plant functional types, land cover classes and tree covers, when LRA provides quantitative estimates of the cover of plant taxa at specific spatial scales, i.e. from local, regional to continental scales. Those quantitative estimates of vegetation are critical to i) evaluate climate and human-induced changes in vegetation composition and diversity, ii) answer archaeological questions about land use, iii) inform strategies related to conservation of natural resources and iv) be used as inputs for climate and dynamic vegetation modelling (e.g. Cui et al., 2014; Gaillard et al., 2010; Marquer et al., 2018; Marquer et al., 2017; Mazier et al., 2015).

\subsubsection{Pollen-based climate reconstruction}


Fossil pollen data have been used for quantitative reconstructions of past climate for over 70 years (Iversen, 1944). Pollen remains the main terrestrial proxy used for continental-scale evaluation of climate model simulations as part of the Paleo-climate Model Intercomparison Project (PMIP) for key time periods of the last climatic cycle (126, 21 and $6 \mathrm{ka})$ (OttoBliesner et al., 2017), and as far back as the mid-Pliocene (3.0-3.3 Ma) under the Pliocene Model Intercomparison Project (PlioMIP) (Haywood et al., 2013). Those models are used to simulate future climate and their palaeo-climate evaluations provide the only real test of reliability outside of our modern climatic experience. Palaeo-climate reconstructions have been based on widely spaced time-slices. It becomes possible now to produce spatially explicit continuous reconstructions through time in data rich regions such as Europe (Davis et al., 2003b; Mauri et al., 2015) and North America (Viau and Gajewski, 2009). Spatially explicit reconstructions allow us to view the spatial structure of climate change, much of which is driven by change in atmospheric circulation which appears to be under-estimated in climate models (Mauri et al., 2014). The high spatial variability indicated by pollen synthesis studies (and others, see de Vernal and Hillaire-Marcel, 2006; Kaufman et al., 2004) suggests strong sampling bias in regional or even global interpretations from one or very few sites (Hansen et al., 2006; Marcott et al., 2013). Large networks of pollen sites allow area-average estimates that reflect more accurately climate system energy-balances. They are also more comparable with climate models with their large grid box resolutions (Bartlein et al., 2011). The main advantage of pollen data is its almost unrivalled spatial coverage from virtually all terrestrial regions of the Earth, together with the wide range of seasonal and annual climate parameters that can be commonly reconstructed. Disadvantages include relatively low centennial-scale temporal resolution (especially when multiple records are combined at large spatial scales), and the possibility that non-climatic environmental factors may also influence 
the vegetation record through disease, succession, migration lag, soils and human action (Mauri et al., 2015). Another issue is the no-analogue-vegetation problem (Jackson and Overpeck, 2000; Williams et al., 2001), i.e. unique associations of taxa in the past that do not occur today, such as during the rapid post-glacial re-colonisation of higher mid-latitudes following the retreat of LGM ice sheets. This problem is also related to the no-analogueclimate problem, when there is no modern analogue for a climate in the past, such as the particular combination of seasonal insolation during the last Interglacial, or the low $\mathrm{CO}_{2}$ concentration during the LGM. It should be noted that the problem of human action on vegetation is often the inverse of how it is popularly conceived, since most transfer functions are assessed and calibrated for the present day when human action has probably been at its highest. It is in fact a lack of human action in the past that can create a no-modern-analogue problem for the transfer function.

Since the first pollen-climate transfer function over 70 years ago, there has been a large number of different methods developed, largely motivated by the problems that we have already outlined. These methods can be grouped into four main groups:

1) The first and generally the most popular group of methods is based on matching an assemblage of taxa present in a fossil pollen sample with unknown climate, with the same assemblage in a modern pollen sample whose climate is known. This includes the classic modern analogue technique (MAT), but also variants such as response surfaces (Brewer et al., 2007). Advantages include simplicity and an ability to incorporate non-linear responses to climate, while disadvantages include the need for a large calibration dataset of modern pollen samples and poor statistical treatment of uncertainties.

2) The second group of methods builds a regression model for each taxon based on the relationship between modern pollen samples and known modern climate, which is then used to deduct the past climate from the taxa in a fossil pollen sample assemblage. This includes 
the popular Weighted Averaging - Partial Least Squares (WA-PLS) method (Birks et al. 2010). The advantage of this method includes better statistical treatment of uncertainties and elimination of problems such as spatial auto-correlation that are common to MAT. However disadvantages include heavy reliance on capturing the correct climate response within the calibration dataset and poor performance at the edges of the response envelope.

3) Both the previous two groups of methods require an extensive and representative modern pollen surface sample dataset for calibration of the transfer function, and also rely on the relative proportions of the taxa in the pollen assemblage. The third group of methods instead uses modern vegetation distribution rather than modern pollen samples as the basis for calibrating the transfer function, and generally uses presence and absence of taxa rather than its proportional occurrence in the assemblage. This includes classic methods such as mutual climatic range, as well as the more recent probability density function approach (Chevalier et al., 2014). These methods work by establishing the climate envelope for each taxon based on its modern vegetation distribution, and then combining the envelopes of the taxa found in the fossil pollen assemblage to deduce the most likely climate where all the taxa are able to exist together. This group of methods does not require a calibration dataset of modern pollen samples. They are especially good in areas where these datasets are limited such as in Africa (Chevalier et al., 2014), as well as being able to perform in no-analogue situations where taxa are found combined in assemblages that are not found today. The disadvantages of this type of model is that pollen may be found in areas beyond the geographical range of its source vegetation, while the use of geographical range alone to define the optimum climate for a taxa (rather than abundance) leads to large envelopes and consequently large uncertainties in reconstructions.

4) The final fourth group of methods uses a process based vegetation model to determine the climate of a fossil pollen assemblage. Normally vegetation models use climate data as input to 
arrive at a vegetation, but in this 'inverse' method, the vegetation model is used in inverse mode where the vegetation is already known (the fossil pollen assemblage) and the most likely climate to result in that vegetation is the output. This method does not require any modern calibration data (although in reality vegetation models are largely parameterized based on what we know of modern vegetation), and since it is process based, it can provide reconstructions in no-analogue situations such as low $\mathrm{CO}_{2}$ climates (Wu et al., 2007). The importance of pollen-based climate reconstructions are likely to increase in future as more climate models simulations are made in transient mode and at increasing spatial resolutions. At the same time, more fossil and modern calibration pollen data becomes available in public relational databases. Improvements in transfer function performance can also be expected, particularly through the application of Bayesian approaches that include multi-sample and multi-site analysis.

\subsection{Information from microcharcoal}

Vegetation fires produce different sizes of particles of which the smallest, classified as fine particles, are deposited far from the source (Patterson et al., 1987). Aeolian and fluvial processes are the main agent responsible for the transport of microcharcoal from the combustion site to the sedimentation basin where they are preserved. These microcharcoal particles remain in the atmosphere and are transported over long distances (Clark, 1988) by low atmospheric winds $(<10 \mathrm{~km})$ and deposited a few days or weeks after their formation (Clark and Hussey, 1996; Palmer and Northcutt, 1975). In water, after a short period of bedload transport, charred fragments break down into relatively resistant, somewhat rounded pieces, and thereafter remain stable. They exhibit the same behaviour as fragments of highly vesiculated pumice, which initially floats and then sinks as it becomes waterlogged (Nichols 
et al., 2000). Whitlock and Millspaugh (1996) have reported charcoal introduced into deep lake sedimentary record within a few years after a fire event. Suspended fine material (including microcharcoal) fluvially supplied to the ocean can be transported to the deep ocean through canyons (Jouanneau et al., 1998). Microcharcoal sedimentation, which may be comparable to pollen sedimentation behaviour, can lead to deposition within several weeks on the ocean floor as a part of the marine snow (Chmura et al., 1999; Hooghiemstra et al., 1992). It is assumed that microcharcoal mostly reflects regional fire history.

Microcharcoal accumulations (concentrations and influx) are used therefore to reconstruct changes in biomass burning at regional scale. The chronology of the record, through the development of age models, is used to calculate the sediment accumulation rate (sediment accumulation thickness per unit time, $\mathrm{cm} / \mathrm{yr}$ ). Microcharcoal influx (also called microcharcoal accumulation rate) is expressed as number of fragments per unit area per unit time (\#/cm2/yr) or total areas of microcharcoal per unit area per unit time $\left(\mu \mathrm{m}^{2} / \mathrm{cm}^{2} / \mathrm{yr}\right)$. It is calculated by multiplying the concentration of microcharcoal per volume by the sediment accumulation rates, or by multiplying the concentration of microcharcoal per weight by the density of the sediment samples and by the sediment accumulation rates.

Influx accounts for variations in the sedimentation rate over time which can vary widely (Adolf et al., 2018b; Marlon et al., 2016). When the sediments are varved, it is possible to obtain an accurate estimation of the sediment accumulation rate and to calculate microcharcoal influx for each sample (Maher, 1981). In this case, assuming that the full production of microcharcoal is transported to the sediment deposition site, microcharcoal influx may be interpreted directly in terms of charcoal production.

However, varved-sediments are rare and the age-depth model of sedimentary sequence commonly derives from discrete dated levels (radiometric dating, or use of "tie-points" based on events stratigraphy). Several studies then present calculated values of microcharcoal influx 
for each sample of the dated sequence. However, an average sedimentation rate over several meters of core lacks information about the rate in a sample taken from a centimeter interval within the dated sequence (Maher, 1981). Because of this uncertainty in the sedimentation rate, a rigorous solution is not possible for a single sample: interpreting long term trends in microcharcoal influx is preferred rather than interpreting single microcharcoal influx variation. Maher (1981) suggested using in this case an averaged influx between two dates, calculated by the average concentration multiplied by the average sedimentation rate. More recently, the ${ }^{230} \mathrm{Th}$ normalization method provides a means of achieving more accurate interpretations of sedimentary fluxes in marine realm (Francois et al., 2004). In addition, calculation of microcharcoal influxes for some marine sediment sequences obtained by piston coring may be prevented. The piston coring process sometimes elongates parts of the core, and this elongation is not constant over the sequence. It can increase virtually the sedimentation rate and so the derived influx. The coring artefacts should be corrected before influx calculation, if physical parameters of the coring are recorded during the core collection (Toucanne et al., 2009). For some cores collected in the past decades, some missing parameters avoid this correction. The equipment of the upgraded R/V Marion Dufresne for example now prevents or minimizes elastic stretching of the sediment and allows physical parameters to be recorded (http://www.insu.cnrs.fr/en/node/5762).

In a few cases, some "apparent" sediment hiatuses of tens of centimeters in the core are observed. In the absence of changes in lithology, those apparent sediment hiatuses may happen because of the splitting of the sediment due to stretching strength during core collection. The original depths therefore need to be corrected before the calculation of the depth-age model and of the influx (see for example core MD04-2845 in Sánchez Goñi et al., 2017). In addition, the lack of information about the density of the sediment may also prevent 
influx calculation from microcharcoal concentration per weight. However, it is possible to use an estimated marine sediment density (Tenzer and Gladkikh, 2014).

The deep ocean (in the absence of turbidite deposits) receives plant microfossils and terrigenous sediments coming from the adjacent continent and material derived from in situ biological surface productivity. Those materials are part of the hemipelagic sedimentation. Quick events of high sediment accumulation of material produced outside of the adjacent continent or outside of the depositional basin may happen, such as Ice Rafted Debris (IRD) deposits (due to the melting of icebergs during abrupt ice sheet-calving) in the marine realm, or volcanic ash deposits. The sedimentation rate increases sharply and so the calculated microfossil influx. However, this influx increase informs on the modification of the sediment source arearather than an increasing amount of microfossils reaching the depositional basin. For example, core MD04-2845, located on a seamount, receives hemipelagic sediment including allochthonous terrigenous material, i.e. eolian and fluvial particles coming from the adjacent continent, including plant microfossils (Daniau et al., 2009). During the last glacial period, several events of high sedimentation rate are associated with the Heinrich layers, i.e. a huge amount of IRD released during the melting of icebergs in the North Atlantic. To estimate plant microfossil influx, biogenic and glacial terrigenous influx (IRD) should be removed from the total sediment influx. Caution is therefore needed in interpreting influx when the source area of the sediments is modified.

Rare calibration studies, performed in varved sediment lakes and oceanic basin, suggest that microcharcoal accumulation is strongly linked to "burnt area" (Mensing et al., 1999; Tinner et al., 1998) but further investigations are required (Adolf et al., 2018b).

In addition to microcharcoal concentration or influx, the morphology of charcoal including the elongation ratio may provide information about the type of burnt vegetation in palaeoecological and palaeoenvironmental studies (Aleman et al., 2013a; Courtney Mustaphi 
and Pisaric, 2014; Daniau et al., 2013; Daniau et al., 2007). Charcoal fragmentation occurs along axes derived from the anatomical structure of plant species and the elongation degree is preserved even when the particle is broken (Clark, 1984; Umbanhowar and McGrath, 1998). Experimental studies show that the dominance of elongated particles (high elongation ratio) in a sample characterizes herbaceous vegetation burning while a near-squared morphology (low ratio) indicates forest burning (Crawford and Belcher, 2014; Umbanhowar and McGrath, 1998).

\subsection{Information from phytoliths}

Phytolith deposition and accumulation are associated with the decomposition of local vegetation (Piperno, 2006). Phytolith studies can provide valuable complementary information to the analysis of pollen grains that have a larger source area. However, since grasses produce much more phytoliths than any other plant types, the direct environment of the sedimentary archive needs to be carefully described and studied. For example, it has been shown in some African studies that a lake surrounded by a grass-marsh will record a 'super' local signal, i.e. the signal from the marsh overrides the signal from the surrounding landscape (Aleman et al., 2014). In this case, the source area is very local and the main transportation mode is by run-off. Conversely, a lake surrounded by a riparian forest faithfully records the landscape surrounding the lake (Aleman et al., 2014). The source area is wider and the main transportation mode is wind-blown (Aleman et al., 2014; Alexandre et al., 1997; Bremond et al., 2005b). Knowing the taphonomic processes is therefore of particular importance when interpreting a microfossil assemblage and the derived indices (see Strömberg et al., 2018).

\subsubsection{Land cover reconstructions from phytoliths}


The phytolith tree cover index or $\mathrm{D} / \mathrm{P}$ which is the ratio of woody dicotyledons to Poaceae phytoliths is commonly used to characterize the openness of an environment (Alexandre et al., 1997). It has been quantitatively calibrated against the Leaf Area Index (LAI) in two studies from Africa (Aleman et al., 2012; Bremond et al., 2005a). Recently, the D/P index was slightly changed from the original calibration publication to avoid infinite values of ratio. The ratio used is $\mathrm{D} /(\mathrm{D}+\mathrm{P})$, with $\mathrm{D}$ corresponding only to the globular granulate and $\mathrm{P}$ only to the GSSC (Aleman et al., 2014; Bremond et al., 2017). This new index is thus bounded between 0 and 1 making it easier to interpret (Bremond et al., 2017).

This proxy, however, can only be used in tropical environments where D phytoliths are produced. As such, other studies have calibrated LAI against phytoliths derived from leaf epidermal cells for which morphology is light-dependent (Dunn et al., 2015). Indeed, there are large differences between sun leaves and shade leaves: shade leaves have larger and more undulated epidermal cells than sun leaves. Using this proxy, the authors were able to reconstruct LAI for the Cenozoic (49 to $11 \mathrm{Ma}$ ) in middle-latitudes of Patagonia (Dunn et al., 2015).

\subsubsection{Phytolith indices, grassland ecosystems and climate}

Several GSSC indices exist and enable characterization of the grassland or grass-dominated type of ecosystem. First, the Iph or humidity-aridity index compares the number of saddle short cell phytoliths against the number of lobate short cell phytoliths observed in a soil/sediment assemblage [Iph $(\%)=$ saddle vs. cross + dumbbell + saddle]. Calibrated for western Africa, the Iph index accurately characterizes the grass cover, allowing the discrimination of Sahelian grass communities from Sudanian ones (Bremond et al., 2005b) 
and the dominance of short-grass or tall-grass savannas (using a boundary of $\sim 20 \%$ ). The Fs or water stress index is computed as the ratio of bulliform phytoliths over the sum of characteristic phytoliths [fan-shaped index $(\mathrm{Fs})(\%)=$ fan-shaped vs. sum of characteristic phytoliths]. It was calibrated over the same area as the Iph index by using modern soil assemblages and climate data (Bremond et al., 2005a) and was proven successful to record the water stress and transpiration experienced by the grass cover. While the calibration is relevant for this part of Africa, care must be used when applied in other bio-climatic zones.

The Iaq index refers to the percentage of grass short cell morphotypes present in a soil/sediment assemblage that are mostly produced by hydro-/helophytic (=aquatic) grass species (Novello et al., 2012). It was calibrated for Chad (central Africa), where the Iaq index was shown to display high values for samples from the vegetated marshes of the current Lake Chad where aquatic grass communities are largely represented (Novello et al., 2012; Novello et al., 2015; Novello et al., 2016). Additionally, recent studies (Novello et al., 2015; Novello et al., 2016) have demonstrated that an Iaq value of $34.5 \%$ or more is estimated to represent the signal of aquatic grass communities in a fossil assemblage.

Combining indices can improve the interpretation of past grass-dominated communities (Strömberg, 2004). For example, the combination of the Iaq and Iph indices, calculated for each of the fossil assemblages, may allow differentiation of the signal of the dry-loving grass communities (mostly observed in arid domain), from the signal of the humidity-loving grass communities associated with regional high precipitation (mostly observed in wetter domain) or else with local aquatic conditions (Novello et al., 2012).

\subsection{Online data sharing for regional and global environmental data syntheses using plant microfossil data}


Terrestrial plant microfossil data from a sedimentary archive are slow to generate but rich in information on past local to sub-regional changes in vegetation and fire dynamics, paleoclimates and paleoecology. It is therefore important to continue the training of the next generation of scientists on terrestrial plant microfossils. Data needs to be carefully archived for long-term storage. Data from a specific site or a dataset can be archived easily (for instance, the NOAA, http://www.noaa.gov/ and Pangaea, https://www.pangaea.de/, offer this service to the palaeo scientific community).

Over the past 15 years, the increasing amount of plant microfossil data and the establishment of data sharing in the scientific culture (although some barriers still exist, hampering data sharing and good management practice, Neylon, 2017), and the development of large dataset analysis skills has opened the possibility to tackle new questions at regional and global scales. Databases including plant microfossils are useful tools for comparing different records, for reconstructing past regional dynamics of vegetation, fire and climate, and for examining their feedbacks to climate. Those databases are also key for evaluating modeling results of past climate, vegetation and fire. For example, the analysis of the European Pollen Database allowed re-examination of the mean annual temperature trend over the Holocene (Marsicek et al., 2018). Databases will make it possible also to tackle questions arising from global environmental change such as acclimation, adaptation, migration, risk and safe-operating space ecosystems.

Some databases can be focused on one proxy, on one continent or on a specific time period of interest. The structure of the existing palaeo databases is generally similar and includes key metadata as geospatial and dating (chronological) information as well as data in the form of pollen and charcoal counts. The main structure includes sites, samples, pollen or charcoal data, and dating tables. 
The Global Pollen Database (GPD) has now been replaced by the new Neotoma multi-proxy palaeoecological database. The North American Pollen Database is already included in Neotoma. The other regional constituent databases of the GPD, such as the European Pollen Database, the Latin American Pollen Database and the African Pollen Database, are in the process of being absorbed into the new structure as quickly as resources permit it (largely through voluntary efforts). It is hoped that regional pollen databases presently outside of the public domain such as the Chinese and Indo-Pacific Pollen Databases will ultimately be made available through Neotoma over the next few years. It should be noted that all of these databases are relational databases composed of interlinked tables, together with a harmonized and standardized taxonomy, and including additional information on related aspects such as chronologies. In this way, they differ markedly from simple data archives such as NOAA palaeoclimate and Pangaea, which only provide file storage. By creating a global interlinked database, Neotoma is providing the scientific community with a powerful new analysis tool, and one that will allow analysis of not just pollen data but all kinds of palaeocological information.

The Global Charcoal Database (GCD) holds hundreds of fire history records from six continents mostly based on the analyses of macro and micro-charcoal particles in terrestrial and marine sediments. Successive global syntheses based on increasing number of quantitative data demonstrated a strong relationship between fire and climate over the past 21,000 years (Daniau et al., 2012; Marlon et al., 2016; Power et al., 2008). As charcoal values vary by orders of magnitude between and within sites the data have to be standardised to facilitate comparisons between sites and through time. A full description of the procedure and details about the contents of the database can be found in Marlon et al. (2008) and Power et al. (2010b). The current version of the database is now stored under the MySQL environment at gpwg.paleofire.org. The paleofire R package (Blarquez et al., 2014) allows easy access to 
the GCD data and manipulation of its contents to produce biomass burning reconstructions for subsets of records.

The ACER (Abrupt Climate Changes and Environmental Responses) global pollen and charcoal database (Sánchez Goñi et al., 2017) aims to examine changes in vegetation and fire during the last glacial period (73-15 ka), a period of rapid climate changes marked by the socalled Dansgaard-Oeschger (D-O) cycles. The database includes 93 pollen records with a temporal resolution better than 1000 years, 32 of these sites also provide charcoal records. In order to compare patterns of change from different regions, harmonized and consistent chronology based mostly on radiometric dating and few additional tie points based on event stratigraphy below ${ }^{14} \mathrm{C}$ dating limit or below ${ }^{14} \mathrm{C}$ levels has been constructed for ninety six of these records.

The ACER synthesis emphasized the scarcity of palaeoclimatic records from the tropical regions with enough resolution to investigate millennial-scale climate events (Harrison and Goñi, 2010; Sánchez Goñi et al., 2017). The Latin American ACER (LaACER) project was conceived to fill this gap by compiling and synthesizing data from the American tropics and subtropics. Palaeoclimate records of these regions may help understanding globally-important oceanic and atmospheric systems in the climate variability since these regions are influenced by the Pacific and Atlantic oceans, and by large-scale atmospheric features including the Intertropical convergence Zone (ITCZ), El Niño-Southern Oscillation (ENSO), the North American Monsoon (NAM) and the South American Summer Monsoon (SASM) (Garreaud et al., 2009). LaACER sits within the Palaeoclimate commission of INQUA, and was cosponsored by PAGES (Urrego et al., 2014).

\begin{tabular}{|l|l|l|l|l|l|}
\hline Acrony & Full name & Status & Website link & proxy & Key \\
\hline
\end{tabular}




\begin{tabular}{|c|c|c|c|c|c|}
\hline m & & & & & references \\
\hline APD & $\begin{array}{l}\text { African Pollen } \\
\text { Database }\end{array}$ & archive & & pollen & $\begin{array}{l}\text { Vincens et } \\
\text { al. (2007) }\end{array}$ \\
\hline EPD & $\begin{array}{l}\text { European Pollen } \\
\text { Database }\end{array}$ & Active & $\begin{array}{l}\text { http://www.e } \\
\text { uropeanpolle } \\
\text { ndatabase.net } \\
\text { /data/ }\end{array}$ & pollen & $\begin{array}{l}\text { Giesecke et } \\
\text { al. (2014) }\end{array}$ \\
\hline GCD & $\begin{array}{l}\text { Global Charcoal } \\
\text { Database }\end{array}$ & $\begin{array}{l}\text { Active, } \\
\text { MySQL }\end{array}$ & $\begin{array}{l}\text { https://paleof } \\
\text { ire.org/ }\end{array}$ & charcoal & $\begin{array}{l}\text { V1: Power et } \\
\text { al. (2008) } \\
\text { V2: Daniau } \\
\text { et al. (2012) } \\
\text { V3: Marlon } \\
\text { et al. (2016) } \\
\text { V4: in } \\
\text { progress }\end{array}$ \\
\hline $\begin{array}{l}\text { ACER } \\
\text { and } \\
\text { LaACER }\end{array}$ & & $\begin{array}{l}\text { archived in } \\
\text { Microsoft } \\
\text { AccessTM at } \\
\underline{\text { https://doi.or }} \\
\text { g/10.1594/P } \\
\text { ANGAEA.8 } \\
\text { 70867. }\end{array}$ & & $\begin{array}{l}\text { Pollen and } \\
\text { charcoal - } \\
\text { focus on the } \\
\text { last glacial } \\
\text { period }\end{array}$ & $\begin{array}{l}\text { Sánchez } \\
\text { Goñi et al. } \\
\text { (2017) }\end{array}$ \\
\hline
\end{tabular}




\begin{tabular}{|l|l|l|l|l|l|}
\hline Neotoma & Neotoma & Active & http://www.n & Various & (Williams et \\
& Paleoecology & & eotomadb.or & palaeoecolog & al., 2018) \\
& Database & & $\mathrm{g}$ & ical data & \\
& & & & including & \\
& & & & pollen & \\
\hline
\end{tabular}

Table 3: List of databases including pollen and microcharcoal sedimentary records

\section{Glacial-interglacials cycles of the 100 -ky world and the climatic shift of the Mid- Bruhnes event during the Middle Pleistocene}

\subsection{Vegetation}

For the last climatic cycle, vegetation reconstructions and simulations suggest that temperate forests dominated the mid-latitude landscape during the last interglacial while steppe and tundra largely expanded, south of a large area covered by ice-sheets, during the last glacial period (e.g. Harrison et al., 1995; Harrison and Prentice, 2003; Hoogakker et al., 2016). The interglacial-glacial cooling generated a fragmentation of the boreal and temperate forests. Their area of extent during the LGM was greatly reduced in Eurasia while they migrated southward in eastern North America. Temperature variations as well as the low $\mathrm{CO}_{2}$ concentrations, which have a direct physiological effect on plants, strongly influenced the vegetation worldwide during the last glacial period (e.g. Bennett and Willis, 2000; Harrison and Prentice, 2003). For further details, the reader is directed to a set of review papers providing state of the art knowledge on vegetation changes on each continent based on Late Pleistocene pollen records (Bigelow, 2013; de Beaulieu et al., 2013; Hooghiemstra and 
Berrio, 2013; Kershaw and van der Kaars, 2013; Lozhkin and Anderson, 2013; Meadows and Chase, 2013; Thompson, 2013; Urrego et al., 2016). Hereafter, we will focus on vegetation changes during the Middle Pleistocene, from 781 to $126 \mathrm{kyr}$ ago.

Several terrestrial and marine continuous pollen records covering only part of the Middle Pleistocene exist. Here we review the long pollen sequences covering continuously the full Middle Pleistocene. The most well-known terrestrial long pollen sequences were recovered in the sixties and seventies in southern Europe and South America: Tenaghi Philippon and Funza (Fig. 5 and 6). They yield a 1.35 Ma continuous history of the vegetation and climate in the Philippi plain from Greece (Tzedakis et al., 2006; Van Der Wiel and Wijmstra, 1987a, b; Wijmstra, 1969; Wijmstra and Smit, 1976) and a 2.25 Ma history of the tropical Andean vegetation in the Bogotá high plain from Colombia (Hooghiemstra, 1989; Torres et al., 2013), respectively. Over the past two decades, a huge effort was made in the frame of the ICDP (International Continental scientific Drilling Program) to drill ancient lakes and recover long terrestrial sedimentary archives. In particular, the Heqing lake drilling yielded an outstanding pollen sequence recording the vegetation and Asian monsoon variability in southwestern China over the last 2.6 Ma (Xiao et al., 2007; Xiao et al., 2010; Zhisheng et al., 2011). Sedimentary archives going back to 1.8 and 1.2 Ma were also collected from the tropical African lakes Bosumtwi and Malawi and pollen records were generated for the last 540 and 600 kyr, respectively (Ivory et al., 2016; Ivory et al., 2018; Miller and Gosling, 2014). In Brazil, a 50 m deep borehole drilled in 2017 at Lake Colônia will allow the study of the response of the Atlantic rainforest and fire to the South American subtropical monsoon variability during the last 1.6 Myr (Ledru et al., 2015; Ledru, pers. comm.). At higher latitudes, pollen data from the famous Siberian drill sites Lake El'gygytgyn, Lake Baikal and Lake Hovsgol are also available. However, pollen data from Lake El'gygytgyn are so far available for selected periods only, mostly interglacial periods (Melles et al., 2012; Wenwei et 
al., 2018). In the Baikal region, although both sedimentary archives are continuous, pollen records are not because of low pollen concentrations in glacial sediments (Prokopenko et al., 2010; Prokopenko et al., 2009). A global synthesis of the available marine pollen records (Sánchez Goñi et al., 2018) reveals that among the 129 sites listed, 19 cover several climatic cycles, eight go beyond the Mid-Brunhes event with only three sites covering entirely the Middle Pleistocene. These sites are the ODP site 1144 from the South China Sea (Sun et al., 2003), the ODP Site 646 off Greenland (de Vernal and Hillaire-Marcel, 2008) and the IODP site U1385 from the SW Iberian margin although pollen data are mostly available for interglacial periods, so far (Sánchez Goñi et al., 2018). One additional site, the ODP site 1075 from the Congo fan, contains pollen data for the interval 600-1050 kyr (Dupont et al., 2001). The Middle Pleistocene sequences reveal that like the last climatic cycle, the past glacialinterglacial cycles forced repeated large biome shifts.

In southern Europe, the 100-kyr cycles are marked by the alternation of interglacial temperate forest and glacial open vegetation as shown by the Tenaghi Philippon and the IODP site U1385 pollen sequences but also in other southern European pollen sequences covering several climatic cycles such as Ioannina and Kopais in Greece (Okuda et al., 2001; Tzedakis, 1993; Tzedakis et al., 1997; Tzedakis et al., 2006), Praclaux in France (de Beaulieu et al., 2001; Reille et al., 2000), Lake Ohrid in Albania (Sadori et al., 2016), Valle di Castiglione in Italy (Follieri et al., 1988) and cores MD99-2331/MD03-2697/MD01-2447 from the NW Iberian margin and MD95-2042/MD01-2443 from the SW Iberian margin (e.g. Desprat et al., 2017; Sánchez Goñi et al., 2018). During all interglacial Marine Isotopic Stages (MIS), two to three major phases of forest expansion occurred, related with low ice volume (warm MIS substages) and boreal summer insolation peaks. Despite small ice volume fluctuations during the interglacial MIS, the temperate tree variations in the Mediterranean region are of high amplitude due to the strong influence of precession on the Mediterranean vegetation (Sánchez 
Goñi et al., 2018; Tzedakis, 2007). However, the most important forest phase often occurs at the beginning of the MIS during the substage with the largest ice volume minimum, corresponding to the interglacial sensu stricto (e.g. Desprat et al., 2017; Tzedakis, 2005). In addition, emblematic constituents of ancient European forests, the so-called "Tertiary relicts", such as Eucomia, Carya, Pterocarya, Cedrus and Tsuga, became extirpated over Europe during the Middle Pleistocene. Most of them disappeared from the Philippi plain during the MIS 16 glacial period, setting the point from which less diverse interglacial forests, similar to the modern one, established in southern Europe (Tzedakis et al., 2006).

In south America, glacial-interglacial temperature changes forced cyclical altitudinal migration of the montane forest and páramo, the open equatorial alpine vegetation, as shown by the Funza sequence and the 280 kyr-long pollen record Fuquene (Groot et al., 2011; Hooghiemstra and Sarmiento, 2001). However, the composition of interglacial Andean forest changed over the last one million years. Quercus immigrated into the Bogota area at $\sim 430 \mathrm{kyr}$ ago, during MIS 12, becoming a major constituent of the Andean forest since MIS 7, competing at high altitudes with Weinmannia and Podocarpus and replacing Polylepis near the upper forest limit (Torres et al., 2013).

In Africa, marine pollen records such as the IODP site 1075 and the 700 kyr-long records M16415-2 and GIK16867-3 located off tropical Africa, indicate that the extent of the major vegetation formations also varies with the $100 \mathrm{kyr}$ glacial-interglacial cycles although migrations of the southern Saharan desert limit appear to be paced by obliquity. In addition, in the tropics the rain forest fluctuated with summer insolation and precession, likely related with the orbital forcing of the monsoon variability (Dupont, 2011; Dupont and Agwu, 1992; Dupont et al., 2001). At the orbital-scale, tropical lowland ecosystems drastically shifted from woodland to savannah in the western Africa and from tropical forest to desert, steppe and 
grassland vegetation in the eastern Africa in response to strong regional hydroclimatic changes (Ivory et al., 2018; Miller et al., 2016).

While the MBE is clearly recorded by marine and ice archives, this event is not a clear feature of pollen records. The amplitude of forest expansion does not appear higher during the postMBE interglacials in southern Europe pollen sequences (i.e. Lake Ohrid, Sadori et al., 2016; IODP site U1385, Sánchez Goñi et al., 2018; Tenaghi Philippon, Tzedakis et al., 2006) nor in northern high latitudes (ODP 646, de Vernal and Hillaire-Marcel, 2008) and tropical Africa and South America (Dupont, 2011; Funza, Torres et al., 2013) records (Fig. 6). In the Heqing basin, Tsuga percentages, an indicator of winter temperature and annual temperature range, also do not display the MBE, although the XRF data show reduced strength of the summer monsoon rainfall during the interglacial peaks of the last $400 \mathrm{kyr}$ likely related to strong interhemispheric interaction (Zhisheng et al., 2011). Simulations with the LOVECLIM model showed that in comparison with pre-MBE interglacials, the post-MBE interglacials are globally warmer mainly during boreal winter in response to both higher atmospheric greenhouse-gas concentrations and increased insolation during this season, in particular in the southern hemisphere (Yin and Berger, 2010). However, this simulated warming differences exhibit a strong regional and seasonal pattern supporting that some regions such as western Europe or tropical South America, were likely not affected by the MBE or as strongly as the southern high latitudes where the largest difference is displayed.

Long pollen sequences also contribute to show that interglacial periods of the past one million years are diverse in terms of intensity, temporal trend, duration as well as spatial variability (Past Interglacials Working Group of PAGES, 2016; Tzedakis et al., 2017). For instance, records from northern high latitudes clearly display this diversity in warming strength, suggesting that some interglacial periods were particularly warm, such as the "superinterglacial” MIS 11 (Melles et al., 2012). During this stage, the southern Greenland ice-sheet 
collapsed (Reyes et al., 2014) allowing the expansion of the boreal conifer Picea in a region usually devoid of trees (de Vernal and Hillaire-Marcel, 2008). In contrast, in the midlatitudes, the difference in warming intensity between interglacials appears tenuous as shown by weak differences in temperate tree percentages in the European pollen records from the NW Iberian margin and the Massif Central (de Beaulieu et al., 2001; Desprat et al., 2017) Pollen records from the southern Iberian margin show that the magnitude of Mediterranean forest development in the Iberian Peninsula substantially differed from one interglacial to another suggesting that the amount of winter precipitation was quite variable (Desprat et al., 2017; Sánchez Goñi et al., 2018). The interglacial hydroclimate variations observed in SW Iberia do not, however, parallel with the high latitude warming strength. The regional variability of the magnitude of temperature and hydroclimate change on land is a strong feature given by the few available Pleistocene sequences. However, an accurate view and understanding of the regional impact of climate changes during warm periods require suitable sedimentary archives to be recovered and analysed in the future.

Figure 5

Figure 6

\subsection{Fire}

The different syntheses of the Global Charcoal Database (Daniau et al., 2012; Marlon et al., 2016; Power et al., 2008) showed that biomass burning varies closely with climate changes. For example, biomass burning increased globally from the Last Glacial Maximum to the Holocene (Fig 6d). Daniau et al. (2012) demonstrated this global increase in biomass burning 
is controlled by rising mean annual temperature and moisture, with temperature being the primary control.

Few biomass burning records document older glacial/interglacial transition. The synthesis of twenty long records of charcoal, registering not only the Holocene but also the Eemian and part of the last glacial period, suggested that biomass burning is generally high during interglacials and low during glacials (Daniau et al., 2010). Similar results were observed more recently from microcharcoal records in Anatolia (Pickarski et al., 2015) and Greece (Lawson et al., 2013), and from a macroscopic charcoal record covering the last ca. $370 \mathrm{kyr}$ in the Andes (Gosling William et al., 2009; Hanselman et al., 2011). Increases of biomass burning during interglacials in the Andes appeared to be associated with increased fuel load from the Polylepis woodlands expansion.

However, other regions in the tropics and the subtropics illustrate the opposite trend in biomass burning, i.e. high level of biomass burning during glacials or during the LGM (Daniau et al., 2013; Inoue et al., 2018; Nelson et al., 2012). A clear cyclic pattern is observed in southern Africa by a marine long microcharcoal record covering several glacial/interglacial cycles over the last 180,000 - 30,000 years (Fig. 7c). Peaks in biomass burning occur during each precession and local summer insolation maxima (Fig. 7b) (Daniau et al., 2013). Under reduced monsoonal activity, dry and fuel-limited interglacials would have reduced fire activity compared to glacials characterized by enhanced precipitation supporting grass-fueled fires. This hypothesis was confirmed by modeling (Woillez et al., 2014) and by vegetation observation (Urrego et al., 2015). Grass-fueled fires were also suggested to be higher under colder climates in China based on the analysis of the black carbon content, another fire proxy, from loess sequences (Wang et al., 2005).

Two long terrestrial charcoal records older than the MBE exist yet. One is from tropical woodland (lake Malawi, eastern Africa) and covers the last 1.2 million years (Ivory et al., 
2016). The charcoal record was only interpreted for the last 600,000 years and the study suggested that fire activity was a component of the ecosystem since the beginning of MIS 7 and a driver of the decline in species richness at 80,000 years (Ivory et al., 2018). Presence of charcoal is also reported in the lake Bosumtwi sequence covering the last 540,000 years, located in the tropical rainforest region of West Africa (Miller et al., 2016) but no charcoal time series were presented in this paper.

The longest published record of fire covering the last one million years is from Bird and Cali (1998) but is a measure of organic resistant elemental carbon (OREC). Originally, they reported peaks in fire activity at the transitions from interglacial to glacial modes since MIS 13. The only peak during a full interglacial occurred at MIS 1 and was interpreted as of anthropogenic origin because no peak in fire was observed during other past interglacials. They later published a revised chronology of the record (Bird and Cali, 2002) showing that fire also peaked during the interglacial MIS 7, their anthropogenic influence hypothesis from their original paper being then challenged. The microcharcoal analyses (Daniau A-L, work in progress) on the IODP site U1385 from the SW Iberian margin (Sánchez Goñi et al., 2018) covering the last one million years will allow exploration of patterns of fire at orbital-scale in relation to changes in vegetation and hydrology in a region considered highly vulnerable to future fires (Settele et al., 2014).

\section{Millennial-scale changes during the last glacial period}

\subsection{Vegetation}

About 200 pollen records cover the last glacial period worldwide, but only half have sufficient resolution and dating control to show millennial-scale variability (Harrison and Goñi, 2010). 
Here we illustrate patterns of vegetation in response to Dansgaard-Oeschger events (D-O) focusing on Europe, North America, Africa and South America obtained from the synthesis of the ACER International Focus group in 2010 (Fletcher et al., 2010; Hessler et al., 2010b; Jimenez-Moreno et al., 2010; Sanchez Goñi and Harrison, 2010). Those patterns are based on changes in biomes, defined by original authors as pollen percentages of certain taxa. The recent published harmonised chronology (Sánchez Goñi et al., 2017) and the application of biomisation on those records should allow a deeper analysis of the impact of rapid climate change on the land biosphere (Harrison S, pers. comm).

In Europe, high temporal resolution terrestrial records, such as Lago Grande di Monticchio in Italy (Allen et al., 1999) or Tenaghi Philippon in Greece (Müller et al., 2011), and marine pollen records (for instance MD95-2042, Fig 6h, Sánchez Goñi et al., 2000b) reveal changes in vegetation cover and composition on millennial timescales during the last glacial period. Continuous records spanning the entire last glacial are concentrated in the Mediterranean region and southern Europe, while records from central and northern Europe tend to be fragmentary (Feurdean et al., 2014; Fletcher et al., 2010). Greenland Interstadials (GI) were associated with relatively warm and humid conditions over Europe, promoting the establishment of grassland and shrub tundra in northwestern Europe, shrub-and forest-tundra in northeastern Europe, open boreal forest in central western Europe and the Alpine region, and open temperate forest in southern Europe (Duprat-Oualid et al., 2017; Fletcher et al., 2010). Greenland Stadials (GS) or Heinrich Stadials (HS) were marked by cool and dry climatic conditions over Europe and by the expansion of xerophytic and steppe taxa (Fletcher et al., 2010). Marine pollen records from the Atlantic and Mediterranean furthermore play a vital role in demonstrating the effective synchrony of atmospheric and oceanic signals of D-O variability (Naughton et al., 2009; Roucoux et al., 2005; Sánchez Goñi et al., 2002; Sánchez Goñi et al., 2000b), since vegetation changes typically display a one-to-one match with 
millennial-scale changes in marine palaeoclimate tracers such as foraminiferal assemblages, organic biomarkers or ice-rafted detritus (in the Atlantic) (Sánchez Goñi et al., 2018). In addition, high temporal resolution records from the Iberian margin show that vegetation/climate response to HS is even more complex, marked by two or three phases (Fletcher and Sanchez Goñi, 2008; Naughton et al., 2007; Naughton et al., 2009; Naughton et al., 2016). In particular the last HS (HS1) (Oldest Dryas on the continent, Naughton et al., 2007) is marked by three synchronous main phases in regions directly influenced by the North Atlantic: a first phase with extremely cold/relatively wet conditions, a second phase characterized by cool/dry conditions, and a last phase with relatively warmer/increasing moisture availability. Both the Atlantic Meridional Oceanic Circulation slowdown and changes in the strength and position of North Atlantic westerlies could explain the temperature and moisture variability within HS 1 in western Iberia (Naughton et al., 2009; Naughton et al., 2016).

In North America, vegetation responded rapidly also to millennial-scale variability but the absolute phasing of this response to Greenland atmospheric surface temperatures remains uncertain. Altitudinal movements of climate-sensitive plant species occurred in the western part characterised by more mountainous regions while the southeast showed latitudinal shifts in vegetation (Jimenez-Moreno et al., 2010). The YD signature is spatially variable. It is clearly marked by a cold reversal in pollen records from the northwest and northeastern North America(Peteet, 1995; Shuman et al., 2002b; Whitlock and Brunelle, 2007). Toward the continental interior, in the Midwest, pollen records do not display vegetation reversal during the YD but distinct plant associations from earlier and later time periods suggesting warmer than before summers and colder than before winters. This vegetation patterns is likely related to the unique combination of forcings (Shuman et al., 2002a). In contrast, warmer and wetter conditions during the YD and the HS are recorded in Florida at Lake Tulane (Grimm, 2006). 
The YD atypical warming is even detected up to the Virginia Appalachians, at Browns Pond, although at the same latitude, the Chesapeake Bay pollen record indicates cooler and drier conditions close to the coast (Kneller and Peteet, 1999; Willard, 2013).

Tropical Africa and South America present few high resolution records covering the full glacial period. The compilation of Hessler et al. (2010a) based on about 16 pollen records showed that the vegetation signature of HS and GI can be opposite between the northern and southern parts of the region influenced by the ITCZ. The ITCZ influence is particularly well evidenced in northeastern Brazil where rainforest development during the HS 1 is related to its southward shift (Ledru et al., 2006). Furthermore, concomitant lowland vegetation changes between this region and western Patagonia reveal that the ITCZ and the southern westerlies shifted together through an atmospheric teleconnection regulated by the Atlantic meridional oceanic circulation variations (Montade et al., 2015). The recent study of Urrego et al. (2016) identified rapid responses of the tropical vegetation to millennial-scale climate variability in the Andean tropics. They found that Andean forest migrations as far as $16.5^{\circ}$ south of the Equator displayed millennial-scale climate oscillations closely linked to the Greenland ice core (Wolff et al., 2010) and North-Atlantic records (Martrat et al., 2007). The signature of HS and the Younger Dryas were generally recorded as downslope migrations of Andean forest and likely linked to air temperature cooling. The GI-1 signal is overall comparable between northern and southern records and indicates upslope Andean forest migrations and warming in the tropical Andes. Cooling during northern hemisphere stadials and warming during interstadials recorded by Andean vegetation was consistent with millennial-scale fluctuations of $\delta^{18} \mathrm{O}$ in the Sajama ice cap and Uk'37-derived sea surface temperature (SST) changes in the western tropical Atlantic. However, differences in amplitude between SST changes and forest migrations suggested a potential difference between the magnitude of temperature change in the ocean and the atmosphere that could be related to the thermal 
inertia of the oceans. Together these findings suggest that the precipitation signature of millennial-scale events follows the predicted migration of major atmospheric systems and circulation cells, but the temperature signature is driven by northern hemisphere fluctuations.

\subsection{Fire}

Sixty seven sedimentary charcoal records (30 sites with better than millennial resolution) which have records for some part of the last glacial period were compiled to examine changes in global biomass burning to rapid climate changes associated with Dansgaard-Oeschger (DO) cycles (Daniau et al., 2010). This synthesis indicated that biomass burning increased during D-O warming events and decreased during intervals of cooling, including the Heinrich stadials. In addition, this analysis showed that biomass burning responded extremely quickly to rapid climate changes, within a few hundred years. At the global scale, a vegetation productivity forcing was speculated to explain increases (decreases) in fire during D-O warming (cooling) because vegetation itself responds to rapid millennial-scale changes (Daniau et al., 2010). At regional scales, this vegetation productivity hypothesis is clearly supported by a marine record documenting south-western Iberian Peninsula vegetation (Fig. 7h, Sánchez Goñi et al., 2000b) and fire (Fig. 7g, Daniau et al., 2007). Variations in fire dynamics are related to changes in fuel type and quantity due to shifts between semi-desert vegetation during D-O stadials and Heinrich stadials and Mediterranean forest during D-O interstadial (Daniau et al., 2007).

Other proxies like ammonium from Greenland ice cores also exhibit D-O cycles, with increases in fire in North America during GI (Fig 7e, Fischer et al., 2015). A pattern of D-O cycles is also observed in the Australasian region (Mooney et al., 2011). 
The Younger Dryas ( 12.9 - 11.6 thousand years ago) was the last of a series of abrupt deglacial climate events and its end marks the beginning of the Holocene. Charcoal records across North America were synthesized for the YD interval in part to address a hypothesis that a large comet impact caused the climate change and set of continent-wide wildfires. The fire synthesis from Marlon et al. (2009) provided no evidence for this, but did indicate widespread fire activity at both the beginning and end of the YD interval, suggesting that fire increases with large and rapid climate changes and associated ecosystem reorganizations. In the central American lowlands, fire activity increased during Greenland stadials and decreased during interstadials (Correa-Metrio et al., 2012) although the direction of this relationship is heavily dependent on record chronology.

Figure 7

\section{Post-glacial vegetation and fire changes}

\subsection{Europe}

At the beginning of the Holocene, the higher summer insolation, rising greenhouse gas levels and retreating residual LGM ice-sheets caused a general warming of the climate that encouraged the spread of early-successional trees such as birch (Betula) and pine (Pinus) across Europe and the arrival of other arboreal taxa from their glacial refugia. This post glacial development led to a rapid change in the abundance and composition of plant taxa (Birks and Birks, 2008; Marquer et al., 2014). The mid-Holocene represented the warmest period of the Holocene over higher latitudes of the northern hemisphere, and in Europe was characterized by the spread northward of temperate deciduous trees, e.g. hazel (Corylus), elm 
(Ulmus), lime (Tilia), oak (Quercus) and alder (Alnus) (Birks, 1986). Over southern Europe, temperate deciduous vegetation also expanded during the mid-Holocene (Brewer et al., 2017; Collins et al., 2012; Davis et al., 2015; Prentice et al., 1996), indicative of cooler and wetter summers at this time over most (Davis and Brewer, 2009; Davis et al., 2003a; Hessler et al., 2014; Huntley and Prentice, 1988; Mauri et al., 2015; Wu et al., 2007), but not all of the region (Samartin et al., 2017). From the mid-Holocene, the climate cooled over northern Europe and generally warmed over southern Europe, following a decline in summer insolation (Imbrie et al., 1992) and weakening of the Earth's latitudinal temperature and insolation gradient (Davis and Brewer, 2009). In the circum-Mediterranean lands, forest expansion was not limited by distance to glacial refugia and where moisture levels permitted, forests developed rapidly in the early Holocene, or indeed had already developed during the Late Glacial (e.g. Allen et al., 2002; Fletcher and Sanchez Goñi, 2008). In drier settings, including Mediterranean North Africa, steppic, scrub and open woodland landscapes often persisted into the Early Holocene (Campbell et al., 2017), delaying the maximum development of mixed Mediterranean and temperate forest cover until the later Early Holocene and Mid-Holocene. During the Mid-Holocene (typically from ca. $5 \mathrm{ka}$ ), forests declined in the Western Mediterranean associated with a gradual aridification trend (Carrión et al., 2010; Chabaud et al., 2014; Fletcher and Sanchez Goñi, 2008), while in the central Mediterranean compositional changes including increase in Mediterranean elements is recorded (Allen et al., 2002; Desprat et al., 2013).

The development of pollen records at high sampling resolution, with strong dating control and often in a multiproxy investigative framework has also yielded a major contribution to the understanding of Holocene vegetation responses to climate on short timescales. Pollen records have played an important role in evaluating the speed of ecosystem response to global climate change at the onset of the Holocene. They reveal that vegetation responses to major climatic 
perturbation initiated within a few decades, on timescales similar to those observed in fastreacting tracers such as the Greenland ice cores (Birks and Ammann, 2000). High-resolution pollen records also reveal vegetation responses to rapid climate changes during the Holocene. The 8.2 ka abrupt cooling event has been widely detected (see for example Ghilardi and O’Connell, 2013; Pross et al., 2009; Tinner and Lotter, 2001). Numerous pollen records also reveal that the $8.2 \mathrm{ka}$ event is not unique, but rather one of several recurrent Holocene cooling events which impacted on vegetation development. For example, the Western Mediterranean pollen records reveal multiple early Holocene climatic perturbations, as well as pervasive variability associated with the North Atlantic Bond Events (Burjachs et al., 2016; Pèlachs et al., 2011; Pérez-Sanz et al., 2013; Ramos-Román et al., 2018). More widely, especially sensitive dynamics can be observed at ecological margins, and pollen records are valuable for reconstructing climate impacts at mountain timberlines (Feurdean et al., 2016; Haas et al., 1998). At the sub-continental spatial scale, pollen records furthermore support the identification of oscillating behaviour in atmospheric circulation systems, thus contributing to the understanding of past dynamics of important modes of variability such as the North Atlantic Oscillation (Di Rita et al., 2018; Fletcher et al., 2013). Against the wealth of pollen evidence for sensitive and rapid vegetation response to Holocene climate variability can also be set important examples of resilience and inertia (Aranbarri et al., 2014) which can ultimately help to refine the understanding of the vegetation-climate interactions at the regional to global scale.

Pollen-based land cover reconstructions (REVEALS approach) show a decline in forest cover from ca. 6 cal kyr BP in temperate and northern Europe, while arable land indicators (such as cereals) become recurrent through time (e.g. Fyfe et al., 2015; Marquer et al., 2017; Marquer et al., 2014; Roberts et al., 2018) (Fig. 8). This landscape openness at a sub-continental scale is caused by intense Neolithic land clearance for agriculture practices. The impact of land-use 
is gradually increasing from the early farming (ca. 7.4 cal ka BP in Central Germany, Shennan et al., 2013) to the last century. During the second half of the Holocene, human pressure increases and results in a spread of arable land, pastures and intensification of deforestation in most of Europe (e.g. Fyfe et al., 2015; Marquer et al., 2017; Ruddiman et al., 2016; Zanon et al., 2018). Land use is then regarded as the primary driver of this decline in forest cover although the role of climate should not be dismissed (Marquer et al., 2017). Identifying the relative role of climatic and anthropogenic forcing of vegetation changes on different temporal and spatial scales is actually a great challenge based on pollen data (Kuosmanen et al., 2018; Marquer et al., 2018; Marquer et al., 2017; Reitalu et al., 2013). The major anthropogenic impacts occur during the last century, although vegetation still remains climatically sensitive (Marquer et al., 2017). In addition, pollen-based REVEALS modelling (Marquer et al., 2014) indicates an underestimation of grassland cover and later timing of landscape openness during the Bronze Age in temperate and northern Europe compared to the use of untransformed pollen data (pollen proportion). Deforestation was therefore more important and started earlier than previously thought. The use of the REVEALS model also provides a deeper understanding of the vegetation rate of changes and the changes in vegetation composition and diversity over time and space.

Figure 8

Over the past 30 years, charcoal-based palaeofire studies have largely developed in Europe because of raising awareness about the importance of fire as both a tool for human-driven landscape transformation and a major ecological factor closely linked to climate and vegetation. This research provided crucial methodological advances like the calibration of the sedimentary charcoal records (Adolf et al., 2018a; Tinner et al., 1998; Tinner et al., 2006), but 
above all a more comprehensive understanding of human-driven fires imprints on forested ecosystems (Tinner et al., 2005), of the mechanisms causing the decline of certain key species (Morales-Molino et al., 2017b; Tinner et al., 1999), and of the connections between climate variability and fire regimes in previously assumed low flammability temperate areas (Clark et al., 1989).

Charcoal-based studies have made a major contribution to the assessment of the chronology and relevance of fire use as a landscape management tool. The first evidence of forest clearance by fire is usually related to the timing of agriculture arrival to the different European regions: e.g. ca. 8 cal kyr BP at the Mesolithic-Neolithic transition in Italy (Vannière et al., 2008), 6.5 cal kyr BP in southwestern France (Rius et al., 2009), 5.7 cal kyr BP in southern Germany (Clark et al., 1989) and ca. 4 cal kyr BP in southern Sweden (Olsson et al., 2010). Significant vegetation changes such as the decline of several keystone tree species like holm oak (Quercus ilex) (Colombaroli et al 2009) and silver fir (Abies alba) in the southern Alps and Tuscany were attributed to the early human use of fire (Colombaroli et al., 2007; Henne et al., 2013; Tinner et al., 1999). Climate remains however the main driver of fire regimes at regional to continental scales until the last millennia (Marlon et al., 2013). For instance, increased fire activity between 11.7 and 6 cal kyr BP was related to stronger boreal summer insolation and/or summer drought (Power et al., 2008) while the decreasing fire activity/frequency recorded since the mid-Holocene is attributed to decreasing seasonality and/or wetter summers (Rius et al., 2011; Vannière et al., 2011). The role of fire, of either anthropogenic or natural origin, in the expansion of some emblematic tree species such as Fagus sylvatica (e.g. Giesecke et al., 2007; Tinner and Lotter, 2006; Valsecchi et al., 2008), on forest composition (Carrión, 2002; Carrión et al., 2003; Gil-Romera et al., 2010), and on the historical vegetation dynamics of currently protected areas (Morales-Molino et al., 2017a; Morales-Molino et al., 2017b) remains matter of debate. 
The palaeofire research has made available a large dataset of individual charcoal and fire frequency records that has enabled a more comprehensive assessment of fire-vegetationclimate-human activities linkages at the continental scale. Recently, a synthesis of around 20 high-resolution charcoal records from Portugal to Romania (Vannière et al., 2016) highlighted that European fire regimes strongly depend on elevation, which underlines the crucial role of vegetation productivity (biomass availability) of temperate and Mediterranean biomes on fire activity at millennial timescales. This work also showed that fire frequency peaked at ca. 7-6 cal kyr BP at the European scale, and remained stable at high level from 4 kyr BP onwards, while burned biomass followed an inverse pattern. The decrease in southern European biomass burning since $7 \mathrm{ka}$ is in line with both orbitally-induced climate cooling and reduction in biomass availability because of land use.

\subsection{North America}

Due to a long history in palynological research in North America, more than 1300 pollen sequences are included in the Neotoma paleoecology database (Williams et al., 2018) covering entirely or part of the last $20 \mathrm{kyr}$, although most of them only contain the Holocene period. Several state of the art papers aim at retracing the North American postglacial vegetation history, such as Gavin and $\mathrm{Hu}$ (2013), Wigand (2013), Whitlock and Brunelle (2007) and Whitlock (1992) for the western part of the sub-continent, Williams and Shuman (2013), Willard (2013), Grimm and Jacobson Jr (2004), Webb et al. (2003), Davis (2015), Davis (1984), Naughton et al. (2015) and Blarquez and Aleman (2016) for the eastern part and Bigelow (2013) for regions above $60^{\circ} \mathrm{N}$. In North America, the deglacial warming (19-11 ka) along with the retreat North American ice-sheets resulted in large range shifts of terrestrial ecosystems. Pollen records reveal a northward and east-west expansion of arboreal taxa in NE 
North America. For instance, northern pines and spruce began their northward migration while mesic and cool-temperate deciduous tree taxa expanded in the southeastern United States after 17 cal ka BP (Willard, 2013). These cold-tolerant conifers expanded with Betula and Alnus in regions formerly occupied by the Laurentide ice-sheet in the NE North America while Pinus, Artemisia and Ambrosia migrated eastward. In the northwestern, high-elevation mesophytic forest taxa expanded to the west of the Cascade Range and Sub-Alpine parkland to the east when warmth and humidity increased and the Cordilleran ice-sheet retreated (at $\sim 16$ cal ka BP), while temperate arboreal taxa only appeared at $\sim 14.5$ cal ka BP associated with Sub-Alpine species (Whitlock and Brunelle, 2007). This plant association no longer exists today in North America. No-analog pollen assemblages characterized by high abundances of the conifers Picea and Larix, the hardwoods Ulmus, Ostrya/ Carpinus, Fraxinus and Quercus, and sedges are widely recorded in the Midwest during the late glacial (17-12 ka BP). This unusual taxa combination is known as mixed parkland or spruce parkland resulting from the individualistic plant response to the no-analog climate conditions characterizing the last deglaciation and helped, at least in some areas, by megafaunal population decline (Jackson and Overpeck, 2000; Williams and Shuman, 2013; Williams et al., 2001).

In eastern North America, the pollen records reveal vegetation shifts in response to the Younger Dryas-Holocene transition warming. Quercus became the dominant forest element in the oak-pine association developing in the southeast due to warmer but persistent dry conditions while in the northeast, white pine, oak and hemlock expanded in areas formerly occupied by cold-tolerant taxa in response to increased warmth and moisture availability (e.g. Naughton et al., 2015; Willard, 2013). In the northeast, temperature and humidity continues to increase in the northern areas to reach a maximum during the Mid-Holocene as suggested by the expansion of pine in New England and oak with some mesic tree taxa toward the south 
during the Early Holocene followed by hemlock (Tsuga) and beech (Fagus) during the MidHolocene (Naughton et al., 2015; Williams and Shuman, 2013). In the southeast, the increase in humidity only occurred in the Mid-Holocene as indicated by the widespread oak-dominated forest decline and pine expansion. Pollen based reconstructions support stronger than present annual precipitation at $6 \mathrm{ka}$ for most of the eastern North America (Bartlein et al., 2011). The Mid-Holocene wet conditions were interrupted a few millennia later, which resulted in the replacement of pine by oak in the south and likely the well-known hemlock sudden decline widely recorded at $5.5 \mathrm{ka}$ in the northeastern North America, although a pest outbreak cannot be discarded (Williams and Shuman, 2013 and references therein). Eastern North American pollen records indicate that dry conditions persisted into the Late Holocene. The Late Holocene increased humidity suggested by vegetation changes in Northeast North America (e.g. Naughton et al., 2015) is supported by tree ring, varve thickness and lake level data (Marlon et al., 2017). A cooling trend in this region over the last 2.5 millennia is also shown by pollen-based summer and annual temperature reconstructions (Marlon et al., 2017 and reference therein). Noticeable human impact on vegetation began with the European colonization 500 years ago, through land clearance practices as shown the large reduction in tree cover and expansion of Ambrosia recorded in eastern North America. In the western North America, the Holocene vegetation changes present a complex pattern due to the heterogeneity of landscape and climatic influences. A main feature revealed by pollen records is that Early Holocene contrasting hydrological changes between the northern and southern regions. Drier (and warmer) than present summers are recorded in the Pacific Northwest to southeastern Alaska and over much of the Northern Rocky Mountains and wetter than present conditions in the American Southwest and the summer-wet regions of the Rocky Mountains in response to stronger summer monsoons (Whitlock and Brunelle, 2007). In the Great Basin, drought-tolerant shrub communities established in the Early Holocene 
associated to drier conditions than today (Jimenez-Moreno et al., 2010; Wigand, 2013).

Pollen-based quantitative reconstructions show lower temperatures at $6 \mathrm{ka}$ than at present and the anomaly also appears stronger in the southwest likely related to the cloud cover generated by the monsoonal circulation (Bartlein et al., 2011). From the middle to late Holocene, western North American pollen records indicate cooler conditions along with increased humidity in the north and dryness in the south likely related to a weakening of the summer monsoon (Whitlock and Brunelle, 2007).

The North American vegetation also responded to higher frequency climatic changes during the Holocene. For instance, the $8.2 \mathrm{ka}$ abrupt cooling event is clearly detected in NE pollen North America (Shuman et al., 2002a). Pollen based temperatures reconstructions show warmer conditions during the Medieval Climate Anomaly than during the Little Ice Age across North America (Viau et al., 2012). Even though differences are subtle, both events are also detected in other proxy-derived reconstructions (Marlon et al., 2017).

Reconstructions of biomass burning from charcoal-based syntheses in four broad regions of North America are generally marked by a gradual and persistent increase in biomass burning during the Holocene except for the northeastern boreal forest (Blarquez et al., 2015). There were large deviations from this general trend in the early Holocene, however, with millennialscale intervals of high fire activity that often started and ended very abruptly (Marlon et al., 2013). For example, in the northwestern boreal forests, there was relatively high fire activity from 12-10 ka, and in the northeast, there was widespread, intensive fire activity from about 10-8 $\mathrm{ka}$ as compared with later intervals. In contrast, fire activity was very low in the west at the same time as compared with late-Holocene fire activity. All regions showed gradual increases during the middle Holocene up to $2 \mathrm{ka}$. Only the continental interior grasslands and woodlands show maximum Holocene burning at 4 ka and subsequently declined. Anthropogenic effects on fire are obvious in the biomass burning records during the past 
century, but the 4-ka peak in burning in the central region likely reflects anthropogenic activity as well.

\subsection{South America}

Evidence of Holocene environmental change from tropical South America showed that the continent was impacted by significant changes in precipitation and intensified human occupation (Prado et al., 2013; Smith and Mayle, 2018; Urrego et al., 2009). A mid-Holocene drought (MHD) is recorded in the Andes, the savannas and Amazonia (Baker et al., 2001; Berrío et al., 2002; Bush et al., 2007; Mayle et al., 2000; Paduano et al., 2003; Rowe et al., 2002; Urrego et al., 2013b) and had a significant impact in the climate and fire regimes of the region. Multiple records indicate lowering of lake levels and reductions in sediment accumulation or sedimentary hiatuses (Bush et al., 2007). However, mesic forest prevailed around sites located in the core of Amazonia and the eastern flank of the Andes (e.g. Bush et al., 2007; Urrego et al., 2010; Urrego et al., 2013a) while savanna vegetation and dry forest expanded in seasonal parts of South America or nearby ecotones (e.g. Berrio et al., 2002; Berrío et al., 2002; Mayle et al., 2000). The MHD is also reported in subtropical South America by palaeodata syntheses predominantly based on pollen records (Prado et al., 2013; Smith and Mayle, 2018). In particular, the replacement of wet forests by shrubs and grasslands are frequently observed in southeastern Brazil during the mid-Holocene (e.g. Behling and Safford, 2010). Only in Northeast Brazil an opposite trend is evidenced, with more humid conditions during the mid-Holocene than during the late Holocene (Smith and Mayle, 2018). Precipitation generally increased during the late Holocene and multiple studies have revealed the interplay between changing climate conditions and human occupation. 
Southward, in temperate regions, records of past vegetation mainly from western Patagonia generally begin after the retreat of the Patagonian Ice Sheet fully extended over the lands during the Last Glacial Maximum (Abarzúa et al., 2004; Bennett et al., 2000; Fontana and Bennett, 2012; Haberle and Bennett, 2004; Heusser, 1995; Markgraf and Huber, 2010; Moreno et al., 1999; Villa-Martínez and Moreno, 2007). At these southern latitudes, vegetation changes followed the same climate trends evidenced by Antarctic ice core records. In particular, the development of Nothofagus forest during the warming of the last deglaciation is interrupted by a cold and wet event contemporaneous with the Atlantic Cold Reversal before to reach Holocene climate conditions (Montade, 2011; Moreno and Videla, 2016). Starting from ca. $11.5 \mathrm{ka}$, the early Holocene is marked by a development of thermophilous tree taxa characterizing a warm and dry phase in northwest Patagonia (Montade et al., 2012; Moreno, 2004). A subsequent expansion of the cold-resistant conifers from $7.5 \mathrm{ka}$ indicate more variable climate conditions superimposed on a cooling trend associated with an increase in precipitation during the mid-Holocene that has persisted until the present (Henríquez et al., 2015). Further south, in southwest Patagonia $\left(>50^{\circ} \mathrm{S}\right)$, the foreststeppe ecotone shifts in lowlands show also a precipitation decrease during the early Holocene followed by a precipitation increase (Fletcher and Moreno, 2011; Moreno et al., 2010). This pattern suggests a co-variability of moisture changes through western Patagonia related to reduced intensity of the southern westerlies during the early Holocene and a sustained increase afterward. However several palaeoenvironmental records from southwestern Patagonia indicate a different pattern characterized by wetter/windier conditions at the beginning of the Holocene followed by intermediate conditions to reduced precipitation from the mid- to late Holocene (Kilian and Lamy, 2012; Lamy et al., 2010). Resolving these inconsistencies in southwest Patagonia still needs more high-resolution records of past vegetation and climate dynamics. 
Synthesis of fire records in South America since the LGM (Power et al., 2010a) shows that fire regimes increased during the late glacial and towards the Holocene. Such an increase in continental-scale fire activity was linked to precipitation seasonality and suggests that fires were mostly likely natural (Power et al., 2010a). However, precipitation seasonality explains only part of the observed variability highlighting the importance of taking fuel availability into account.

The MHD also had a significant impact in fire regimes in tropical South America. Urrego et al. (2013a) compiled fire records from forest, savanna and ecotone sites in western Amazonia. This regional synthesis showed increased fire activity in forest sites at around 9, 6 and $3 \mathrm{ka}$ (Urrego et al., 2013a). The 6-ka fire peak seems the most consistent amongst sites and largely coincides with the MHD. Regional drought during mid-Holocene resulted in increased fire activity in sites where fuel was available. Increased fire activity was also observed in savanna sites during the late Holocene and was probably associated with human occupation (Maezumi et al., 2018; Urrego et al., 2013a; Watling et al., 2017). Finally, multiple fire records in lowland Amazonia consistently show a signal of fire suppression around 1500 AD when precolumbian populations decreased due to the arrival of European colonizers (Burbridge et al., 2004; Bush et al., 2000; Bush et al., 2007; Mourguiart and Ledru, 2003; Urrego et al., 2013a).

\subsection{Central and West Africa}

The distribution of current forests and savannas in West and Central Africa is thought to be the legacy of the long-term history of climate and human impacts. Indeed, palaeoenvironmental reconstructions suggest that West and Central African forests have experienced a succession of contraction and extension (Maley, 1991; Vincens et al., 1999) in response to dry and humid periods since the Last Glacial Maximum (LGM, 21 cal ka BP). 
The LGM was a period of very low precipitation and temperature (Maley, 1991; Shanahan et al., 2016), and some studies suggest that during this period tropical forests were reduced to only few refugia in Central Africa (Maley, 1991; 1996). After the Younger Dryas (from 12.9 to $\sim 11.7 \mathrm{ka} \mathrm{BP}$ ), which was a short but intense dry period (Shanahan et al., 2016), rainfall started to increase at the beginning of the Holocene. During this period, also known as the African Humid Period (deMenocal et al., 2000; Shanahan et al., 2015), rainfall was apparently higher than present-day. The tropical forest was more widespread across West and Central Africa than it currently is. Pollen data suggest that tropical forest was present in the Adamawa Plateau of Cameroon (Lézine et al., 2013; Vincens et al., 2010) and the Niari Valley of the Republic of Congo (Vincens et al., 1994; Vincens et al., 1998). The African Humid Period ended abruptly 4 ka BP, but sequentially in latitude (Shanahan et al., 2015), with a period of reduced precipitation and major droughts that lasted until $1.2 \mathrm{ka} \mathrm{BP}$ (Vincens et al., 1999). This period, called the 'third millennium rainforest crisis', is divided into two major phases (Maley, 2002; Maley et al., 2018; Vincens et al., 1999). The first phase ( 4 ka BP) is associated with an abrupt decrease in rainfall (Maley et al., 2018), that impacted areas in periphery of the Congo Basin and was responsible for the opening of coastal savannas in Central Africa (Elenga et al., 1994; Ngomanda et al., 2005) and of the Dahomey Gap in West Africa (Salzmann and Hoelzmann, 2005). During the same period, savanna vegetation was also heavily modified, with gradual (during the AHP termination) and abrupt (3 ka BP crisis) floristic shifts from Guinean to Sudan-Guinean savanna (Salzmann et al., 2002).

The second phase was short and abrupt, between 2.5 and $2 \mathrm{ka} \mathrm{BP}$, and showed strong climate seasonality as suggested by sea surface temperature reconstructions and geological limestone zones (Maley et al., 2018). Vegetation reconstructions from pollen data showed increasing abundance of pioneer and secondary forest trees, and grasses (Vincens et al., 1999) suggesting that during this period, forests were highly disturbed. Some authors suggested the opening of 
a north-south savanna corridor in the Sangha River Interval (Maley and Willis, 2010) which would have permitted the migration of Bantu-speaking people, but the existence of this corridor is not supported by recent phytolith records in the region (Bremond et al., 2017). Interestingly, the relative role of climate and people in the third millennium crisis has been debated in the literature. Some authors tend to affirm that the Bantu migrations actively participated in the large scale forest disturbance (Bayon et al., 2012; Garcin et al., 2018) while others favor the climate hypothesis (Giresse et al., 2018; Lézine et al., 2013; Maley et al., 2012; Neumann et al., 2012b). This debate is not yet resolved, but it seems that the migration of Bantu people from the border of Cameroon and Nigeria, where they originated, was concomitant with this abrupt climate change (Maley et al., 2018). Moreover, Bantu people were agriculturalists and metallurgists (Bostoen et al., 2015), able to use slash-and-burn and needing large quantities of wood for metallurgy. They were farming pearl millet (Neumann et al., 2012a) and cattle (Grollemund et al., 2015) within the present-day tropical rainforest of western and central Africa. Even if they were not responsible for this large scale event, they may have caused more localized perturbations in the forest through canopy opening and wood collection (Neumann et al., 2012a; van Gemerden et al., 2003). Additionally, with or without the presence of people, even in the deepest part of the forest, charcoal were found in lakes, wetlands and soils, suggesting extended forest burning (Biwolé et al., 2015; Hubau et al., 2015; Morin-Rivat et al., 2016; Tovar et al., 2014). An increase in the occurrence of charcoal is registered when seasonality increased drastically $2.5 \mathrm{ka} \mathrm{BP}$ (Hubau et al., 2015), with a possible role of people in maintaining newly formed savannas in peripheral areas of the Congo forest (Neumann et al., 2012a). After $1.2 \mathrm{ka} \mathrm{BP,} \mathrm{rainfall} \mathrm{started} \mathrm{to} \mathrm{increase} \mathrm{again,} \mathrm{and}$ forest expanded. This trend of forest transgression is still observed today in some areas (Aleman et al., 2018b; Guillet et al., 2001; Youta Happi, 1998). 


\section{Conclusion and perspectives}

Terrestrial plant-derived microfossils -- pollen, microcharcoal and phytoliths -- have been analysed in both terrestrial and marine sedimentary archives for several decades and contributed to the current knowledge of past changes in vegetation and fire dynamics, Quaternary palaeoclimates and palaeoecology. While the study of pollen is considered to be a "classic" tool in this respect, interest in microcharcoal and phytolith represents a more recent area of growth.

Several different techniques are employed to extract microfossils because of the diversity of Quaternary sedimentary contexts, but the main objective is to concentrate microfossils for microscopic observations. Identification and counting of pollen, microcharcoal and phytoliths require specialist expertise. Terrestrial plant microfossil data from sedimentary archives are time-consuming to generate but are rich in information on past local to sub-regional paleoenvironments. It is important therefore to continue improving the identification and interpretation of these microfossils and to keep training the next generation of scientists. The datasets generated also need to be carefully archived and should benefit from long term storage. Over the past 15 years, the growing wealth of plant microfossil data, the establishment of data sharing protocols in the scientific community and the development of large (continental to global) datasets, and the development of new analytical approaches have provided the opportunity to tackle new scientific questions. Key topics at regional and global scales include the response of vegetation and fire to climate change, as well as feedback mechanisms related to both vegetation, such as the vegetation-(snow)-albedo feedback, and fire, such as fire feedback on the carbon cycle and on albedo. Those databases are also key for developing data-model comparison exercises and evaluating modeling results of past climate, 
vegetation and fire. Finally, they are also essential for applying lessons from the past to respond to current biodiversity, conservation and management issues.

This review highlights strong regional variability in the response of past vegetation and fire to Pleistocene climate changes. The different studies synthesized here nevertheless suggest similar patterns: vegetation and fire respond to orbital, millennial and sub-millennial climate changes; and their response may be rapid, within a few hundred years. This review also highlights that climate is the major driver of vegetation and fire regimes since at least the Middle Pleistocene. Human activities impacted on vegetation and fire at local scale mainly since the mid-Holocene and most significantly during recent millennia.

Although terrestrial plant microfossils are well-established tools in Quaternary science, the full extent of the information they contain remains to be exploited. Further calibration studies are needed, e.g. coupling microfossil accumulation in sediments with remotely sensed vegetation and fire. In addition, it is important to keep improving the taxonomic resolution of these plant microfossils. For instance, morphometric analyses of pollen grains coupled with statistical classification methods can in some cases provide greater taxonomic detail within visually similar groups, e.g. Pinus (Desprat et al., 2015; Lindbladh et al., 2002).

Morphological analyses of microcharcoal may bring also important new information for the determination of burnt vegetation type although is not yet a widely used technique (Hawthorne et al., 2018). Recent studies employing techniques from organic geochemistry also highlight how the chemical composition of the preserved pollen wall may yield valuable insights into taxonomy and/or environmental conditions during pollen formation such as past solar radiation (e.g. Bell et al., 2017; Julier et al., 2016; Willis et al., 2011). In sum, the prospects are great for exciting new insights from the study of terrestrial plant microfossils to the understanding of Quaternary environmental and climatic change. 


\section{Acknowledgements}

We thank PAGES and INQUA for supporting the Global Paleofire Working Group (GPWG), the projects on "Abrupt Climate Changes and Environmental Responses" (International Focus Group ACER) and "Latin American Abrupt Climate Changes and Environmental Responses" (LaACER). Financial support was provided by the INSU-IMAGO projects WarmClim,

PuLSE,MIcMAC and CAMPFIRE. Basil Davis was supported by "SNF HORNET Project Grant No. 200021_169598" and Filipa Naughton by ClimHol (PTDC/AACCLI/100157/2008) and Ultimatum (IF/01489/2015) research grants.

\section{Figure captions}

Figure 1: Reconstructing vegetation and fire using plant microfossils (pollen, phytoliths and microcharcoal) (modified from Patterson et al. (1987)).

Figure 2 : Examples of classical fossil pollen grains and spores presented by grain arrangement and pollen apertural type. (a. Pinus; (b) Ericaceae, (c) Cereal type; (d) Poaceae; (e) Carpinus betulus; (f) Betula; (g) Amaranthaceae; (h) Cyperaceae; (i) Aspodelus; (j) Scabiosa; (k) Acer; (1) Quercus deciduous type; (m) Erodium; (n) Olea; (o) Brassicaceae; (p) Aster type; (q) Centaurea scabiosa type; (r) Fagus; (s) Cichorioideae; (t) Ephedra distachya type; (u) Ephedra fragilis type; Spores: (v) Isoetes, (w) Polypodium vulgare type.

Figure 3: Examples of microcharcoal preserved in marine deep-sea core sediments. (a) core MD95-2042 (Daniau et al., 2007); (b) IOPD Site U1385 (Daniau, work in progress); (c) core MD04-2845 (Daniau et al., 2009); (d) core MD96-2098 (Daniau et al., 2013). 
Figure 4: Examples of classical phytoliths grouped into five large categories. (a-i) Grass silica short cells; (i) Bulliform cells; (j-1) Woody dicotyledon; (m-o) Family-specific families morphotypes; (p) Non-diagnostic morphotypes.

Figure 5: Location of the terrestrial and marine pollen and microcharcoal records presented in Fig. 6 and 7. 1- Funza (Torres et al., 2013), 2-Heqing lake (Zhisheng et al., 2011), 3-MD962098 (Daniau et al., 2013), 4- Tenaghi Philippon (Tzedakis et al., 2006), 5-MD95-2042 (Chabaud et al., 2014; Daniau et al., 2007; Sánchez Goñi et al., 2000a; Sánchez Goñi et al., 2008). The background map represents the present-day potential vegetation after (Levavasseur et al., 2012).

Figure 6: Response of vegetation to orbital variability. (a) summer insolation at $65^{\circ} \mathrm{N}$ from Laskar et al. (2004), (b) atmospheric $\mathrm{CO}_{2}$ EPICA Dome C (Bereiter et al., 2015; Monnin et al., 2001; Petit et al., 1999; Siegenthaler et al., 2005), (c) Antarctic air temperature from EPICA-Dome C (Jouzel et al., 2007), (d) LR04 benthic $\delta^{18} \mathrm{O}$ (Lisiecki and Raymo, 2005), (e) arboreal pollen percentages data from Tenaghi Philippon record (Tzedakis et al., 2006), (f) arboreal pollen from Funza sequence (Torres et al., 2013), (g) Tsuga pollen percentages from Heqing lake record (Zhisheng et al., 2011). The grey dashed bar indicates the position of the Mid-Brunhes Event (MBE).

Figure 7: Response of fire and vegetation to orbital and millennial variability. (a) Antarctic air temperature (Jouzel et al., 2007), (b) summer insolation at $25^{\circ} \mathrm{S}$ (Berger, 1978), (c) biomass burning from southern Africa (microcharcoal record from core MD96-2098) (Daniau et al., 2013), (d) biomass burning (z-score of transformed charcoal, about 700 sites) (Daniau et al., 2012), (e) fire peak frequency from Greenland ice core (Fischer et al., 2015), (f) Greenland air temperature from NGRIP ice record (Landais et al., 2004; data compiled in Sánchez Goñi et 
al., 2008), (g) biomass burning from southwestern Iberia (microcharcoal MD95-2042 record)

(Daniau et al., 2007), (h) Mediterranean forest (pollen percentages from core MD95-2042)

from southwestern Iberia (Chabaud et al., 2014; Sánchez Goñi et al., 2000a; Sánchez Goñi et al., 2008).

Figure 8: Example of pollen-based modelling land cover reconstruction for Central Europe (Marquer et al., 2014).

\section{References}

Abarzúa, A.M., Villagrán, C., Moreno, P.I., 2004. Deglacial and postglacial climate history in east-central Isla Grande de Chiloé, southern Chile (43ㅇ). Quaternary Research 62, 49-59. Abramoff, M.D., Magalhães, P.J., Ram, S.J., 2004. Image processing with ImageJ. Biophotonics International 11, 36-42.

Adolf, C., Doyon, F., Klimmek, F., Tinner, W., 2018a. Validating a continental European charcoal calibration dataset. The Holocene, 0959683618782607.

Adolf, C., Wunderle, S., Colombaroli, D., Weber, H., Gobet, E., Heiri, O., van Leeuwen, J.F.N., Bigler, C., Connor, S.E., Gałka, M., La Mantia, T., Makhortykh, S., SvitavskáSvobodová, H., Vannière, B., Tinner, W., 2018b. The sedimentary and remote-sensing reflection of biomass burning in Europe. Global Ecology and Biogeography 27, 199-212. Albert, R.M., Bamford, M.K., Cabanes, D., 2006. Taphonomy of phytoliths and macroplants in different soils from Olduvai Gorge (Tanzania) and the application to Plio-Pleistocene palaeoanthropological samples. Quaternary International 148, 78-94.

Aleman, J., Hennebelle, A., Vannière, B., Blarquez, O., Group, t.G.P.W., 2018a. Sparking New Opportunities for Charcoal-Based Fire History Reconstructions. Fire 1, 7.

Aleman, J., Leys, B., Apema, R., Bentaleb, I., Dubois, M.A., Lamba, B., Lebamba, J., Martin, C., Ngomanda, A., Truc, L., Yangakola, J.-M., Favier, C., Bremond, L., 2012. Reconstructing savanna tree cover from pollen, phytoliths and stable carbon isotopes. Journal of Vegetation Science 23, 187-197.

Aleman, J.C., Blarquez, O., Bentaleb, I., Bonté P., B.B., Carcaillet C., Gond V., GourletFleury S., Kpolita A., Lefèvre I., Oslisly Richard, Power M.J., Yongo O., Bremond L., Favier C., 2013a. Tracking land-cover changes with sedimentary charcoal in the Afrotropics. The Holocene 23, 1853-1862.

Aleman, J.C., Canal-Subitani, S., Favier, C., Bremond, L., 2014. Influence of the local environment on lacustrine sedimentary phytolith records. Palaeogeography, Palaeoclimatology, Palaeoecology 414, 273-283.

Aleman, J.C., Jarzyna, M.A., Staver, A.C., 2018b. Forest extent and deforestation in tropical Africa since 1900. Nature Ecology \& Evolution 2, 26-33. 
Aleman, J.C., Saint-Jean, A., Leys, B., Carcaillet, C., Favier, C., Bremond, L., 2013b. Estimating phytolith influx in lake sediments. Quaternary Research 80, 341-347.

Alexandre, A., Meunier, J.D., Lézine, A.M., Vincens, A., Schwartz, D., 1997. Phytoliths: indicators of grassland dynamics during the late Holocene in intertropical Africa.

Palaeogeography, Palaeoclimatology, Palaeoecology 136, 213-229.

Allen, J.R.M., Brandt, U., Brauer, A., Hubberten, H.-W., Huntley, B., Keller, J., Kraml, M., Mackensen, A., Mingram, J., Negendank, J.F.W., Nowaczyk, N.R., Oberhänsli, H., Watts, W.A., Wulf, S., Zolitschka, B., 1999. Rapid environmental changes in southern Europe during the last glacial period. Nature 400, 740-743.

Allen, J.R.M., Hickler, T., Singarayer, J.S., Sykes, M.T., Valdes, P.J., Huntley, B., 2010. Last glacial vegetation of northern Eurasia. Quaternary Science Reviews 29, 2604-2618.

Allen, J.R.M., Watts, W.A., Huntley, B., 2000. Weichselian palynostratigraphy, palaeovegetation and palaeoenvironment; the record from Lago Grande di Monticchio, southern Italy. Quaternary International 73-74, 91-110.

Allen, J.R.M., Watts, W.A., McGee, E., Huntley, B., 2002. Holocene environmental variability - the record from Lago Grande di Monticchio, Italy. Quaternary International 88, 69-80.

Andersen, S.T., 1960. Silicone oil as a mounting medium for pollen grains. Danmarks Geologiske Undersøgelse Series IV 4, 1-24.

Aranbarri, J., González-Sampériz, P., Valero-Garcés, B., Moreno, A., Gil-Romera, G., Sevilla-Callejo, M., García-Prieto, E., Di Rita, F., Mata, M.P., Morellón, M., Magri, D., Rodríguez-Lázaro, J., Carrión, J.S., 2014. Rapid climatic changes and resilient vegetation during the Lateglacial and Holocene in a continental region of south-western Europe. Global and Planetary Change 114, 50-65.

Baker, P.A., Seltzer, G.O., Fritz, S.C., Dunbar, R.B., Grove, M.J., Tapia, P.M., Cross, S.L., Rowe, H.D., Broda, J.P., 2001. The History of South American Tropical Precipitation for the Past 25,000 Years. Science 291, 640-643.

Ball, T., Chandler-Ezell, K., Dickau, R., Duncan, N., Hart, T.C., Iriarte, J., Lentfer, C., Logan, A., Lu, H., Madella, M., Pearsall, D.M., Piperno, D.R., Rosen, A.M., Vrydaghs, L., Weisskopf, A., Zhang, J., 2016. Phytoliths as a tool for investigations of agricultural origins and dispersals around the world. Journal of Archaeological Science 68, 32-45.

Barboni, D., Bremond, L., 2009. Phytoliths of East African grasses: An assessment of their environmental and taxonomic significance based on floristic data. Review of Palaeobotany and Palynology 158, 29-41.

Barboni, D., Bremond, L., Bonnefille, R., 2007. Comparative study of modern phytolith assemblages from inter-tropical Africa. Palaeogeography, Palaeoclimatology, Palaeoecology 246, 454-470.

Bartlein, P.J., Harrison, S.P., Brewer, S., Connor, S., Davis, B.A.S., Gajewski, K., Guiot, J., Harrison-Prentice, T.I., Henderson, A., Peyron, O., Prentice, I.C., Scholze, M., Seppä, H., Shuman, B., Sugita, S., Thompson, R.S., Viau, A.E., Williams, J., Wu, H., 2011. Pollenbased continental climate reconstructions at 6 and $21 \mathrm{ka}$ : a global synthesis. Climate Dynamics 37, 775-802.

Bayon, G., Dennielou, B., Etoubleau, J., Ponzevera, E., Toucanne, S., Bermell, S., 2012. Intensifying Weathering and Land Use in Iron Age Central Africa. Science 335, 1219-1222. Beaufort, L., de Garidel-Thoron, T., Linsley, B., Oppo, D., Buchet, N., 2003. Biomass burning and oceanic primary production estimates in the Sulu Sea area over the last $380 \mathrm{kyr}$ and the East Asian Monsoon Dynamics. Marine Geology 201, 53-65.

Behling, H., Safford, H.D., 2010. Late-glacial and Holocene vegetation, climate and fire dynamics in the Serra dos Órgãos, Rio de Janeiro State, southeastern Brazil. Global Change Biology 16, 1661-1671.

Bell, B.A., Fletcher, W.J., Ryan, P., Grant, H., Ilmen, R., 2017. Stable carbon isotope analysis of Cedrus atlantica pollen as an indicator of moisture availability. Review of Palaeobotany and Palynology 244, 128-139.

Bennett, K.D., Haberle, S.G., Lumley, S.H., 2000. The Last Glacial-Holocene Transition in Southern Chile. Science 290, 325. 
Bennett, K.D., Willis, K.J., 2000. Effect of global atmospheric carbon dioxide on glacialinterglacial vegetation change. Global Ecology and Biogeography 9, 355-361.

Bereiter, B., Eggleston, S., Schmitt, J., Nehrbass-Ahles, C., Stocker, T.F., Fischer, H., Kipfstuhl, S., Chappellaz, J., 2015. Revision of the EPICA Dome C CO2 record from 800 to 600 kyr before present. Geophysical Research Letters 42, 542-549.

Berger, A.L., 1978. Long-Term Variations of Daily Insolation and Quaternary Climatic Changes. Journal of the Atmospheric Sciences 35, 2362-2367.

Berrio, J.C., Hooghiemstra, H., Behling, H., Botero, P., Van der Borg, K., 2002. LateQuaternary savanna history of the Colombian Llanos Orientales from Lagunas Chenevo and Mozambique: a transect synthesis. The Holocene 12, 35-48.

Berrío, J.C., Hooghiemstra, H., Marchant, R., Rangel, O., 2002. Late-glacial and Holocene history of the dry forest area in the south Colombian Cauca Valley. Journal of Quaternary Science 17, 667-682.

Beug, H.-J., 2004. Leitfaden der Pollenbestimmung fur Mitteleuropa und angrenzende Gebiete. Verlag, Munich.

Bigelow, N.H., 2013. POLLEN RECORDS, LATE PLEISTOCENE | Northern North America. 39-51.

Bigelow, N.H., Brubaker, L.B., Edwards, M.E., Harrison, S.P., Prentice, I.C., Anderson, P.M., Andreev, A.A., Bartlein, P.J., Christensen, T.R., Cramer, W., Kaplan, J.O., Lozhkin, A.V., Matveyeva, N.V., Murray, D.F., McGuire, A.D., Razzhivin, V.Y., Ritchie, J.C., Smith, B., Walker, D.A., Gajewski, K., Wolf, V., Holmqvist, B.H., Igarashi, Y., Kremenetskii, K., Paus, A., Pisaric, M.F.J., Volkova, V.S., 2003. Climate change and Arctic ecosystems: 1.

Vegetation changes north of $55^{\circ} \mathrm{N}$ between the last glacial maximum, mid-Holocene, and present. J. Geophys. Res. Atmos. 108.

Binney, H., Edwards, M., Macias-Fauria, M., Lozhkin, A., Anderson, P., Kaplan, J.O., Andreev, A., Bezrukova, E., Blyakharchuk, T., Jankovska, V., Khazina, I., Krivonogov, S., Kremenetski, K., Nield, J., Novenko, E., Ryabogina, N., Solovieva, N., Willis, K., Zernitskaya, V., 2017. Vegetation of Eurasia from the last glacial maximum to present: Key biogeographic patterns. Quaternary Science Reviews 157, 80-97.

Bird, M.I., Cali, J.A., 1998. A million-year record of fire in sub-Saharan Africa. Nature 394, 767.

Bird, M.I., Cali, J.A., 2002. A revised high-resolution oxygen-isotope chronology for ODP668B: implications for Quaternary biomass burning in Africa. Global and Planetary Change 33, 73-76.

Birks, H.H., Ammann, B., 2000. Two terrestrial records of rapid climatic change during the glacial-Holocene transition (14,000-9,000 calendar years B.P.) from Europe. Proceedings of the National Academy of Sciences of the United States of America 97, 1390-1394.

Birks, H.J.B., 1986. Late-Quaternary biotic changes in terrestrial and lacustrine environments, with particular reference to north-west Europe, in: Berglund, B.E. (Ed.), Handbook of Holocene Palaeoecology and Palaeohydrology. John Wiley \& sons, pp. 3-65.

Birks, H.J.B., Berglund, B.E., 2018. One hundred years of Quaternary pollen analysis 19162016. Vegetation History and Archaeobotany 27, 271-309.

Birks, H.J.B., Birks, H.H., 1980. Quaternary Palaeoecology. Edward Arnold, London.

Birks, H.J.B., Birks, H.H., 2008. Biological responses to rapid climate change at the Younger Dryas-Holocene transition at Kråkenes, western Norway. The Holocene 18, 19-30. Biwolé, A.B., Morin-Rivat, J., Fayolle, A., Bitondo, D., Dedry, L., Dainou, K., Hardy, O.J., Doucet, J.-L., 2015. New data on the recent history of the littoral forests of southern Cameroon: an insight into the role of historical human disturbances on the current forest composition. Plant Ecology and Evolution 148, 19-28.

Blarquez, O., Aleman, J.C., 2016. Tree biomass reconstruction shows no lag in postglacial afforestation of eastern Canada. Canadian Journal of Forest Research 46, 485-498.

Blarquez, O., Ali, A.A., Girardin, M.P., Grondin, P., Fréchette, B., Bergeron, Y., Hély, C., 2015. Regional paleofire regimes affected by non-uniform climate, vegetation and human drivers. Scientific Reports 5, 13356. 
Blarquez, O., Vannière, B., Marlon, J.R., Daniau, A.-L., Power, M.J., Brewer, S., Bartlein, P.J., 2014. paleofire: An R package to analyse sedimentary charcoal records from the Global Charcoal Database to reconstruct past biomass burning. Computers \& Geosciences 72, 255261.

Bond, W.J., Woodward, F.I., Midgley, G.F., 2005. The global distribution of ecosystems in a world without fire. New Phytologist 165, 525-538.

Bostoen, K., Clist, B., Doumenge, C., Grollemund, R., Hombert, J.-M., Muluwa, J.K., Maley, J., 2015. Middle to Late Holocene Paleoclimatic Change and the Early Bantu Expansion in the Rain Forests of Western Central Africa. Current Anthropology 56, 354-384.

Bottema, S., van Straaten, L.M.J.U., 1966. Malacology and palynology of two cores from the Adriatic Sea floor. Marine Geology 4, 553-564.

Boulter, M.C., 1994. An approach to a standard terminology for palynodebris, in: Traverse, A. (Ed.), Sedimentation of orgaic particles. Cambridge University Press, Cambridge, pp. 199216.

Bowman, D.M.J.S., Balch, J.K., Artaxo, P., Bond, W.J., Carlson, J.M., Cochrane, M.A., D’Antonio, C.M., DeFries, R.S., Doyle, J.C., Harrison, S.P., Johnston, F.H., Keeley, J.E., Krawchuk, M.A., Kull, C.A., Marston, J.B., Moritz, M.A., Prentice, I.C., Roos, C.I., Scott, A.C., Swetnam, T.W., van der Werf, G.R., Pyne, S.J., 2009. Fire in the Earth System. Science 324, 481-484.

Bremond, L., Alexandre, A., Hély, C., Guiot, J., 2005a. A phytolith index as a proxy of tree cover density in tropical areas: calibration with Leaf Area Index along a forest-savanna transect in southeastern Cameroon. Global and Planetary Change 45, 277-293.

Bremond, L., Alexandre, A., Peyron, O., Guiot, J., 2005b. Grass water stress estimated from phytoliths in West Africa. Journal of Biogeography 32, 311-327.

Bremond, L., Alexandre, A., Wooller, M.J., Hély, C., Williamson, D., Schäfer, P.A., Majule, A., Guiot, J., 2008. Phytolith indices as proxies of grass subfamilies on East African tropical mountains. Global and Planetary Change 61, 209-224.

Bremond, L., Bodin, S.C., Bentaleb, I., Favier, C., Canal, S., 2017. Past tree cover of the Congo Basin recovered by phytoliths and $\delta 13 \mathrm{C}$ along soil profiles. Quaternary International 434, 91-101.

Brewer, S., Giesecke, T., Davis, B.A.S., Finsinger, W., Wolters, S., Binney, H., de Beaulieu, J.-L., Fyfe, R., Gil-Romera, G., Kühl, N., Kuneš, P., Leydet, M., Bradshaw, R.H., 2017. Lateglacial and Holocene European pollen data. Journal of Maps 13, 921-928.

Brewer, S., Guiot, J., Barboni, D., 2007. Pollen data as climate proxies, in: Elsevier (Ed.), Encyclopedia of Quaternary Science, pp. 2497-2508.

Broström, A., Nielsen, A.B., Gaillard, M.-J., Hjelle, K., Mazier, F., Binney, H., Bunting, J., Fyfe, R., Meltsov, V., Poska, A., Räsänen, S., Soepboer, W., von Stedingk, H., Suutari, H., Sugita, S., 2008. Pollen productivity estimates of key European plant taxa for quantitative reconstruction of past vegetation: a review. Vegetation History and Archaeobotany 17, 461478.

Bunting, M.J., Farrell, M., Broström, A., Hjelle, K.L., Mazier, F., Middleton, R., Nielsen, A.B., Rushton, E., Shaw, H., Twiddle, C.L., 2013. Palynological perspectives on vegetation survey: A critical step for model-based reconstruction of Quaternary land cover. Quaternary Science Reviews 82, 41-55.

Bunting, M.J., Gaillard, M.J., Sugita, S., Middleton, R., Broström, A., 2004. Vegetation structure and pollen source area. Holocene 14, 651-660.

Burbridge, R.E., Mayle, F.E., Killeen, T.J., 2004. Fifty-thousand-year vegetation and climate history of Noel Kempff Mercado National Park, Bolivian Amazon. Quaternary Research 61, 215-230.

Burjachs, F., Jones, S.E., Giralt, S., Fernández-López de Pablo, J., 2016. Lateglacial to Early Holocene recursive aridity events in the SE Mediterranean Iberian Peninsula: The Salines playa lake case study. Quaternary International 403, 187-200.

Bush, M.B., Miller, M.C., De Oliveira, P.E., Colinvaux, P.A., 2000. Two histories of environmental change and human disturbance in eastern lowland Amazonia. Holocene 10, 543-553. 
Bush, M.B., Silman, M.R., de Toledo, M.B., Listopad, C., Gosling, W.D., Williams, C., de Oliveira, P.E., Krisel, C., 2007. Holocene fire and occupation in Amazonia: records from two lake districts. Philosophical Transactions of the Royal Society B: Biological Sciences 362, 209-218.

Bush, M.B., Weng, C., 2007. Introducing a new (freeware) tool for palynology. Journal of Biogeography 34, 377-380.

Campbell, J.F.E., Fletcher, W.J., Hughes, P.D., Shuttleworth, E.L., 2016. A comparison of pollen extraction methods confirms dense-media separation as a reliable method of pollen preparation. Journal of Quaternary Science 31, 631-640.

Campbell, J.F.E., Fletcher, W.J., Joannin, S., Hughes, P.D., Rhanem, M., Zielhofer, C., 2017. Environmental Drivers of Holocene Forest Development in the Middle Atlas, Morocco. Frontiers in Ecology and Evolution 5.

Carcaillet, C., Bouvier, M., Fréchette, B., Larouche, A.C., Richard, P.J.H., 2001. Comparison of pollen-slide and sieving methods in lacustrine charcoal analyses for local and regional fire history. The Holocene 11, 467-476.

Carrión, J.S., 2002. Patterns and processes of Late Quaternary environmental change in a montane region of southwestern Europe. Quaternary Science Reviews 21, 2047-2066.

Carrión, J.S., Fernández, S., Jiménez-Moreno, G., Fauquette, S., Gil-Romera, G., GonzálezSampériz, P., Finlayson, C., 2010. The historical origins of aridity and vegetation degradation in southeastern Spain. Journal of Arid Environments 74, 731-736.

Carrión, J.S., Sánchez-Gómez, P., Mota, J.F., YII, R., Chaín, C., 2003. Holocene vegetation dynamics, fire and grazing in the Sierra de Gádor, southern Spain. Holocene 13, 839-849.

Cassino, R., Meyer, K.E.B., 2011. Morfologia de grãos de pólen e esporos de níveis holocênicos de uma vereda do Chapadão dos Gerais (Buritizeiro, Minas Gerais), Brasil. Gaea-Journal of Geoscience 7, 41-70.

Chabaud, L., Sánchez Goñi, M.F., Desprat, S., Rossignol, L., 2014. Land-sea climatic variability in the eastern North Atlantic subtropical region over the last 14,200 years: Atmospheric and oceanic processes at different timescales. The Holocene 24, 787-797. Chevalier, M., Cheddadi, R., Chase, B.M., 2014. CREST (Climate REconstruction SofTware): a probability density function (PDF)-based quantitative climate reconstruction method. Clim. Past 10, 2081-2098.

Chmura, G.L., Smirnov, A., Campbell, I.D., 1999. Pollen transport through distributaries and depositional patterns in coastal waters. Palaeogeography, Palaeoclimatology, Palaeoecology $149,257-270$.

Clark, J.S., 1988. Particle motion and the theory of charcoal analysis: source area, transport, deposition, and sampling. Quaternary Research 30, 67-80.

Clark, J.S., Hussey, T.C., 1996. Estimating the mass flux of charcoal from sedimentary records: effects of particle size, morphology, and orientation. The Holocene 6, 129-144. Clark, J.S., Merkt, J., Muller, H., 1989. Post-Glacial Fire, Vegetation, and Human History on the Northern Alpine Forelands, South-Western Germany. Journal of Ecology 77, 897-925. Clark, P.U., Archer, D., Pollard, D., Blum, J.D., Rial, J.A., Brovkin, V., Mix, A.C., Pisias, N.G., Roy, M., 2006. The middle Pleistocene transition: characteristics, mechanisms, and implications for long-term changes in atmospheric pCO2. Quaternary Science Reviews 25, 3150-3184.

Clark, R., 1984. Effects on charcoal of pollen preparation procedures. Pollen et Spores 26, 559-576.

Clark, R.L., 1982. Point count estimation of charcoal in pollen preparations and thin sections of sediments. Pollen et Spores 24, 523-535.

Colinvaux, P.A., De Oliveira, P.E., Moreno, J.E., 1999. Amazon Pollen Manual and Atlas. Harwood Academic Press, New York.

Collins, P.M., Davis, B.A.S., Kaplan, J.O., 2012. The mid-Holocene vegetation of the Mediterranean region and southern Europe, and comparison with the present day. Journal of Biogeography 39, 1848-1861. 
Colombaroli, D., Marchetto, A., Tinner, W., 2007. Long-term interactions between Mediterranean climate, vegetation and fire regime at Lago di Massaciuccoli (Tuscany, Italy). Journal of Ecology 95, 755-770.

Conedera, M., Tinner, W., Neff, C., Meurer, M., Dickens, A.F., Krebs, P., 2009.

Reconstructing past fire regimes: methods, applications, and relevance to fire management and conservation. Quaternary Science Reviews 28, 555-576.

Cornell, S.E., Prentice, C.I., House, J.I., Downy, C.J., 2012. Understanding the Earth System. Global Change Science for Application. Cambridge University Press.

Correa-Metrio, A., Bush, M.B., Cabrera, K.R., Sully, S., Brenner, M., Hodell, D.A., Escobar, J., Guilderson, T., 2012. Rapid climate change and no-analog vegetation in lowland Central America during the last 86,000 years. Quaternary Science Reviews 38, 63-75.

Courtney Mustaphi, C.J., Pisaric, M.F., 2014. A classification for macroscopic charcoal morphologies found in Holocene lacustrine sediments. Progress in Physical Geography 38, 734-754.

Crawford, A.J., Belcher, C.M., 2014. Charcoal morphometry for paleoecological analysis: The effects of fuel type and transportation on morphological parameters. Applications in Plant Sciences 2, apps.1400004.

Cui, Q.Y., Gaillard, M.J., Lemdahl, G., Stenberg, L., Sugita, S., Zernova, G., 2014. Historical land-use and landscape change in southern Sweden and implications for present and future biodiversity. Ecol Evol 4, 3555-3570.

Daniau, A.-L., Bartlein, P.J., Harrison, S.P., Prentice, I.C., Brewer, S., Friedlingstein, P., Harrison-Prentice, T.I., Inoue, J., Izumi, K., Marlon, J.R., Mooney, S., Power, M.J., Stevenson, J., Tinner, W., Andrič, M., Atanassova, J., Behling, H., Black, M., Blarquez, O., Brown, K.J., Carcaillet, C., Colhoun, E.A., Colombaroli, D., Davis, B.A.S., D'Costa, D., Dodson, J., Dupont, L., Eshetu, Z., Gavin, D.G., Genries, A., Haberle, S., Hallett, D.J., Hope, G., Horn, S.P., Kassa, T.G., Katamura, F., Kennedy, L.M., Kershaw, P., Krivonogov, S., Long, C., Magri, D., Marinova, E., McKenzie, G.M., Moreno, P.I., Moss, P., Neumann, F.H., Norström, E., Paitre, C., Rius, D., Roberts, N., Robinson, G.S., Sasaki, N., Scott, L., Takahara, H., Terwilliger, V., Thevenon, F., Turner, R., Valsecchi, V.G., Vannière, B., Walsh, M., Williams, N., Zhang, Y., 2012. Predictability of biomass burning in response to climate changes. Global Biogeochemical Cycles 26.

Daniau, A.-L., Harrison, S.P., Bartlein, P.J., 2010. Fire regimes during the last glacial.

Quaternary Science Reviews 29, 2918-2930

Daniau, A.-L., Sánchez-Goñi, M.F., Duprat, J., 2009. Last glacial fire regime variability in western France inferred from microcharcoal preserved in core MD04-2845, Bay of Biscay. Quaternary Research 71, 385-396.

Daniau, A.-L., Sanchez Goñi, M.F., Martinez, P., Urrego, D.H., Bout-Roumazeilles, V., Desprat, S., Marlon, J.R., 2013. Orbital-scale climate forcing of grassland burning in southern Africa. Proceedings of the National Academy of Sciences 110, 5069-5073.

Daniau, A.L., Sanchez Goñi, M.-F., Beaufort, L., Laggoun-Défarge, F., Loutre, M.-F., Duprat, J., 2007. Dansgaard-Oeschger climatic variability revealed by fire emissions in southwestern Iberia. Quaternary Science Reviews 26, 1369-1383.

Davis, B.A.S., Brewer, S., 2009. Orbital forcing and role of the latitudinal insolation/temperature gradient. Climate Dynamics 32, 143-165.

Davis, B.A.S., Brewer, S., Stevenson, A.C., Guiot, J., 2003a. The temperature of Europe during the Holocene reconstructed from pollen data. Quaternary Science Reviews 22, 17011716.

Davis, B.A.S., Brewer, S., Stevenson, A.C., Guiot, J., 2003b. The temperature of Europe during the Holocene reconstructed from pollen data. Quaternary Science Reviews 22, 17011716.

Davis, B.A.S., Collins, P.M., Kaplan, J.O., 2015. The age and post-glacial development of the modern European vegetation: a plant functional approach based on pollen data. Vegetation History and Archaeobotany 24, 303-317.

Davis, B.A.S., Zanon, M., Collins, P., Mauri, A., Bakker, J., Barboni, D., Barthelmes, A., Beaudouin, C., Bjune, A.E., Bozilova, E., Bradshaw, R.H.W., Brayshay, B.A., Brewer, S., 
Brugiapaglia, E., Bunting, J., Connor, S.E., Beaulieu, J.-L., Edwards, K., Ejarque, A., Fall, P., Florenzano, A., Fyfe, R., Galop, D., Giardini, M., Giesecke, T., Grant, M.J., Guiot, J., Jahns, S., Jankovská, V., Juggins, S., Kahrmann, M., Karpińska-Kołaczek, M., Kołaczek, P., Kühl, N., Kuneš, P., Lapteva, E.G., Leroy, S.A.G., Leydet, M., Guiot, J., López Sáez, J.A., Masi, A., Matthias, I., Mazier, F., Meltsov, V., Mercuri, A.M., Miras, Y., Mitchell, F.J.G., Morris, J.L., Naughton, F., Nielsen, A.B., Novenko, E., Odgaard, B., Ortu, E., Overballe-Petersen, M.V., Pardoe, H.S., Peglar, S.M., Pidek, I.A., Sadori, L., Seppä, H., Severova, E., Shaw, H., Święta-Musznicka, J., Theuerkauf, M., Tonkov, S., Veski, S., Knaap, W.O., Leeuwen, J.F.N., Woodbridge, J., Zimny, M., Kaplan, J.O., 2013. The European Modern Pollen Database (EMPD) project. Vegetation History and Archaeobotany 22, 521-530.

Davis, M.B., 1984. Holocene vegetational history of the eastern United States. LateQuaternary environments of the United States. Vol. 2, 166-181.

Davis, M.B., 2015. Phytogeography and palynology of Northeastern United States, The Quaternary of the U.S., pp. 377-401.

de Beaulieu, J.-L., Andrieu-Ponel, V., Reille, M., Grüger, E., Tzedakis, C., Svobodova, H., 2001. An attempt at correlation between the Velay pollen sequence and the Middle Pleistocene stratigraphy from central Europe. Quaternary Science Reviews 20, 1593-1602. de Beaulieu, J.L., Tzedakis, P.C., Andrieu-Ponel, V., Guiter, F., 2013. Pollen records, Late Pleitocene | Middle and Late Pleistocene in Southern Europe, in: Elias, S.A., Mock, C.J. (Eds.), Encyclopedia of Quaternary Science (Second Edition). Elsevier, Amsterdam, pp. 6371.

de Vernal, A., Hillaire-Marcel, C., 2006. Provincialism in trends and high frequency changes in the northwest North Atlantic during the Holocene. Global and Planetary Change 54, 263290.

de Vernal, A., Hillaire-Marcel, C., 2008. Natural variability of Greenland climate, vegetation, and ice volume during the past million years. Science 320, 1622-1625.

deMenocal, P., Ortiz, J., Guilderson, T., Adkins, J., Sarnthein, M., Baker, L., Yarusinsky, M., 2000. Abrupt onset and termination of the African Humid Period:: rapid climate responses to gradual insolation forcing. Quaternary Science Reviews 19, 347-361.

Demske, D., Tarasov, P.E., Nakagawa, T., 2013. Atlas of pollen, spores and further nonpollen palynomorphs recorded in the glacial-interglacial late Quaternary sediments of Lake Suigetsu, central Japan. Quaternary International 290-291, 164-238.

Desprat, S., 2005. Réponses climatiques marines et continentales du Sud-Ouest de l'Europe lors des derniers interglaciaires et des entrées en glaciations., Département de Géologie et Océanographie. Université Bordeaux I, Talence, p. 282.

Desprat, S., Combourieu-Nebout, N., Essallami, L., Sicre, M.A., Dormoy, I., Peyron, O., Siani, G., Bout Roumazeilles, V., Turon, J.L., 2013. Deglacial and Holocene vegetation and climatic changes in the southern Central Mediterranean from a direct land-sea correlation.

Clim. Past 9, 767-787.

Desprat, S., Díaz Fernández, P.M., Coulon, T., Ezzat, L., Pessarossi-Langlois, J., Gil, L., Morales-Molino, C., Sánchez Goñi, M.F., 2015. Pinus nigra (European black pine) as the dominant species of the last glacial pinewoods in south-western to central lberia: a morphological study of modern and fossil pollen. Journal of Biogeography 42, 1998-2009. Desprat, S., Oliveira, D., Naughton, F., Goñi, M.F.S., 2017. Pollen in marine sedimentary archives, a key for climate studies: The example of past warm periods. Quaternaire 28, 259269.

Di Rita, F., Fletcher, W.J., Aranbarri, J., Margaritelli, G., Lirer, F., Magri, D., 2018. Holocene forest dynamics in central and western Mediterranean: periodicity, spatio-temporal patterns and climate influence. Scientific Reports 8, 8929.

Doyen, E., Vannière, B., Bichet, V., Gauthier, E., Richard, H., Petit, C., 2013. Vegetation history and landscape management from 6500 to 1500 cal. b.p. at Lac d'Antre, Gallo-Roman sanctuary of Villards d'Héria, Jura, France. Vegetation History and Archaeobotany 22, 83-97. Dunn, R.E., Strömberg, C.A.E., Madden, R.H., Kohn, M.J., Carlini, A.A., 2015. Linked canopy, climate, and faunal change in the Cenozoic of Patagonia. Science 347, 258-261. 
Dupont, L., 2011. Orbital scale vegetation change in Africa. Quaternary Science Reviews 30, 3589-3602.

Dupont, L., Wyputta, U., 2003. Reconstructing pathways of aeolian pollen transport to the marine sediments along the coastline of SW Africa. Quaternary Science Reviews 22, 157 174.

Dupont, L.M., Agwu, C.O.C., 1992. Latitudinal shifts of forest and savanna in N. W. Africa during the Brunhes chron: further marine palynological results from site $\mathrm{M} 16415\left(9^{\circ}\right.$; $\mathrm{N}$ $\left.19^{\circ} \mathrm{W}\right)$. Vegetation History and Archaeobotany 1, 163-175.

Dupont, L.M., Donner, B., Schneider, R., Wefer, G., 2001. Mid-Pleistocene environmental change in tropical Africa began as early as $1.05 \mathrm{Ma}$. Geology 29, 195-198.

Dupont, L.M., Jahns, S., Marret, F., Ning, S., 2000. Vegetation change in equatorial West Africa: time-slices for the last $150 \mathrm{ka}$. Palaeogeography, Palaeoclimatology, Palaeoecology $155,95-122$.

Duprat-Oualid, F., Rius, D., Bégeot, C., Magny, M., Millet, L., Wulf, S., Appelt, O., 2017. Vegetation response to abrupt climate changes in Western Europe from 45 to $14.7 \mathrm{k}$ cal a BP: the Bergsee lacustrine record (Black Forest, Germany). Journal of Quaternary Science 32, 1008-1021.

Elenga, H., Schwartz, D., Vincens, A., 1994. Pollen evidence of late Quaternary vegetation and inferred climate changes in Congo. Palaeogeography, Palaeoclimatology, Palaeoecology 109, 345-356.

Erdtman, G., 1954. An introduction to pollen analysis. The Chronica Botanica Company, Waltham.

Faegri, K., Iversen, J., 1964. Textbook of pollen analysis. Munksgaard, Copenhagen. Faucon, M.-P., Houben, D., Lambers, H., 2017. Plant Functional Traits: Soil and Ecosystem Services. Trends in Plant Science 22, 385-394.

Feurdean, A., Gałka, M., Tanţău, I., Geantă, A., Hutchinson, S.M., Hickler, T., 2016. Tree and timberline shifts in the northern Romanian Carpathians during the Holocene and the responses to environmental changes. Quaternary Science Reviews 134, 100-113. Feurdean, A., Perşoiu, A., Tanţău, I., Stevens, T., Magyari, E.K., Onac, B.P., Marković, S., Andrič, M., Connor, S., Fărcaş, S., Gałka, M., Gaudeny, T., Hoek, W., Kolaczek, P., Kuneš, P., Lamentowicz, M., Marinova, E., Michczyńska, D.J., Perşoiu, I., Płóciennik, M., Słowiński, M., Stancikaite, M., Sumegi, P., Svensson, A., Tămaş, T., Timar, A., Tonkov, S., Toth, M., Veski, S., Willis, K.J., Zernitskaya, V., 2014. Climate variability and associated vegetation response throughout Central and Eastern Europe (CEE) between 60 and 8 ka. Quaternary Science Reviews 106, 206-224.

Finsinger, W., Tinner, W., 2005. Minimum count sums for charcoal concentration estimates in pollen slides: accuracy and potential errors. The Holocene 15, 293-297.

Fischer, H., Schüpbach, S., Gfeller, G., Bigler, M., Röthlisberger, R., Erhardt, T., Stocker, T.F., Mulvaney, R., Wolff, E.W., 2015. Millennial changes in North American wildfire and soil activity over the last glacial cycle. Nature Geoscience 8, 723.

Flantua, S.G.A., Hooghiemstra, H., Grimm, E.C., Behling, H., Bush, M.B., González-Arango, C., Gosling, W.D., Ledru, M.P., Lozano-García, S., Maldonado, A., Prieto, A.R., Rull, V., Van Boxel, J.H., 2015. Updated site compilation of the Latin American Pollen Database. Review of Palaeobotany and Palynology 223, 104-115.

Fleitmann, D., Cheng, H., Badertscher, S., Edwards, R.L., Mudelsee, M., Göktürk, O.M., Fankhauser, A., Pickering, R., Raible, C.C., Matter, A., Kramers, J., Tüysüz, O., 2009. Timing and climatic impact of Greenland interstadials recorded in stalagmites from northern Turkey. Geophysical Research Letters 36.

Fletcher, M.S., Moreno, P.I., 2011. Zonally symmetric changes in the strength and position of the Southern Westerlies drove atmospheric CO<inf $>2<$ inf $>$ variations over the past 14 k.y. Geology 39, 419-422.

Fletcher, W.J., Faust, D., Zielhofer, C., 2013. Fragile landscape systems. CATENA 103, 1-2. Fletcher, W.J., Sanchez Goñi, M.F., 2008. Orbital- and sub-orbital-scale climate impacts on vegetation of the western

Mediterranean basin over the last 48,000 yr. Quaternary Research 70 451-464. 
Fletcher, W.J., Sánchez Goñi, M.F., Allen, J.R.M., Cheddadi, R., Combourieu-Nebout, N., Huntley, B., Lawson, I., Londeix, L., Magri, D., Margari, V., Müller, U.C., Naughton, F., Novenko, E., Roucoux, K., Tzedakis, P.C., 2010. Millennial-scale variability during the last glacial in vegetation records from Europe. Quaternary Science Reviews 29, 2839-2864.

Foley, J.A., Costa, M.H., Delire, C., Ramankutty, N., Snyder, P., 2003. Green surprise? How terrestrial ecosystems could affect earth's climate. Frontiers in Ecology and the Environment 1, 38-44.

Follieri, M., Magri, D., Sadori, L., 1988. 250.000-year pollen record from valle di Castiglione (Roma). Pollen et Spores 30, 329-356.

Fontana, S.L., Bennett, K.D., 2012. Postglacial vegetation dynamics of western Tierra del Fuego†. Holocene 22, 1337-1350.

Francois, R., Frank, M., Rutgers van der Loeff, M.M., Bacon, M.P., 2004. 230Th normalization: An essential tool for interpreting sedimentary fluxes during the late Quaternary. Paleoceanography 19.

Fredlund, G.G., Tieszen, L.T., 1994. Modern Phytolith Assemblages from the North American Great Plains. Journal of Biogeography 21, 321-335.

Fujiki, T., Zhou, Z., Yasuda, Y., 2005. The Pollen Flora of Yunnan, China. Roli Books, New Delhi, India.

Fyfe, R., Roberts, N., Woodbridge, J., 2010. A pollen-based pseudobiomisation approach to anthropogenic land-cover change. The Holocene 20, 1165-1171.

Fyfe, R.M., de Beaulieu, J.-L., Binney, H., Bradshaw, R.H.W., Brewer, S., Le Flao, A., Finsinger, W., Gaillard, M.-J., Giesecke, T., Gil-Romera, G., Grimm, E.C., Huntley, B., Kunes, P., Kühl, N., Leydet, M., Lotter, A.F., Tarasov, P.E., Tonkov, S., 2009. The European Pollen Database: past efforts and current activities. Vegetation History and Archaeobotany 18, 417-424.

Fyfe, R.M., Twiddle, C., Sugita, S., Gaillard, M.-J., Barratt, P., Caseldine, C.J., Dodson, J., Edwards, K.J., Farrell, M., Froyd, C., Grant, M.J., Huckerby, E., Innes, J.B., Shaw, H., Waller, M., 2013. The Holocene vegetation cover of Britain and Ireland: overcoming problems of scale and discerning patterns of openness. Quaternary Science Reviews 73, 132-148. Fyfe, R.M., Woodbridge, J., Roberts, N., 2015. From forest to farmland: pollen-inferred land cover change across Europe using the pseudobiomization approach. Global Change Biology 21, 1197-1212.

Gaceur, E., Desprat, S., Rouis-Zargouni, I., Hanquiez, V., Lebreton, V., Combourieu Nebout, N., Kallel, N., 2017. Pollen distribution in surface sediments of the northern Lower Medjerda valley (northeastern Tunisia). Review of Palaeobotany and Palynology 247, 13-25.

Gaillard, M.-J., Morrison, K.D., Madella, M., Whitehouse, N., 2018. Past land-use and landcover change: the challenge of quantification at the subcontinental to global scales. PAGES Magazine 26.

Gaillard, M.-J., Sugita, S., Bunting, M.J., Middleton, R., Broström, A., Caseldine, C., Giesecke, T., Hellman, S.E.V., Hicks, S., Hjelle, K., Langdon, C., Nielsen, A.-B., Poska, A., von Stedingk, H., Veski, S., 2008. The use of modelling and simulation approach in reconstructing past landscapes from fossil pollen data: a review and results from the POLLANDCAL network. Vegetation History and Archaeobotany 17, 419-443.

Gaillard, M.J., Sugita, S., Mazier, F., Trondman, A.K., Broström, A., Hickler, T., Kaplan, J.O., Kjellström, E., Kokfelt, U., Kuneš, P., Lemmen, C., Miller, P., Olofsson, J., Poska, A., Rundgren, M., Smith, B., Strandberg, G., Fyfe, R., Nielsen, A.B., Alenius, T., Balakauskas, L., Barnekow, L., Birks, H.J.B., Bjune, A., Björkman, L., Giesecke, T., Hjelle, K., Kalnina, L., Kangur, M., van der Knaap, W.O., Koff, T., Lagerås, P., Latałowa, M., Leydet, M., Lechterbeck, J., Lindbladh, M., Odgaard, B., Peglar, S., Segerström, U., von Stedingk, H., Seppä, H., 2010. Holocene land-cover reconstructions for studies on land cover-climate feedbacks. Climate of the Past 6, 483-499.

Gajewski, K., Lézine, A.M., Vincens, A., Delestan, A., Sawada, M., 2002. Modern climatevegetation-pollen relations in Africa and adjacent areas. Quaternary Science Reviews 21, 1611-1631. 
Garcin, Y., Deschamps, P., Ménot, G., de Saulieu, G., Schefuß, E., Sebag, D., Dupont, L.M., Oslisly, R., Brademann, B., Mbusnum, K.G., Onana, J.-M., Ako, A.A., Epp, L.S., Tjallingii, R., Strecker, M.R., Brauer, A., Sachse, D., 2018. Early anthropogenic impact on Western Central African rainforests 2,600 y ago. Proceedings of the National Academy of Sciences. Garnier, A., Neumann, K., Eichhorn, B., Lespez, L., 2012. Phytolith taphonomy in the middleto late-Holocene fluvial sediments of Ounjougou (Mali, West Africa). The Holocene 23, 416431.

Garreaud, R.D., Vuille, M., Compagnucci, R., Marengo, J., 2009. Present-day South American climate. Palaeogeography, Palaeoclimatology, Palaeoecology 281, 180-195. Gavin, D.G., Hu, F.S., 2013. POLLEN RECORDS, POSTGLACIAL | Northwestern North America, in: Elias, S.A., Mock, C.J. (Eds.), Encyclopedia of Quaternary Science (Second Edition). Elsevier, Amsterdam, pp. 124-132.

Ghilardi, B., O'Connell, M., 2013. Early Holocene vegetation and climate dynamics with particular reference to the 8.2 ka event: pollen and macrofossil evidence from a small lake in western Ireland. Vegetation History and Archaeobotany 22, 99-114.

Giesecke, T., Davis, B., Brewer, S., Finsinger, W., Wolters, S., Blaauw, M., de Beaulieu, J.L., Binney, H., Fyfe, R.M., Gaillard, M.-J., Gil-Romera, G., van der Knaap, W.O., Kuneš, P., Kühl, N., van Leeuwen, J.F.N., Leydet, M., Lotter, A.F., Ortu, E., Semmler, M., Bradshaw, R.H.W., 2014. Towards mapping the late Quaternary vegetation change of Europe. Vegetation History and Archaeobotany 23, 75-86.

Giesecke, T., Hickler, T., Kunkel, T., Sykes, M.T., Bradshaw, R.H.W., 2007. ORIGINAL ARTICLE: Towards an understanding of the Holocene distribution of Fagus sylvatica $L$. Journal of Biogeography 34, 118-131.

Gil-Romera, G., Carrión, J.S., Pausas, J.G., Sevilla-Callejo, M., Lamb, H.F., Fernández, S., Burjachs, F., 2010. Holocene fire activity and vegetation response in South-Eastern Iberia. Quaternary Science Reviews 29, 1082-1092.

Giresse, P., Maley, J., Doumenge, C., Philippon, N., Mahé, G., Chepstow-Lusty, A., Aleman, J., Lokonda, M., Elenga, H., 2018. Paleoclimatic changes are the most probable causes of the rainforest crises 2,600 y ago in Central Africa. Proceedings of the National Academy of Sciences 115, E6672.

Gosling, W.D., Miller, C.S., Livingstone, D.A., 2013. Atlas of the tropical West African pollen flora. Review of Palaeobotany and Palynology 199, 1-135.

Gosling William, D., Hanselman Jennifer, A., Knox, C., Valencia Bryan, G., Bush Mark, B., 2009. Long-term drivers of change in Polylepis woodland distribution in the central Andes. Journal of Vegetation Science 20, 1041-1052.

Grimm, E.C., 2006. Evidence for warm wet Heinrich events in Florida. Quaternary Science Reviews 25, 2197-2211.

Grimm, E.C., Jacobson Jr, J.L., 2004. Late-Quaternary vegetation history of the eastern United States, in: Gillepsie, A.R., Porter, S.C., Awater, B.F. (Eds.), The Quaternary period in United States. Elsevier, pp. 381-402.

Grollemund, R., Branford, S., Bostoen, K., Meade, A., Venditti, C., Pagel, M., 2015. Bantu expansion shows that habitat alters the route and pace of human dispersals. Proceedings of the National Academy of Sciences 112, 13296-13301.

Groot, J.J., Groot, C.R., 1966. Marine palynology: Possibilities, limitations, problems. Marine Geology 4, 387-395.

Groot, M.H.M., Bogotá, R.G., Lourens, L.J., Hooghiemstra, H., Vriend, M., Berrio, J.C., Tuenter, E., Van Der Plicht, J., Van Geel, B., Ziegler, M., Weber, S.L., Betancourt, A., Contreras, L., Gaviria, S., Giraldo, C., González, N., Jansen, J.H.F., Konert, M., Ortega, D., Rangel, O., Sarmiento, G., Vandenberghe, J., Van Der Hammen, T., Van Der Linden, M., Westerhoff, W., 2011. Ultra-high resolution pollen record from the northern Andes reveals rapid shifts in montane climates within the last two glacial cycles. Climate of the Past 7, 299316.

Gu, Y., Pearsall, D.M., Xie, S., Yu, J., 2008. Vegetation and fire history of a Chinese site in southern tropical Xishuangbanna derived from phytolith and charcoal records from Holocene sediments. Journal of Biogeography 35, 325-341. 
Guillet, B., Achoundong, G., Happi, J.Y., Beyala, V.K.K., Bonvallot, J., Riera, B., Mariotti, A., Schwartz, D., 2001. Agreement between floristic and soil organic carbon isotope (13C/12C, $14 \mathrm{C}$ ) indicators of forest invasion of savannas during the last century in Cameroon. Journal of Tropical Ecology 17, 809-832.

Haas, J.N., Richoz, I., Tinner, W., Wick, L., 1998. Synchronous Holocene climatic oscillations recorded on the Swiss Plateau and at timberline in the Alps. The Holocene 8, 301-309.

Haberle, S.G., Bennett, K.D., 2004. Postglacial formation and dynamics of North Patagonian Rainforest in the Chonos Archipelago, Southern Chile. Quaternary Science Reviews 23, 2433-2452.

Habib, D., Eshet, Y., Van Pelt, R., 1994. Palynology of sedimentary cycles, in: Traverse, A. (Ed.), Sedimentation of organic particles. Cambridge University Press, Cambridge, pp. 311336.

Hanselman, J.A., Bush, M.B., Gosling, W.D., Collins, A., Knox, C., Baker, P.A., Fritz, S.C., 2011. A 370,000-year record of vegetation and fire history around Lake Titicaca (Bolivia/Peru). Palaeogeography, Palaeoclimatology, Palaeoecology 305, 201-214. Hansen, J., Sato, M., Ruedy, R., Lo, K., Lea, D.W., Medina-Elizade, M., 2006. Global temperature change. Proceedings of the National Academy of Sciences 103, 14288-14293. Harrison, S., Goñi, M.S., 2010. Global patterns of vegetation response to millennial-scale variability and rapid climate change during the last glacial period. Quaternary Science Reviews 29, 2957-2980.

Harrison, S.P., Kutzbach, J.E., Prentice, I.C., Behling, P.J., Sykes, M.T., 1995. The Response of Northern Hemisphere Extratropical Climate and Vegetation to Orbitally Induced Changes in Insolation during the Last Interglaciation. Quaternary Research 43, 174-184. Harrison, S.P., Marlon, J.R., Bartlein, P.J., 2010. Fire in the Earth System, in: Dodson, J. (Ed.), Changing Climates, Earth Systems and Society. Springer International Year of Planet Earth book, p. 360.

Harrison, S.P., Prentice, C.I., 2003. Climate and $\mathrm{CO}_{2}$ controls on global vegetation distribution at the last glacial maximum: analysis based on palaeovegetation data, biome modelling and palaeoclimate simulations. Global Change Biology 9, 983-1004.

Hart, G.F., Pasley, M.A., Gregory, W.A., 1994. Sequence stratigraphy and sedimentation of organic particles, in: Traverse, A. (Ed.), Sedimentation of organic particles. Cambridge University Press, Cambridge, pp. 337-390.

Havinga, A.J., 1984. A 20 -year experimental investigation into the differential corrosion susceptibility of pollen and spores in various soil types. Pollen et Spores 26, 541-558. Hawthorne, D., Courtney Mustaphi, C.J., Aleman, J.C., Blarquez, O., Colombaroli, D., Daniau, A.-L., Marlon, J.R., Power, M., Vannière, B., Han, Y., Hantson, S., Kehrwald, N., Magi, B., Yue, X., Carcaillet, C., Marchant, R., Ogunkoya, A., Githumbi, E.N., Muriuki, R.M., 2018. Global Modern Charcoal Dataset (GMCD): A tool for exploring proxy-fire linkages and spatial patterns of biomass burning. Quaternary International 488, 3-17.

Hays, J.D., Imbrie, J., Shackelton, N.J., 1976. Variations in the Earth's Orbit Pacemaker of the Ice Ages. Science 194, 1121-1132.

Haywood, A.M., Hill, D.J., Dolan, A.M., Otto-Bliesner, B.L., Bragg, F., Chan, W.L., Chandler, M.A., Contoux, C., Dowsett, H.J., Jost, A., Kamae, Y., Lohmann, G., Lunt, D.J., Abe-Ouchi, A., Pickering, S.J., Ramstein, G., Rosenbloom, N.A., Salzmann, U., Sohl, L., Stepanek, C., Ueda, H., Yan, Q., Zhang, Z., 2013. Large-scale features of Pliocene climate: results from the Pliocene Model Intercomparison Project. Clim. Past 9, 191-209.

Hellman, S., Gaillard, M.-J., Broström, A., Sugita, S., 2008a. The REVEALS model, a new tool to estimate past regional plant abundance from pollen data in large lakes: validation in southern Sweden. Journal of Quaternary Science 23, 21-42.

Hellman, S.E.V., Gaillard, M.-j., Broström, A., Sugita, S., 2008b. Effects of the sampling design and selection of parameter values on pollen-based quantitative reconstructions of regional vegetation: a case study in southern Sweden using the REVEALS model.

Vegetation History and Archaeobotany 17, 445-459.

Henne, P., Elkin, C., Colombaroli, D., Samartin, S., Bugmann, H., Heiri, O., Tinner, W., 2013. Impacts of changing climate and land use on vegetation dynamics in a Mediterranean 
ecosystem: insights from paleoecology and dynamic modeling. Landscape Ecology 28, 819833.

Henríquez, W.I., Moreno, P.I., Alloway, B.V., Villarosa, G., 2015. Vegetation and climate change, fire-regime shifts and volcanic disturbance in Chiloé Continental $\left(43^{\circ} \mathrm{S}\right)$ during the last 10,000 years. Quaternary Science Reviews 123, 158-167.

Hesse, M., Zetter, R., Halbritter, H., Weber, M., Buchner, R., Frosch-Radivo, A., Ulrich, S., 2009. Pollen Terminology. An illustrated Handbook. Springer-Verlag/Wien, Austria.

Hessler, I., Dupont, L., Bonnefille, R., Behling, H., González, C., Helmens, K.F., Hooghiemstra, H., Lebamba, J., Ledru, M.-P., Lezine, A.-M., 2010a. Millennial-scale changes in vegetation records from tropical Africa and South America during the last glacial.

Quaternary Science Reviews 29, 2882-2899.

Hessler, I., Dupont, L., Bonnefille, R., Behling, H., González, C., Helmens, K.F., Hooghiemstra, H., Lebamba, J., Ledru, M.-P., Lézine, A.-M., Maley, J., Marret, F., Vincens, A., 2010b. Millennial-scale changes in vegetation records from tropical Africa and South America during the last glacial. Quaternary Science Reviews 29, 2882-2899.

Hessler, I., Harrison, S.P., Kucera, M., Waelbroeck, C., Chen, M.T., Anderson, C., de Vernal, A., Fréchette, B., Cloke-Hayes, A., Leduc, G., Londeix, L., 2014. Implication of methodological uncertainties for mid-Holocene sea surface temperature reconstructions. Clim. Past 10, 2237-2252.

Heusser, C.J., 1995. Three Late Quaternary pollen diagrams from Southern Patagonia and their palaeoecological implications. Palaeogeography, Palaeoclimatology, Palaeoecology $118,1-24$.

Heusser, L., 1998. 14 - Spores and pollen in the marine realm, in: Haq, B.U., Boersma, A. (Eds.), Introduction to Marine Micropaleontology (Second Edition). Elsevier Science B.V., Amsterdam, pp. 327-339.

Heusser, L.E., 1983. Pollen distribution in the bottom sediments of the western North Atlantic Ocean. Marine Micropaleontology 8, 77-88.

Heusser, L.E., Balsam, W.L., 1977. Pollen distribution in the N.E. Pacific ocean. Quaternary Research 7, 45-62.

Heusser, L.E., Shackleton, N.J., 1979. Direct Marine-Continental Correlation: 150,000-Year Oxygen Isotope-Pollen Record from the North Pacific. Science 204, 837-839.

Hockaday, W.C., Grannas, A.M., Kim, S., Hatcher, P.G., 2006. Direct molecular evidence for the degradation and mobility of black carbon in soils from ultrahigh-resolution mass spectral analysis of dissolved organic matter from a fire-impacted forest soil. Organic Geochemistry 37, 501-510.

Hoogakker, B.A.A., Smith, R.S., Singarayer, J.S., Marchant, R., Prentice, I.C., Allen, J.R.M., Anderson, R.S., Bhagwat, S.A., Behling, H., Borisova, O., Bush, M., Correa-Metrio, A., De Vernal, A., Finch, J.M., Fréchette, B., Lozano-Garcia, S., Gosling, W.D., Granoszewski, W., Grimm, E.C., Grüger, E., Hanselman, J., Harrison, S.P., Hill, T.R., Huntley, B., JiménezMoreno, G., Kershaw, P., Ledru, M.P., Magri, D., McKenzie, M., Müller, U., Nakagawa, T., Novenko, E., Penny, D., Sadori, L., Scott, L., Stevenson, J., Valdes, P.J., Vandergoes, M., Velichko, A., Whitlock, C., Tzedakis, C., 2016. Terrestrial biosphere changes over the last 120 kyr. Climate of the Past 12, 51-73.

Hooghiemstra, H., 1989. Quaternary and Upper-Pliocene glaciations and forest development in the tropical Andes: evidence from a long high-resolution pollen record from the sedimentary basin of Bogota, Colombia. Palaeogeography, Palaeoclimatology, Palaeoecology 72, 11-26.

Hooghiemstra, H., Berrio, J.C., 2013. POLLEN RECORDS, LATE PLEISTOCENE | South America, in: Elias, S.A., Mock, C.J. (Eds.), Encyclopedia of Quaternary Science (Second Edition). Elsevier, Amsterdam, pp. 52-62.

Hooghiemstra, H., Lézine, A.-M., Leroy, S.A.G., Dupont, L., Marret, F., 2006. Late Quaternary palynology in marine sediments: A synthesis of the understanding of pollen distribution patterns in the NW African setting. Quaternary International 148, 29-44. 
Hooghiemstra, H., Sarmiento, G., 2001. Long continental pollen record from a tropical intermontane basin: Late Pliocene and Pleistocene history from a 540-meter core. Episodes 14, 107-115.

Hooghiemstra, H., Stalling, H., Agwu, C.O.C., Dupont, L.M., 1992. Vegetational and climatic changes at the northern fringe of the Sahara 250,000-5000 years BP: evidence from 4 marine pollen records located between Portugal and the Canary Islands. Review of Palaeobotany and Palynology 74, 1-53.

Hooghiemstra, H., van Geel, B., 1998. World list of Quaternary pollen and spore atlases. Review of Palaeobotany and Palynology 104, 157-182.

Hubau, W., Van den Bulcke, J., Van Acker, J., Beeckman, H., 2015. Charcoal-inferred Holocene fire and vegetation history linked to drought periods in the Democratic Republic of Congo. Global Change Biology 21, 2296-2308.

Huntley, B., Birks, H.J.B., 1983. An Atlas of Past and Present Pollenmaps for Europe: 013.000 B.P. years ago. Cambridge University Press, Cambridge.

Huntley, B., Prentice, I.C., 1988. July Temperatures in Europe from Pollen Data, 6000 Years Before Present. Science 241, 687-690.

Huntley, B., Webb, T., 1989. Migration: Species' Response to Climatic Variations Caused by Changes in the Earth's Orbit. Journal of Biogeography 16, 5-19.

Imbrie, J., Boyle, E.A., Clemens, S.C., Duffy, A., Howard, W.R., Kukla, G., Kutzbach, J., Martinson, D.G., Mclntyre, A., Mix, A.C., Molfino, B., Morley, J.J., Peterson, L.C., Pisias, N.G., Prell, W.L., Raymo, M.E., Shackleton, N.J., Toggweiler, J.R., 1992. On the Structure and Origin of Major Glaciation Cycles 1. Linear Responses to Milankovitch Forcing.

Paleoceanography $7,701-738$.

Inoue, J., Okuyama, C., Takemura, K., 2018. Long-term fire activity under the East Asian monsoon responding to spring insolation, vegetation type, global climate, and human impact inferred from charcoal records in Lake Biwa sediments in central Japan. Quaternary Science Reviews 179, 59-68.

IPCC, 2001. Climate Change 2001: The Scientific Basis. Contribution of Working Group I to the Third Assessment Report of the

Intergovernmental Panel on Climate Change, United Kingdom and New York, NY, USA ed. Cambridge University Press, Cambridge.

Iversen, J., 1944. Viscum, Hedera and Ilex as Climate Indicators. Geologiska Föreningen i Stockholm Förhandlingar 66, 463-483.

Ivory, S.J., Blome, M.W., King, J.W., McGlue, M.M., Cole, J.E., Cohen, A.S., 2016.

Environmental change explains cichlid adaptive radiation at Lake Malawi over the past 1.2 million years. Proceedings of the National Academy of Sciences 113, 11895-11900.

Ivory, S.J., Lézine, A.M., Vincens, A., Cohen, A.S., 2018. Waxing and waning of forests: Late Quaternary biogeography of southeast Africa. Global Change Biology 24, 2939-2951.

Jackson, S.T., Booth, R.K., 2007. PLANT MACROFOSSIL METHODS AND STUDIES |

Validation of Pollen Studies, in: Elias, S.A. (Ed.), Encyclopedia of Quaternary Science.

Elsevier, Oxford, pp. 2413-2422.

Jackson, S.T., Overpeck, J.T., 2000. Responses of plant populations and communities to environmental changes of the late Quaternary. Paleobiology 26, 194-220.

Jimenez-Moreno, G., Anderson, R.S., Desprat, S., Grigg, L.D., Grimm, E.C., Heusser, L.E., Jacobs, B.F., López-Martínez, C., Whitlock, C.L., Willard, D.A., 2010. Millennial-scale variability during the last glacial in vegetation records from North America. Quaternary Science Reviews 29, 2865-2881.

Johnsen, S.J., Clausen, H.B., Dansgaard, W., Fuhrer, K., Gundestrup, N., Hammer, C.U., Iversen, P., Jouzel, J., Stauffer, B., Steffensen, J.P., 1992. Irregular glacial interstadials in a new Greenland ice core. Nature 359, 311-313.

Jones, S.E., Pearce, K.G., 2014. A pollen morphology study from the Kelabit Highlands of Sarawak, Malaysian Borneo. Palynology 39, 150-204.

Jones, T.P., Chaloner, W.G., Kuhlbusch, T.A.J., 1997. Proposed Bio-geological and

Chemical Based Terminology for Fire-altered Plant Matter, in: J. S. Clark, H. Cachier, J. G. 
Goldammer, Stocks, B. (Eds.), Sediment Records of Biomass Burning and Global Change. Springer-Verlag Berlin Heidelberg, pp. 9-22.

Jouanneau, J.M., Garcia, C., Oliveira, A., Rodrigues, A., Dias, J.A., Weber, O., 1998. Dispersal and deposition of suspended sediment on the shelf off the Tagus and Sado estuaries S. W. Portugal. Progress in Oceanography 42, 233-257.

Jouzel, J., Masson-Delmotte, V., Cattani, O., Dreyfus, G., Falourd, S., Hoffmann, G., Minster, B., Nouet, J., Barnola, J.M., Chappellaz, J., Fischer, H., Gallet, J.C., Johnsen, S.,

Leuenberger, M., Loulergue, L., Luethi, D., Oerter, H., Parrenin, F., Raisbeck, G., Raynaud, D., Schilt, A., Schwander, J., Selmo, E., Souchez, R., Spahni, R., Stauffer, B., Steffensen, J.P., Stenni, B., Stocker, T.F., Tison, J.L., Werner, M., Wolff, E.W., 2007. Orbital and Millennial Antarctic Climate Variability over the Past 800,000 Years. Science 317 793-796. Julier, A.C.M., Jardine, P.E., Coe, A.L., Gosling, W.D., Lomax, B.H., Fraser, W.T., 2016. Chemotaxonomy as a tool for interpreting the cryptic diversity of Poaceae pollen. Review of Palaeobotany and Palynology 235, 140-147.

Kailas, J.G., Naik, M.C., Bheemalingappa, M., Ramakrishna, H., Rao, B.R.P., 2016. Arboreal diversity of the Andaman Islands, India, based on pollen analysis. Palynology 41, 370-388. Kapp's, R.O., 2000. Pollen and spores. The American Association of Stratigraphic Palynologists Foundation, College Station, Texas.

Kaufman, D.S., Ager, T.A., Anderson, N.J., Anderson, P.M., Andrews, J.T., Bartlein, P.J., Brubaker, L.B., Coats, L.L., Cwynar, L.C., Duvall, M.L., Dyke, A.S., Edwards, M.E., Eisner, W.R., Gajewski, K., Geirsdóttir, A., Hu, F.S., Jennings, A.E., Kaplan, M.R., Kerwin, M.W., Lozhkin, A.V., MacDonald, G.M., Miller, G.H., Mock, C.J., Oswald, W.W., Otto-Bliesner, B.L., Porinchu, D.F., Rühland, K., Smol, J.P., Steig, E.J., Wolfe, B.B., 2004. Holocene thermal maximum in the western Arctic $\left(0-180^{\circ} \mathrm{W}\right)$. Quaternary Science Reviews 23, 529-560. Kelly, E., 1990. Method for extracting opal phytoliths from soil and plant material. Intern. Rep., Dep. Agron, Colorado State Univ., Fort Collins.

Kershaw, P., van der Kaars, S., 2013. POLLEN RECORDS, LATE PLEISTOCENE | Australasia, in: Elias, S.A., Mock, C.J. (Eds.), Encyclopedia of Quaternary Science (Second Edition). Elsevier, Amsterdam, pp. 18-26.

Kilian, R., Lamy, F., 2012. A review of Glacial and Holocene paleoclimate records from southernmost Patagonia (49-55S). Quaternary Science Reviews 53, 1-23.

Kneller, M., Peteet, D., 1999. Late-Glacial to Early Holocene Climate Changes from a Central Appalachian Pollen and Macrofossil Record. Quaternary Research 51, 133-147.

Kondo, R., Childs, C., Atkinson, I., 1994. Opal Phytoliths of New Zealand. Manaaki Whenua Press, Lincoln, New Zealand.

Kuosmanen, N., Marquer, L., Tallavaara, M., Molinari, C., Zhang, Y., Alenius, T., Edinborough, K., Pesonen, P., Reitalu, T., Renssen, H., Trondman, A.-K., Seppä, H., 2018. The role of climate, forest fires and human population size in Holocene vegetation dynamics in Fennoscandia. Journal of Vegetation Science 29, 382-392.

Lamy, F., Kilian, R., Arz, H.W., Francois, J.-P., Kaiser, J., Prange, M., Steinke, T., 2010. Holocene changes in the position and intensity of the southern westerly wind belt. Nature Geoscience 3, 695.

Landais, A., Barnola, J.M., Masson-Delmotte, V., Jouzel, J., Chappellaz, J., Caillon, N., Huber, C., Leuenberger, M., Johnsen, S., 2004. A continuous record of temperature evolution over a whole sequence of Dansgaard-Oeschger during Marine Isotopic Stage 4 (76 to 62 kyr BP). Geophysical Research Letters 31 (L22211), 101-113.

Laskar, J., Robutel, P., Joutel, F., tineau, M.G., Correia, A.C.M., Levrard, B., 2004. A longterm numerical solution for the insolation quantities of the Earth. A\&A 428, 261-285.

Lavorel, S., Flannigan, M.D., Lambin, E.F., Scholes, M.C., 2007. Vulnerability of land systems to fire: Interactions among humans, climate, the atmosphere, and ecosystems. Mitigation and Adaptation Strategies for Global Change 12, 33-53.

Lawson, I.T., Tzedakis, P.C., Roucoux, K.H., Galanidou, N., 2013. The anthropogenic influence on wildfire regimes: charcoal records from the Holocene and Last Interglacial at Ioannina, Greece. Journal of Biogeography 40, 2324-2334. 
Leal, A., Berrío, J.C., Raimúndez, E., Bilbao, B., 2011. A pollen atlas of premontane woody and herbaceous communities from the upland savannas of Guayana, Venezuela. Palynology 35, 226-266.

Ledru, M.-P., Ceccantini, G., Gouveia, S.E.M., López-Sáez, J.A., Pessenda, L.C.R., Ribeiro, A.S., 2006. Millenial-scale climatic and vegetation changes in a northern Cerrado (northeast, Brazil) since the Last Glacial Maximum. Quaternary Science Reviews 25, 1110-1126. Ledru, M.P., Reimold, W.U., Ariztegui, D., Bard, E., Crósta, A.P., Riccomini, C., Sawakuchi, A.O., 2015. Why deep drilling in the Colônia Basin (Brazil)? Scientific Drilling 20, 33-39. Lentfer, C.J., Boyd, W.E., 1998. A Comparison of Three Methods for the Extraction of Phytoliths from Sediments. Journal of Archaeological Science 25, 1159-1183.

Levavasseur, G., Vrac, M., Roche, D.M., Paillard, D., 2012. Statistical modelling of a new global potential vegetation distribution. Environmental Research Letters 7, 044019.

Leys, B., Carcaillet, C., Dezileau, L., Ali, A.A., Bradshaw, R.H.W., 2013. A comparison of charcoal measurements for reconstruction of Mediterranean paleo-fire frequency in the mountains of Corsica. Quaternary Research 79, 337-349.

Lézine, A.-M., Holl, A.F.C., Lebamba, J., Vincens, A., Assi-Khaudjis, C., Février, L., Sultan, É., 2013. Temporal relationship between Holocene human occupation and vegetation change along the northwestern margin of the Central African rainforest. Comptes Rendus Geoscience 345, 327-335.

Lézine, A.-M., Vergnaud-Grazzini, C., 1993. Evidence of forest extension in west Africa since 22,000 BP: A pollen record from the eastern tropical Atlantic. Quaternary Science Reviews 12, 203-210.

Lindbladh, M., O'Connor, R., Jacobson Jr, G.L., 2002. Morphometric analysis of pollen grains for paleoecological studies: Classification of Picea from eastern North America. American Journal of Botany 89, 1459-1467.

Lisiecki, L.E., Raymo, M.E., 2005. A Pliocene-Pleistocene stack of 57 globally distributed benthic d180 records. Paleoceanography 20, PA1003, doi:1010.1029/2004PA001071.

Lorente, F.L., Buso Junior, A.A., de Oliveira, P.E., Pessenda, L.C.R., 2017. Atlas palinológico. Laboratório C-14 CENA-USP/PALYNOLOGICAL ATLAS.

Loulergue, L., Schilt, A., Spahni, R., Masson-Delmotte, V., Blunier, T., Lemieux, B., Barnola, J.-M., Raynaud, D., Stocker, T.F., Chappellaz, J., 2008. Orbital and millennial-scale features of atmospheric $\mathrm{CH} 4$ over the past 800,000[thinsp]years. Nature 453, 383-386.

Lozhkin, A.V., Anderson, P.M., 2013. POLLEN RECORDS, LATE PLEISTOCENE I Northern Asia, in: Elias, S.A., Mock, C.J. (Eds.), Encyclopedia of Quaternary Science (Second Edition). Elsevier, Amsterdam, pp. 27-38.

Madella, M., Icpn Working, G., Alexandre, A., Icpn Working, G., Ball, T., Icpn Working, G., 2005. International Code for Phytolith Nomenclature 1.0. Annals of Botany 96, 253-260.

Madella, M., Powers-Jones, A.H., Jones, M.K., 1998. A Simple Method of Extraction of Opal Phytoliths from Sediments Using a Non-Toxic Heavy Liquid. Journal of Archaeological Science 25, 801-803.

Maezumi, S.Y., Robinson, M., de Souza, J., Urrego, D.H., Schaan, D., Alves, D., Iriarte, J., 2018. New Insights From Pre-Columbian Land Use and Fire Management in Amazonian Dark Earth Forests. Frontiers in Ecology and Evolution 6.

Maher, L.J., 1981. Statistics for microfossil concentration measurements employing samples spiked with marker grains. Review of Palaeobotany and Palynology 32, 153-191.

Maley, J., 1991. The African rain forest vegetation and palaeoenvironments during late quaternary. Climatic Change 19, 79-98.

Maley, J., 2002. A catastrophic destruction of African forests about 2,500 years ago still exerts a major influence on present vegetation formations. IDS bulletin 33, 13-30.

Maley, J., Doumenge, C., Giresse, P., Mahe, G., Philippon, N., Hubau, W., O. Lokonda, M., M. Tshibamba, J., Chepstow-lusty, A., 2018. Late Holocene forest contraction and fragmentation in central Africa. Quaternary Research 89, 43-59.

Maley, J., Giresse, P., Doumenge, C., Favier, C., 2012. Comment on "Intensifying Weathering and Land Use in Iron Age Central Africa". Science, 2012: 337 (6098): 1040 DOI: 10.1126/science. 1221820 . 
Maley, J., Willis, K., 2010. Un couloir savanicole a-t-il recoupé les forêts d'Afrique centrale il y a 2500 ans ? Lettre CoForChange, $n^{\circ} 2$. European Program www.coforchange.eu.

Marcott, S.A., Shakun, J.D., Clark, P.U., Mix, A.C., 2013. A Reconstruction of Regional and Global Temperature for the Past 11,300 Years. Science 339, 1198-1201.

Marinova, E., Harrison, S.P., Bragg, F., Connor, S., Laet, V., Leroy, S.A.G., Mudie, P., Atanassova, J., Bozilova, E., Caner, H., Cordova, C., Djamali, M., Filipova-Marinova, M., Gerasimenko, N., Jahns, S., Kouli, K., Kotthoff, U., Kvavadze, E., Lazarova, M., Novenko, E., Ramezani, E., Röpke, A., Shumilovskikh, L., Tanţău, I., Tonkov, S., 2018. Pollen-derived biomes in the Eastern Mediterranean-Black Sea-Caspian-Corridor. Journal of Biogeography 45, 484-499.

Markgraf, V., Huber, U.M., 2010. Late and postglacial vegetation and fire history in Southern Patagonia and Tierra del Fuego. Palaeogeography, Palaeoclimatology, Palaeoecology 297, 351-366.

Marlon, J.R., Bartlein, P.J., Carcaillet, C., Gavin, D.G., Harrison, S.P., Higuera, P.E., Joos, F., Power, M.J., Prentice, I.C., 2008. Climate and human influences on global biomass burning over the past two millennia. Nature Geoscience 1, 697-702.

Marlon, J.R., Bartlein, P.J., Daniau, A.-L., Harrison, S.P., Maezumi, S.Y., Power, M.J., Tinner, W., Vanniére, B., 2013. Global biomass burning: a synthesis and review of Holocene paleofire records and their controls. Quaternary Science Reviews 65, 5-25.

Marlon, J.R., Bartlein, P.J., Walsh, M.K., Harrison, S.P., Brown, K.J., Edwards, M.E., Higuera, P.E., Power, M.J., Anderson, R.S., Briles, C., Brunelle, A., Carcaillet, C., Daniels, M., Hu, F.S., Lavoie, M., Long, C., Minckley, T., Richard, P.J.H., Scott, A.C., Shafer, D.S., Tinner, W., Umbanhowar Jr., C.E., Whitlock, C., 2009. Wildfire responses to abrupt climate change in North America. Proceedings of the National Academy of Sciences 106, 2519-2524 Marlon, J.R., Kelly, R., Daniau, A.L., Vannière, B., Power, M.J., Bartlein, P., Higuera, P., Blarquez, O., Brewer, S., Brücher, T., Feurdean, A., Romera, G.G., Iglesias, V., Maezumi, S.Y., Magi, B., Courtney Mustaphi, C.J., Zhihai, T., 2016. Reconstructions of biomass burning from sediment-charcoal records to improve data-model comparisons.

Biogeosciences 13, 3225-3244.

Marlon, J.R., Pederson, N., Nolan, C., Goring, S., Shuman, B., Robertson, A., Booth, R., Bartlein, P.J., Berke, M.A., Clifford, M., Cook, E., Dieffenbacher-Krall, A., Dietze, M.C., Hessl, A., Bradford Hubeny, J., Jackson, S.T., Marsicek, J., McLachlan, J., Mock, C.J., Moore, D.J.P., Nichols, J., Peteet, D., Schaefer, K., Trouet, V., Umbanhowar, C., Williams, J.W., Yu, Z., 2017. Climatic history of the northeastern United States during the past 3000 years. Climate of the Past 13, 1355-1379.

Marquer, L., Dallmeyer, A., Poska, A., Pongratz, J., Smith, B., Gaillard, M.-J., 2018. Modelling past human-induced vegetation change is a challenge - the case of Europe. Past Global Changes Magazine 26, 12-13.

Marquer, L., Gaillard, M.-J., Sugita, S., Poska, A., Trondman, A.-K., Mazier, F., Nielsen, A.B., Fyfe, R.M., Jönsson, A.M., Smith, B., Kaplan, J.O., Alenius, T., Birks, H.J.B., Bjune, A.E., Christiansen, J., Dodson, J., Edwards, K.J., Giesecke, T., Herzschuh, U., Kangur, M., Koff, T., Latałowa, M., Lechterbeck, J., Olofsson, J., Seppä, H., 2017. Quantifying the effects of land use and climate on Holocene vegetation in Europe. Quaternary Science Reviews 171, 20-37.

Marquer, L., Gaillard, M.-J., Sugita, S., Trondman, A.-K., Mazier, F., Nielsen, A.B., Fyfe, R.M., Odgaard, B.V., Alenius, T., Birks, H.J.B., Bjune, A.E., Christiansen, J., Dodson, J., Edwards, K.J., Giesecke, T., Herzschuh, U., Kangur, M., Lorenz, S., Poska, A., Schult, M., Seppä, H., 2014. Holocene changes in vegetation composition in northern Europe: why quantitative pollen-based vegetation reconstructions matter. Quaternary Science Reviews 90, 199-216.

Marsicek, J., Shuman, B.N., Bartlein, P.J., Shafer, S.L., Brewer, S., 2018. Reconciling divergent trends and millennial variations in Holocene temperatures. Nature 554, 92.

Martin, A.C., Harvey, W.J., 2017. The Global Pollen Project: a new tool for pollen identification and the dissemination of physical reference collections. Methods in Ecology and Evolution 8, 892-897. 
Martrat, B., Grimalt, J.O., Shackleton, N.J., de Abreu, L., Hutterli, M.A., Stocker, T.F., 2007. Four climate cycles of recurring deep and surface water destabilizations on the Iberian margin. Science 317, 502-507, doi: 510.1126/science.1139994.

Masson-Delmotte, V., Stenni, B., Pol, K., Braconnot, P., Cattani, O., Falourd, S., Kageyama, M., Jouzel, J., Landais, A., Minster, B., Barnola, J.M., Chappellaz, J., Krinner, G., Johnsen, S., Röthlisberger, R., Hansen, J., Mikolajewicz, U., Otto-Bliesner, B., 2010. EPICA Dome C record of glacial and interglacial intensities. Quaternary Science Reviews 29, 113-128. Mauri, A., Davis, B.A.S., Collins, P.M., Kaplan, J.O., 2014. The influence of atmospheric circulation on the mid-Holocene climate of Europe: a data-model comparison. Clim. Past 10, 1925-1938.

Mauri, A., Davis, B.A.S., Collins, P.M., Kaplan, J.O., 2015. The climate of Europe during the Holocene: a gridded pollen-based reconstruction and its multi-proxy evaluation. Quaternary Science Reviews 112, 109-127.

Mayle, F.E., Burbridge, R., Killeen, T.J., 2000. Millennial-Scale Dynamics of Southern Amazonian Rain Forests. Science 290, 2291-2294.

Mazier, F., Broström, A., Bragée, P., Fredh, D., Stenberg, L., Thiere, G., Sugita, S., Hammarlund, D., 2015. Two hundred years of land-use change in the South Swedish Uplands: comparison of historical map-based estimates with a pollen-based reconstruction using the landscape reconstruction algorithm. Vegetation History and Archaeobotany 24, 555-570.

McAndrew, J.H., King, J.E., 1976. Pollen of the North American Quaternary: The top twenty. Geoscience and Man 15, 41-49.

McManus, J.F., Oppo, D.W., Cullen, J.L., 1999. A 0.5-million-year record of millennial-scale climate variability in the North Atlantic. Science 283, 971-975.

Meadows, M.E., Chase, B.M., 2013. POLLEN RECORDS, LATE PLEISTOCENE | Africa, in: Elias, S.A., Mock, C.J. (Eds.), Encyclopedia of Quaternary Science (Second Edition).

Elsevier, Amsterdam, pp. 9-17.

Melles, M., Brigham-Grette, J., Minyuk, P.S., Nowaczyk, N.R., Wennrich, V., DeConto, R.M., Anderson, P.M., Andreev, A.A., Coletti, A., Cook, T.L., Haltia-Hovi, E., Kukkonen, M., Lozhkin, A.V., Rosén, P., Tarasov, P., Vogel, H., Wagner, B., 2012. 2.8 Million Years of Arctic Climate Change from Lake El'gygytgyn, NE Russia. Science 337, 315-320.

Meltsov, V., Poska, A., Saar, M., 2008. Pollen size in Carex: The effect of different chemical treatments and mounting media. GRANA 47, 220-233.

Mensing, S.A., Michaelsen, J., Byrne, R., 1999. A 560-Year Record of Santa Ana Fires Reconstructed from Charcoal Deposited in the Santa Barbara Basin, California. Quaternary Research 51, 295-305.

Mercader, J., Bennett, T., Esselmont, C., Simpson, S., Walde, D., 2009. Phytoliths in woody plants from the Miombo woodlands of Mozambique. Annals of Botany 104, 91-113.

Mercader, J., Runge, F., Vrydaghs, L., Doutrelepont, H., Ewango, C.E.N., Juan-Tresseras, J., 2000. Phytoliths from Archaeological Sites in the Tropical Forest of Ituri, Democratic Republic of Congo. Quaternary Research 54, 102-112.

Milankovitch, M.M., 1941. Kanon der Erdbestrahlung. Köninglich Serbische Akademie, Beograd.

Miller, C.S., Gosling, W.D., 2014. Quaternary forest associations in lowland tropical West Africa. Quaternary Science Reviews 84, 7-25.

Miller, C.S., Gosling, W.D., Kemp, D.B., Coe, A.L., Gilmour, I., 2016. Drivers of ecosystem and climate change in tropical West Africa over the past 540 000 years. Journal of Quaternary Science 31, 671-677.

Monnin, E., Indermühle, A., Dällenbach, A., Flückiger, J., Stauffer, B., Stocker, T.F., Raynaud, D., Barnola, J.-M., 2001. Atmospheric $\mathrm{CO}<$ sub $>2</$ sub $>$ Concentrations over the Last Glacial Termination. Science 291, 112-114.

Montade, V., 2011. Vegetation and climate of chilean Patagonia during the last 20, 000 years from marine pollen data. Université Paris Sud - Paris XI. 
Montade, V., Kagayema, M., Combourieu Nebout, N., Ledru, M.-P., Michel, E., Siani, G., C., K., 2015. Teleconnection between the intertropical convergence zone and southern westerly winds throughout the last deglaciation. Geology 43, 735-738.

Montade, V., Nebout, N.C., Chapron, E., Mulsow, S., Abarzúa, A.M., Debret, M., Foucher, A., Desmet, M., Winiarski, T., Kissel, C., 2012. Regional vegetation and climate changes during the last 13kyr from a marine pollen record in Seno Reloncaví, southern Chile. Review of Palaeobotany and Palynology 181, 11-21.

Montade, V., Schüler, L., Hemp, A., Bremond, L., Salamanca Duarte, A.M., Behling, H., 2018. Late Quaternary ecotone change between sub-alpine and montane forest zone on the leeward northern slope of Mt. Kilimanjaro. Journal of Vegetation Science 29, 459-468. Mooney, S.D., Harrison, S.P., Bartlein, P.J., Daniau, A.-L., Stevenson, J., Brownlie, K.C., Buckman, S., Cupper, M., Luly, J., Black, M., Colhoun, E., D'Costa, D., Dodson, J., Haberle, S., Hope, G.S., Kershaw, P., Kenyon, C., McKenzie, M., Williams, N., 2011. Late Quaternary fire regimes of Australasia. Quaternary Science Reviews 30, 28-46.

Moore, P.D., Webb, J.A., Collinson, M.E., 1991. Pollen analysis, $2^{\circ}$ édition ed. Blackwell scientific publication, Oxford.

Morales-Molino, C., Colombaroli, D., Valbuena-Carabaña, M., Tinner, W., Salomón, R.L., Carrión, J.S., Gil, L., 2017a. Land-use history as a major driver for long-term forest dynamics in the Sierra de Guadarrama National Park (central Spain) during the last millennia:

implications for forest conservation and management. Global and Planetary Change 152, 6475.

Morales-Molino, C., García Antón, M., Morla, C., 2011. Late Holocene vegetation dynamics on an Atlantic-Mediterranean mountain in NW Iberia. Palaeogeography, Palaeoclimatology, Palaeoecology 302, 323-337.

Morales-Molino, C., Tinner, W., García-Antón, M., Colombaroli, D., 2017b. The historical demise of Pinus nigra forests in the Northern Iberian Plateau (south-western Europe). Journal of Ecology 105, 634-646.

Moreno, A., Cacho, I., Canals, M., Prins, M.A., Sánchez-Goñi, M., x, a, F., Grimalt, J.O., Weltje, G.J., 2002. Saharan Dust Transport and High-Latitude Glacial Climatic Variability: The Alboran Sea Record. Quaternary Research 58, 318-328.

Moreno, P.I., 2004. Millennial-scale climate variability in northwest Patagonia over the last 15000 yr. Journal of Quaternary Science 19, 35-47.

Moreno, P.I., Francois, J.P., Moy, C.M., Villa-Martínez, R., 2010. Covariability of the Southern Westerlies and atmospheric CO2 during the Holocene. Geology 38, 727-730. Moreno, P.I., Lowell, T.V., Jacobson, G.L., Denton, G.H., 1999. Abrupt Vegetation and Climate Changes during the Last Glacial Maximum and Last Termination in the Chilean Lake District: A Case Study from Canal de la Puntilla (41\&\#xb0;S). Geografiska Annaler. Series A, Physical Geography 81, 285-311.

Moreno, P.I., Videla, J., 2016. Centennial and millennial-scale hydroclimate changes in northwestern Patagonia since 16,000 yr BP. Quaternary Science Reviews 149, 326-337. Morin-Rivat, J., Biwolé, A., Gorel, A.-P., Vleminckx, J., Gillet, J.-F., Bourland, N., Hardy, O.J., Smith, A.L., Daïnou, K., Dedry, L., Beeckman, H., Doucet, J.-L., 2016. High spatial resolution of late-Holocene human activities in the moist forests of central Africa using soil charcoal and charred botanical remains. The Holocene 26, 1954-1967.

Mourguiart, P., Ledru, M.P., 2003. Last Glacial Maximum in an Andean cloud forest environment (Eastern Cordillera, Bolivia). Geology 31, 195-198.

Mudavath, C.N., Ganga Kailas, J., Sugali, S., Ravula, D., Hari, R., Boyina, R.P.R., 2017. The non-arboreal diversity of the Andaman Islands, India, based on pollen analysis. Palynology 41, 441-461.

Mudie, P.J., McCarthy, F.M.G., 2006. Marine palynology: potentials for onshore-offshore correlation of Pleistocene-Holocene records. Transactions of the Royal Society of South Africa 61, 139-157.

Mulholland, S.C., 1989. Phytolith shape frequencies in North Dakota grasses: a comparison to general patterns. Journal of Archaeological Science 16, 489-511. 
Mulholland, S.C., Rapp, J.G., 1992. A morphological classification of grass silica-bodies, Phytoliths Systematics: Emerging Issues. Advances in Archaeological and Museum Science. Plenum Press, New York, pp. 65-89.

Müller, U.C., Pross, J., Tzedakis, P.C., Gamble, C., Kotthoff, U., Schmiedl, G., Wulf, S., Christanis, K., 2011. The role of climate in the spread of modern humans into Europe. Quaternary Science Reviews 30, 273-279.

Naughton, F., Keigwin, L., Peteet, D., Costas, S., Desprat, S., Oliveira, D., de Vernal, A., Voelker, A., Abrantes, F., 2015. A 12,000-yr pollen record off Cape Hatteras - Pollen sources and mechanisms of pollen dispersion. Marine Geology 367, 118-129.

Naughton, F., Sanchez Goñi, M.F., Desprat, S., Turon, J.L., Duprat, J., Malaizé, B., Joli, C., Cortijo, E., Drago, T., Freitas, M.C., 2007. Present-day and past (last 25000 years) marine pollen signal off western Iberia. Marine Micropaleontology 62, 91-114.

Naughton, F., Sánchez Goñi, M.F., Kageyama, M., Bard, E., Duprat, J., Cortijo, E., Desprat, S., Malaizé, B., Joly, C., Rostek, F., Turon, J.L., 2009. Wet to dry climatic trend in northwestern Iberia within Heinrich events. Earth and Planetary Science Letters 284, 329-342. Naughton, F., Sanchez Goñi, M.F., Rodrigues, T., Salgueiro, E., Costas, S., Desprat, S., Duprat, J., Michel, E., Rossignol, L., Zaragosi, S., Voelker, A.H.L., Abrantes, F., 2016. Climate variability across the last deglaciation in NW Iberia and its margin. Quaternary International 414, 9-22.

Nelson, D.M., Verschuren, D., Urban, M.A., Hu, F.S., 2012. Long-term variability and rainfall control of savanna fire regimes in equatorial East Africa. Global Change Biology 18, 31603170.

Neumann, K., Bostoen, K., Höhn, A., Kahlheber, S., Ngomanda, A., Tchiengué, B., 2012a. First farmers in the Central African rainforest: A view from southern Cameroon. Quaternary International 249, 53-62.

Neumann, K., Eggert, M.K.H., Oslisly, R., Clist, B., Denham, T., de Maret, P., Ozainne, S., Hildebrand, E., Bostoen, K., Salzmann, U., Schwartz, D., Eichhorn, B., Tchiengué, B., Höhn, A., 2012b. Comment on "Intensifying Weathering and Land Use in Iron Age Central Africa". Science 337, 1040-1040.

Neumann, K., Fahmy, A., Lespez, L., Ballouche, A., Huysecom, E., 2009. The Early Holocene palaeoenvironment of Ounjougou (Mali): Phytoliths in a multiproxy context. Palaeogeography, Palaeoclimatology, Palaeoecology 276, 87-106.

Neylon, C., 2017. Building a Culture of Data Sharing: Policy Design and Implementation for Research Data Management in Development Research. Research Ideas and Outcomes 3, e21773.

Ngomanda, A., Chepstow-Lusty, A., Makaya, M., Schevin, P., Maley, J., Fontugne, M., Oslisly, R., Rabenkogo, N., Jolly, D., 2005. Vegetation changes during the past 1300 years in western equatorial Afnrca: a highresolution pollen record from Lake Kamalee, Lope Reserve, Central Gabon. The Holocene 15, 1021-1031.

Nichols, G.J., Cripps, J.A., Collinson, M.E., Scott, A.C., 2000. Experiments in waterlogging and sedimentology of charcoal: results and implications. Palaeogeography,

Palaeoclimatology, Palaeoecology 164, 43-56.

Nielsen, A.B., Giesecke, T., Theuerkauf, M., Feeser, I., Behre, K.-E., Beug, H.-J., Chen, S.H., Christiansen, J., Dörfler, W., Endtmann, E., Jahns, S., de Klerk, P., Kühl, N., Latałowa, M., Odgaard, B.V., Rasmussen, P., Stockholm, J.R., Voigt, R., Wiethold, J., Wolters, S., 2012. Quantitative reconstructions of changes in regional openness in north-central Europe reveal new insights into old questions. Quaternary Science Reviews 47, 131-149.

Nielsen, A.B., Odgaard, B.V., 2010. Quantitative landscape dynamics in Denmark through the last three millennia based on the Landscape Reconstruction Algorithm approach.

Vegetation History and Archaeobotany 19, 375-387.

Noël, H., 2001. Caractérisation et calibration des flux organiques sédimentaires dérivant du bassin versant et de la production aquatique (Annecy, le Petit Lac) : rôles respectifs de l'Homme et du climat sur l'évolution des flux organiques au cours des 6000 dernières années, p. 272 p. 
Novello, A., Barboni, D., Berti-Equille, L., Mazur, J.-C., Poilecot, P., Vignaud, P., 2012. Phytolith signal of aquatic plants and soils in Chad, Central Africa. Review of Palaeobotany and Palynology 178, 43-58.

Novello, A., Lebatard, A.-E., Moussa, A., Barboni, D., Sylvestre, F., Bourlès, D.L., Paillès, C., Buchet, G., Decarreau, A., Duringer, P., Ghienne, J.-F., Maley, J., Mazur, J.-C., Roquin, C., Schuster, M., Vignaud, P., 2015. Diatom, phytolith, and pollen records from a 10Be/9Be dated lacustrine succession in the Chad basin: Insight on the Miocene-Pliocene paleoenvironmental changes in Central Africa. Palaeogeography, Palaeoclimatology, Palaeoecology 430, 85-103.

Novello, A., Lebatard, A.E., Moussa, A., Barboni, D., Sylvestre, F., Bourlès, D.L., Paillès, C., Buchet, G., Decarreau, A., Duringer, P., Ghienne, J.F., Mazur, J.C., Roquin, C., Schuster, M., Vignaud, P., 2016. Phytolith records from a 10Be/9Be dated lacustrine succession in the Lake Chad basin: insight on the Pliocene palaeoenvironmental changes in Central Africa. Quaternary International 404, 177.

Okuda, M., Yasuda, Y., Setoguchi, T., 2001. Middle to Late Pleistocene vegetation history and climatic changes at Lake Kopais, Southeast Greece. Boreas 30, 73-82.

Olsson, F., Gaillard, M.-J., Lemdahl, G., Greisman, A., Lanos, P., Marguerie, D., Marcoux, N., Skoglund, P., Wäglind, J., 2010. A continuous record of fire covering the last 10,500 calendar years from southern Sweden - The role of climate and human activities.

Palaeogeography, Palaeoclimatology, Palaeoecology 291, 128-141.

Ortu, E., Brewer, S., Peyron, O., 2006. Pollen-inferred palaeoclimate reconstructions in mountain areas: problems and perspectives. Journal of Quaternary Science 21, 615-627. Otto-Bliesner, B.L., Braconnot, P., Harrison, S.P., Lunt, D.J., Abe-Ouchi, A., Albani, S., Bartlein, P.J., Capron, E., Carlson, A.E., Dutton, A., Fischer, H., Goelzer, H., Govin, A., Haywood, A., Joos, F., LeGrande, A.N., Lipscomb, W.H., Lohmann, G., Mahowald, N., Nehrbass-Ahles, C., Pausata, F.S.R., Peterschmitt, J.Y., Phipps, S.J., Renssen, H., Zhang, Q., 2017. The PMIP4 contribution to CMIP6 - Part 2: Two interglacials, scientific objective and experimental design for Holocene and Last Interglacial simulations. Geosci. Model Dev. 10, 3979-4003.

Overballe-Petersen, M.V., Nielsen, A.B., Bradshaw, R.H.W., 2013. Quantitative vegetation reconstruction from pollen analysis and historical inventory data around a Danish small forest hollow. Journal of Vegetation Science 24, 755-771.

Overpeck, J.T., Webb, R.S., Webb, I.I.I.T., 1992. Mapping eastern North American vegetation change of the past $18 \mathrm{ka}$ : No-analogs and the future. Geology 20, 1071-1074. Paduano, G.M., Bush, M.B., Baker, P.A., Fritz, S.C., Seltzer, G.O., 2003. A vegetation and fire history of Lake Titicaca since the Last Glacial Maximum. Palaeogeography,

Palaeoclimatology, Palaeoecology 194, 259-279.

Palmer, T.Y., Northcutt, L.I., 1975. Convection columns above large experimental fires. Fire Technology 11, 111-118.

Parmenter, C., Folger, D.W., 1974. Eolian Biogenic Detritus in Deep Sea Sediments: A Possible Index of Equatorial Ice Age Aridity. Science 185, 695-698.

Past Interglacials Working Group of PAGES, 2016. Interglacials of the last 800,000 years. Reviews of Geophysics 54, 162-219.

Patterson, W.A.I., Edwards, K.J., Maguire, D.J., 1987. Microscopic charcoal as a fossil indicator of fire. Quaternary Science Reviews 6, 3-23.

Pearsall, D.M., 2000. Paleoethnobotany: a Handbook of Procedures, second ed. ed. Academic Press, San Diego.

Peglar, S.M., 1993. The mid-Holocene Ulmus decline at Diss Mere, Norfolk, UK: a year-byyear pollen stratigraphy from annual laminations. The Holocene 3, 1-13.

Pèlachs, A., Julià, R., Pérez-Obiol, R., Soriano, J.M., Bal, M.-C., Cunill, R., Catalan, J., 2011. Potential influence of Bond events on mid-Holocene climate and vegetation in southern Pyrenees as assessed from Burg lake LOI and pollen records. The Holocene 21, 95-104. Pérez-Sanz, A., González-Sampériz, P., Moreno, A., Valero-Garcés, B., Gil-Romera, G., Rieradevall, M., Tarrats, P., Lasheras-Álvarez, L., Morellón, M., Belmonte, A., Sancho, C., Sevilla-Callejo, M., Navas, A., 2013. Holocene climate variability, vegetation dynamics and 
fire regime in the central Pyrenees: the Basa de la Mora sequence (NE Spain). Quaternary Science Reviews 73, 149-169.

Peteet, D., 1995. Global Younger Dryas? Quaternary International 28, 93-104.

Petit, J.R., Jouzel, J., Raynaud, D., Barkov, N.I., Barnola, J.M., Basile, I., Bender, M., Chappellaz, J., Davis, M., Delaygue, G., Delmotte, M., Kotlyakov, V.M., Legrand, M., Lipenkov, V.Y., Lorius, C., PÉpin, L., Ritz, C., Saltzman, E., Stievenard, M., 1999. Climate and atmospheric history of the past 420,000 years from the Vostok ice core, Antarctica. Nature 399, 429.

Peyron, O., Guiot, J., Cheddadi, R., Tarasov, P., Reille, M., de Beaulieu, J.-L., Bottema, S., Andrieu, V., 1998. Climatic Reconstrustion in Europe for 18,000 yr BP from Pollen Data. Quaternary Research 49, 183-196.

Pickarski, N., Kwiecien, O., Langgut, D., Litt, T., 2015. Abrupt climate and vegetation variability of eastern Anatolia during the last glacial. Clim. Past 11, 1491-1505.

Piperno, D.R., 2006. Phytoliths. A Comprehensive Guide for Archaeologists and Paleoecologists

Oxford: AltaMira Press, Lanham, New York, Toronto.

Piperno, D.R., Andres, T.C., Stothert, K.E., 2000. Phytoliths in Cucurbita and other Neotropical Cucurbitaceae and their Occurrence in Early Archaeological Sites from the Lowland American Tropics. Journal of Archaeological Science 27, 193-208.

Piperno, D.R., Pearsall, D.M., 1998. The silica bodies of tropical American grasses: Morphology, taxonomy, and implications for grass systematics and fossil phytolith identification. Smithsonian Contributions to Botany 85, 1-40.

Piperno, D.R., Ranere, A.J., Holst, I., Iriarte, J., Dickau, R., 2009. Starch grain and phytolith evidence for early ninth millennium B.P. maize from the Central Balsas River Valley, Mexico. Proceedings of the National Academy of Sciences 106, 5019-5024.

Pokras, E.M., Mix, A.C., 1985. Eolian evidence for spatial variability of late Quaternary climates in tropical Africa. Quaternary Research 24, 137-149.

Power, M.J., Bush, M.B., Behling, H., Horn, S., Mayle, F., Urrego, D.H., 2010a. Paleofire activity in tropical America during the last 21,000 years: A regional synthesis based on sedimentary charcoal. PAGES news 18, 73-75.

Power, M.J., Marlon, J., Ortiz, N., Bartlein, P.J., Harrison, S.P., Mayle, F.E., Ballouche, A., Bradshaw, R.H.W., Carcaillet, C., Cordova, C., Mooney, S., Moreno, P.I., Prentice, I.C., Thonicke, K., Tinner, W., Whitlock, C., Zhang, Y., Zhao, Y., Ali, A.A., Anderson, R.S., Beer, R., Behling, H., Briles, C., Brown, K.J., Brunelle, A., Bush, M., Camill, P., Chu, G.Q., Clark, J., Colombaroli, D., Connor, S., Daniau, A.-L., Daniels, M., Dodson, J., Doughty, E., Edwards, M.E., Finsinger, W., Foster, D., Frechette, J., Gaillard, M.-J., Gavin, D.G., Gobet, E., Haberle, S., Hallett, D.J., Higuera, P.E., Hope, G., Horn, S., Inoue, J., Kaltenreider, P., Kennedy, L., Kong, Z.C., Larsen, C., Long, C.J., Lynch, J.A., Lynch, E.A., McGlone, M., Meeks, S., Mensing, S., Meyer, G., Minckley, T., Mohr, J., Nelson, D.M., New, J., Newnham, R., Noti, R., Oswald, W., Pierce, J., Richard, P.J.H., Rowe, C., Sanchez Goñi, M.F., Shuman, B.J., Takahara, H., Toney, J., Turney, C., Urrego-Sanchez, D.H., Umbanhowar, C., Vandergoes, M., Vanniere, B., Vescovi, E., Walsh, M., Wang, X., Williams, N., Wilmshurst, J., Zhang, J.H., 2008. Changes in fire regimes since the Last Glacial Maximum: an assessment based on a global synthesis and analysis of charcoal data. Climate Dynamics 30, 887-907.

Power, M.J., Marlon, J.R., Bartlein, P.J., Harrison, S.P., 2010b. Fire History and the Global Charcoal Database: a new tool for hypothesis testing and data exploration.

Palaeogeography, Palaeoclimatology, Palaeoecology 291, 52-59.

Prado, L.F., Wainer, I., Chiessi, C.M., Ledru, M.P., Turcq, B., 2013. A mid-Holocene climate reconstruction for eastern South America. Clim. Past 9, 2117-2133.

Prat, H., 1932. L'epiderme des Graminees. Etude anatomique et systematique, Sciences naturelles. Faculté des sciences de Paris.

Prentice, C., 1988. Records of vegetation in time and space: the principles of pollen analysis, in: Huntley, B., Webb, T. (Eds.), Vegetation history. Springer Netherlands, Dordrecht, pp. 1742. 
Prentice, I.C., 1985. Pollen representation, source area, and basin size: toward a unified theory of pollen analysis. Quaternary Research 23, 76-86.

Prentice, I.C., Guiot, J., Huntley, B., Jolly, D., Cheddadi, R., 1996. Reconstructing biomes from palaeocological data: a general method and its application to European pollen data at 0 and $6 \mathrm{ka}$. Climate Dynamics 12, 185-194.

Prentice, I.C., Harrison, S.P., Jolly, D., Guiot, J., 1998. The climate and biomes of Europe at $6000 \mathrm{yr}$ BP: comparison of model simulations and pollen-based reconstructions. Quaternary Science Reviews 17, 659-668.

Prentice, I.C., Jolly, D., 2000. Mid-Holocene and glacial-maximum vegetation geography of the northern continents and Africa. Journal of Biogeography 27, 507-519.

Prentice, I.C., Parsons, R.W., 1983. Maximum Likelihood Linear Calibration of Pollen Spectra in Terms of Forest Composition. Biometrics 39, 1051-1057.

Prokopenko, A.A., Bezrukova, E.V., Khursevich, G.K., Solotchina, E.P., Kuzmin, M.I., Tarasov, P.E., 2010. Climate in continental interior Asia during the longest interglacial of the past 500000 years: The new MIS 11 records from Lake Baikal, SE Siberia. Climate of the Past 6, 31-48.

Prokopenko, A.A., Kuzmin, M.I., Li, H.C., Woo, K.S., Catto, N.R., 2009. Lake Hovsgol basin as a new study site for long continental paleoclimate records in continental interior Asia: General context and current status. Quaternary International 205, 1-11.

Pross, J., Kotthoff, U., Müller, U.C., Peyron, O., Dormoy, I., Schmiedl, G., Kalaitzidis, S., Smith, A.M., 2009. Massive perturbation in terrestrial ecosystems of the Eastern Mediterranean region associated with the $8.2 \mathrm{kyr}$ B.P. climatic event. Geology 37, 887-890. Punt, W., Hoen, P.P., Blackmore, S., Nilssont, S., Le Thomas, A., 2007. Glossary of pollen and spore terminology. Review of Palaeobotany and Palynology 143, 1-81.

Quénéa, K., Derenne, S., Rumpel, C., Rouzaud, J.N., Gustafsson, O., Carcaillet, C., Mariotti, A., Largeau, C., 2006. Black carbon yields and types in forest and cultivated sandy soils (Landes de Gascogne, France) as determined with different methods: Influence of change in land use. Organic Geochemistry 37, 1185-1189.

Ramos-Román, M.J., Jiménez-Moreno, G., Camuera, J., García-Alix, A., Scott Anderson, R., Jiménez-Espejo, F.J., Sachse, D., Toney, J.L., Carrión, J.S., Webster, C., Yanes, Y., 2018. Millennial-scale cyclical environment and climate variability during the Holocene in the western Mediterranean region deduced from a new multi-proxy analysis from the Padul record (Sierra Nevada, Spain). Global and Planetary Change 168, 35-53.

Reille, M., de Beaulieu, J.-L., Svobodova, V., Andrieu-Ponel, V., Goeury, C., 2000. Pollen analytical biostratigraphy of the last five climatic cycles from a long continental sequence from the Velay region (Massif Central, France). Journal of Quaternary Science 15, 665-685. Reistma, T.J., 1969. Size modification of recent pollen grains under different treatments. Review of Palynology and Paleobotany 9, 175-202.

Reitalu, T., Seppä, H., Sugita, S., Kangur, M., Koff, T., Avel, E., Kihno, K., Vassiljev, J., Renssen, H., Hammarlund, D., Heikkilä, M., Saarse, L., Poska, A., Veski, S., 2013. Longterm drivers of forest composition in a boreonemoral region: the relative importance of climate and human impact. Journal of Biogeography 40, 1524-1534.

Reyes, A.V., Carlson, A.E., Beard, B.L., Hatfield, R.G., Stoner, J.S., Winsor, K., Welke, B., Ullman, D.J., 2014. South Greenland ice-sheet collapse during Marine Isotope Stage[thinsp]11. Nature 510, 525-528.

Rhodes, A.N., 1998. A method for the preparation and quantification of microscopic charcoal from terrestrial and lacustrine sediment cores. The Holocene 8, 113-117.

Rius, D., Vannière, B., Galop, D., 2009. Fire frequency and landscape management in the northwestern Pyrenean piedmont, France, since the early Neolithic (8000 cal. BP). The Holocene 19, 847-859.

Rius, D., Vannière, B., Galop, D., Richard, H., 2011. Holocene fire regime changes from multiple-site sedimentary charcoal analyses in the Lourdes basin (Pyrenees, France).

Quaternary Science Reviews 30, 1696-1709. 
Roberts, N., Fyfe, R.M., Woodbridge, J., Gaillard, M.J., Davis, B.A.S., Kaplan, J.O., Marquer, L., Mazier, F., Nielsen, A.B., Sugita, S., Trondman, A.K., Leydet, M., 2018. Europe's lost forests: a pollen-based synthesis for the last 11,000 years. Scientific Reports 8, 716.

Rossignol-Strick, M., Duzer, D., 1979. West African vegetation and climate since 22, 500 B.P. from deep-sea cores palynology. Pollen et Spores 21, 105-134.

Roucoux, K.H., de Abreu, L., Shackleton, N.J., Tzedakis, P.C., 2005. The response of NW Iberian vegetation to North Atlantic climate oscillations during the last $65 \mathrm{kyr}$. Quaternary Science Reviews 24, 1637-1653.

Rovner, I., 1971. Potential of opal phytoliths for use in paleoecological reconstruction. Quaternary Research 1, 343-359.

Rowe, H.D., Dunbar, R.B., Mucciarone, D.A., Seltzer, G.O., Baker, P.A., Fritz, S., 2002. Insolation, Moisture Balance and Climate Change on the South American Altiplano Since the Last Glacial Maximum. Climatic Change 52, 175-199.

Ruddiman, W.F., 2001. Earth's Climate: Past and Future. W.H. Freeman \& Sons, New York. Ruddiman, W.F., Fuller, D.Q., Kutzbach, J.E., Tzedakis, P.C., Kaplan, J.O., Ellis, E.C., Vavrus, S.J., Roberts, C.N., Fyfe, R., He, F., Lemmen, C., Woodbridge, J., 2016. Late Holocene climate: Natural or anthropogenic? Reviews of Geophysics 54, 93-118.

Rull, V., 1987. A note on pollen counting in paleoecology. Pollen et Spores 29, 471-480. Runge, F., 1999. The opal phytolith inventory of soils in central Africa —quantities, shapes, classification, and spectra. Review of Palaeobotany and Palynology 107, 23-53.

Sadori, L., Koutsodendris, A., Panagiotopoulos, K., Masi, A., Bertini, A., Combourieu-Nebout, N., Francke, A., Kouli, K., Joannin, S., Mercuri, A.M., Peyron, O., Torri, P., Wagner, B., Zanchetta, G., Sinopoli, G., Donders, T.H., 2016. Pollen-based paleoenvironmental and paleoclimatic change at Lake Ohrid (south-eastern Europe) during the past $500 \mathrm{ka}$.

Biogeosciences 13, 1423-1437.

Salzmann, U., Hoelzmann, P., 2005. The Dahomey Gap: an abrupt climatically induced rain forest fragmentation in West Africa during the late Holocene. The Holocene 15, 190-199.

Salzmann, U., Hoelzmann, P., Morczinek, I., 2002. Late Quaternary Climate and Vegetation of the Sudanian Zone of Northeast Nigeria. Quaternary Research 58, 73-83.

Samartin, S., Heiri, O., Joos, F., Renssen, H., Franke, J., Brönnimann, S., Tinner, W., 2017. Warm Mediterranean mid-Holocene summers inferred from fossil midge assemblages. Nature Geoscience 10, 207.

Sánchez Goñi, M., Cacho, I., Turon, J., Guiot, J., Sierro, F., Peypouquet, J., Grimalt, J., Shackleton, N., 2002. Synchroneity between marine and terrestrial responses to millennial scale climatic variability during the last glacial period in the Mediterranean region. Climate dynamics 19, 95-105.

Sánchez Goñi, M.F., Desprat, S., Daniau, A.L., Bassinot, F.C., Polanco-Martínez, J.M., Harrison, S.P., Allen, J.R.M., Anderson, R.S., Behling, H., Bonnefille, R., Burjachs, F., Carrión, J.S., Cheddadi, R., Clark, J.S., Combourieu-Nebout, N., Mustaphi, Debusk, G.H., Dupont, L.M., Finch, J.M., Fletcher, W.J., Giardini, M., González, C., Gosling, W.D., Grigg, L.D., Grimm, E.C., Hayashi, R., Helmens, K., Heusser, L.E., Hill, T., Hope, G., Huntley, B., Igarashi, Y., Irino, T., Jacobs, B., Jiménez-Moreno, G., Kawai, S., Kershaw, A.P., Kumon, F., Lawson, I.T., Ledru, M.P., Lézine, A.M., Liew, P.M., Magri, D., Marchant, R., Margari, V., Mayle, F.E., McKenzie, G.M., Moss, P., Müller, S., Müller, U.C., Naughton, F., Newnham, R.M., Oba, T., Pérez-Obiol, R., Pini, R., Ravazzi, C., Roucoux, K.H., Rucina, S.M., Scott, L., Takahara, H., Tzedakis, P.C., Urrego, D.H., van Geel, B., Valencia, B.G., Vandergoes, M.J., Vincens, A., Whitlock, C.L., Willard, D.A., Yamamoto, M., 2017. The ACER pollen and charcoal database: a global resource to document vegetation and fire response to abrupt climate changes during the last glacial period. Earth Syst. Sci. Data 9, 679-695.

Sánchez Goñi, M.F., Desprat, S., Fletcher, W.J., Morales-Molino, C., Naughton, F., Oliveira, D., Urrego, D.H., Zorzi, C., 2018. Pollen from the Deep-Sea: A Breakthrough in the Mystery of the Ice Ages. Frontiers in Plant Science 9.

Sánchez Goñi, M.F., Eynaud, F., Turon, J.-L., Gendreau, S., 2000a. European climatic response to millenial-scale climatic changes in the atmosphere-ocean system during the Last Glacial period. Quaternary Research 54, 394-403. 
Sánchez Goñi, M.F., Eynaud, F., Turon, J.-L., Lancelot, Y., 1999. Land-sea environmental instability during the Last Glacial period: a high resolution pollen-dinocyst record off the Iberian margin. The Journal of Conference Abstracts 4, 166.

Sanchez Goñi, M.F., Harrison, S.P., 2010. Vegetation Response to Millennial-scale Variability during the Last Glacial. Quaternary Science Reviews 29, 2823-2980.

Sánchez Goñi, M.F., Landais, A., Fletcher, W., Naughton, F., Desprat, S., Duprat, J., 2008. Contrasting impacts of Dansgaard-Oeschger events over a western European latitudinal transect modulated by orbital parameters. Quaternary Science Reviews 27, 1136-1151. Sánchez Goñi, M.F., Turon, J.-L., Eynaud, F., Gendreau, S., 2000b. European climatic response to millenial-scale climatic changes in the atmosphere-ocean system during the Last Glacial period. Quaternary Research 54, 394-403.

Schüler, L., Hemp, A., 2016. Atlas of pollen and spores and their parent taxa of Mt Kilimanjaro and tropical East Africa. Quaternary International 425, 301-386.

Scott, L., 1982. Late quaternary fossil pollen grains from the Transvaal, South Africa. Review of Palaeobotany and Palynology 36, 241-278.

Scurfield, G., Anderson, C., Segnit, E., 1974. Silica in Woody Stems. Australian Journal of Botany 22, 211-229.

Settele, J., Scholes, R., Betts, R., Bunn, S., Leadley, P., Nepstad, D., Overpeck, J.T., Taboada, M.A., 2014. Terrestrial and Inland Water Systems, in: Intergovernmental Panel on Climate, C. (Ed.), Climate Change 2014 - Impacts, Adaptation and Vulnerability: Part A: Global and Sectoral Aspects: Working Group II Contribution to the IPCC Fifth Assessment Report: Volume 1: Global and Sectoral Aspects. Cambridge University Press, Cambridge, pp. 271-360.

Shanahan, T.M., Hughen, K.A., McKay, N.P., Overpeck, J.T., Scholz, C.A., Gosling, W.D., Miller, C.S., Peck, J.A., King, J.W., Heil, C.W., 2016. CO2 and fire influence tropical ecosystem stability in response to climate change. Scientific Reports 6, 29587.

Shanahan, T.M., McKay, N.P., Hughen, K.A., Overpeck, J.T., Otto-Bliesner, B., Heil, C.W., King, J., Scholz, C.A., Peck, J., 2015. The time-transgressive termination of the African Humid Period. Nature Geoscience 8, 140.

Shennan, S., Downey, S.S., Timpson, A., Edinborough, K., Colledge, S., Kerig, T., Manning, K., Thomas, M.G., 2013. Regional population collapse followed initial agriculture booms in mid-Holocene Europe. Nature Communications 4, 2486.

Shuman, B., Bartlein, P., Logar, N., Newby, P., Webb, I., T., 2002a. Parallel climate and vegetation responses to the early Holocene collapse of the Laurentide Ice Sheet. Quaternary Science Reviews 21, 1793-1805.

Shuman, B., Webb III, T., Bartlein, P., Williams, J.W., 2002b. The anatomy of a climatic oscillation: vegetation changein eastern North America during the Younger Dryas

chronozone. Quaternary Science Reviews 21, 1777-1791.

Siegenthaler, U., Stocker, T.F., Monnin, E., Lüthi, D., Schwander, J., Stauffer, B., Raynaud, D., Barnola, J.-M., Fischer, H., Masson-Delmotte, V., Jouzel, J., 2005. Stable Carbon Cycle\&\#150;Climate Relationship During the Late Pleistocene. Science 310, 1313-1317. Smith, R.J., Mayle, F.E., 2018. Impact of mid- to late Holocene precipitation changes on vegetation across lowland tropical South America: a paleo-data synthesis. Quaternary Research 89, 134-155.

Soepboer, W., Sugita, S., Lotter, A.F., 2010. Regional vegetation-cover changes on the Swiss Plateau during the past two millennia: A pollen-based reconstruction using the REVEALS model. Quaternary Science Reviews 29, 472-483.

Stevenson, J., Haberle, S., 2005. Macro Charcoal Analysis: A modified technique used by the Department of Archaeology and Natural History, PalaeoWorks Technical Report. ANU School of Culture, History and Language.

Strömberg, C.A.E., 2002. The origin and spread of grass-dominated ecosystems in the late Tertiary of North America: preliminary results concerning the evolution of hypsodonty. Palaeogeography, Palaeoclimatology, Palaeoecology 177, 59-75. 
Strömberg, C.A.E., 2004. Using phytolith assemblages to reconstruct the origin and spread of grass-dominated habitats in the great plains of North America during the late Eocene to early Miocene. Palaeogeography, Palaeoclimatology, Palaeoecology 207, 239-275.

Strömberg, C.A.E., Dunn, R.E., Crifò, C., Harris, E.B., 2018. Phytoliths in Paleoecology: Analytical Considerations, Current Use, and Future Directions, in: Croft, D.A., Su, D.F., Simpson, S.W. (Eds.), Methods in Paleoecology: Reconstructing Cenozoic Terrestrial Environments and Ecological Communities. Springer International Publishing, Cham, pp. 235-287.

Strömberg, C.A.E., Dunn, R.E., Madden, R.H., Kohn, M.J., Carlini, A.A., 2013. Decoupling the spread of grasslands from the evolution of grazer-type herbivores in South America. Nature Communications 4, 1478.

Struve, G.A., 1835. De Silicia in Plantis nonnullis : dissertatio inauguralis, \&c., Berolini. Sugita, S., 1993. A Model of Pollen Source Area for an Entire Lake Surface. Quaternary Research 39, 239-244.

Sugita, S., 1994. Pollen Representation of Vegetation in Quaternary Sediments: Theory and Method in Patchy Vegetation. Journal of Ecology 82, 881-897.

Sugita, S., 2007a. Theory of quantitative reconstruction of vegetation I: pollen from large sites REVEALS regional vegetation composition. The Holocene 17, 229-241.

Sugita, S., 2007b. Theory of quantitative reconstruction of vegetation II: all you need is LOVE. The Holocene 17, 243-257.

Sugita, S., Hicks, S., Sormunen, H., 2010. Absolute pollen productivity and pollen-vegetation relationships in northern Finland. Journal of Quaternary Science 25, 724-736.

Sun, X., Luo, Y., Huang, F., Tian, J., Wang, P., 2003. Deep-sea pollen from the South China Sea: Pleistocene indicators of East Asian monsoon. Marine Geology 201, 97-118.

Swain, A.M., 1973. A history of fire and vegetation in northeastern Minnesota as recorded in lake sediments. Quaternary Research 3, 383-396.

Tarasov, P., Williams, J.W., Andreev, A., Nakagawa, T., Bezrukova, E., Herzschuh, U., Igarashi, Y., Müller, S., Werner, K., Zheng, Z., 2007. Satellite- and pollen-based quantitative woody cover reconstructions for northern Asia: Verification and application to late-Quaternary pollen data. Earth and Planetary Science Letters 264, 284-298.

Tarasov, P.E., Cheddadi, R., Guiot, J., Bottema, S., Peyron, O., Belmonte, J., Ruiz-Sanchez, V., Saadi, F., Brewer, S., 1998. A method to determine warm and cool steppe biomes from pollen data; application to the Mediterranean and Kazakhstan regions. Journal of Quaternary Science 13, 335-344.

Tenzer, R., Gladkikh, V., 2014. Assessment of Density Variations of Marine Sediments with Ocean and Sediment Depths. The Scientific World Journal 2014, 9.

Theuerkauf, M., Couwenberg, J., Kuparinen, A., Liebscher, V., 2016. A matter of dispersal: REVEALSinR introduces state-of-the-art dispersal models to quantitative vegetation reconstruction. Vegetation History and Archaeobotany 25, 541-553.

Thevenon, F., Bard, E., Williamson, D., Beaufort, L., 2004. A biomass burning record from the West Equatorial Pacific over the last 360 kyr: methodological, climatic and anthropic implications. Paleogeography, Paleoclimatology, Paleoecology 213, 83-99.

Thompson, R.S., 2013. POLLEN RECORDS, LATE PLEISTOCENE | Western North America, in: Elias, S.A., Mock, C.J. (Eds.), Encyclopedia of Quaternary Science (Second Edition). Elsevier, Amsterdam, pp. 72-83.

Tinner, W., Conedera, M., Ammann, B., Gaggeler, H.W., Gedye, S., Jones, R., Sagesser, B., 1998. Pollen and charcoal in lake sediments compared with historically documented forest fires in southern Switzerland since AD 1920. The Holocene 8, 31-42.

Tinner, W., Conedera, M., Ammann, B., Lotter, A.F., 2005. Fire ecology north and south of the Alps since the last ice age. The Holocene 15, 1214-1226.

Tinner, W., Hofstetter, S., Zeugin, F., Conedera, M., Wohlgemuth, T., Zimmermann, L., Zweifel, R., 2006. Long-distance transport of macroscopic charcoal by an intensive crown fire in the Swiss Alps - implications for fire history reconstruction. The Holocene 16, 287-292. 
Tinner, W., Hu, F.S., 2003. Size parameters, size-class distribution and area-number relationship of microscopic charcoal: relevance for fire reconstruction. The Holocene 13, 499505.

Tinner, W., Hubschmid, P., Wehrli, M., Ammann, B., Conedera, M., 1999. Long-term forest fire ecology and dynamics in southern Switzerland. Journal of Ecology 87, 273-289.

Tinner, W., Lotter, A.F., 2001. Central European vegetation response to abrupt climate change at $8.2 \mathrm{ka}$. Geology 29, 551-554.

Tinner, W., Lotter, A.F., 2006. Holocene expansions of Fagus silvatica and Abies alba in Central Europe: where are we after eight decades of debate? Quaternary Science Reviews 25, 526-549.

Tolonen, K., 1986. Charred particle analysis, in: Berglund, B.E. (Ed.), Handbook of Holocene Palaeoecology and Palaeohidrology. John Wiley \& Sons Ltd., pp. 485-496.

Torres, V., Hooghiemstra, H., Lourens, L., Tzedakis, P.C., 2013. Astronomical tuning of long pollen records reveals the dynamic history of montane biomes and lake levels in the tropical high Andes during the Quaternary. Quaternary Science Reviews 63, 59-72.

Toucanne, S., Zaragosi, S., Bourillet, J.F., Cremer, M., Eynaud, F., Van Vliet-Lanoë, B., Penaud, A., Fontanier, C., Turon, J.L., Cortijo, E., Gibbard, P.L., 2009. Timing of massive 'Fleuve Manche' discharges over the last 350kyr: insights into the European ice-sheet oscillations and the European drainage network from MIS 10 to 2. Quaternary Science Reviews 28, 1238-1256.

Tovar, C., Breman, E., Brncic, T., Harris, D.J., Bailey, R., Willis, K.J., 2014. Influence of 1100 years of burning on the central African rainforest. Ecography 37, 1139-1148.

Traverse, A., 2007. Paleopalynology, Second Edition ed. Springer Netherlands.

Trondman, A.K., Gaillard, M.J., Mazier, F., Sugita, S., Fyfe, R., Nielsen, A.B., Twiddle, C., Barratt, P., Birks, H.J.B., Bjune, A.E., Björkman, L., Broström, A., Caseldine, C., David, R., Dodson, J., Dörfler, W., Fischer, E., van Geel, B., Giesecke, T., Hultberg, T., Kalnina, L., Kangur, M., van der Knaap, P., Koff, T., Kuneš, P., Lagerås, P., Latalowa, M., Lechterbeck, J., Leroyer, C., Leydet, M., Lindbladh, M., Marquer, L., Mitchell, F.J.G., Odgaard, B.V., Peglar, S.M., Persson, T., Poska, A., Rösch, M., Seppä, H., Veski, S., Wick, L., 2015. Pollenbased quantitative reconstructions of Holocene regional vegetation cover (plant-functional types and land-cover types) in Europe suitable for climate modelling. Global Change Biology 21, 676-697.

Trondman, A.K., Gaillard, M.J., Sugita, S., Björkman, L., Greisman, A., Hultberg, T., Lagerås, P., Lindbladh, M., Mazier, F., 2016. Are pollen records from small sites appropriate for REVEALS model-based quantitative reconstructions of past regional vegetation? An empirical test in southern Sweden. Vegetation History and Archaeobotany 25, 131-151. Turner, C., 1998. Volcanic maars, long quaternary sequences and the work of the INQUA Subcommission on European Quaternary Stratigraphy. Quaternary International 47/48, 4149.

Turner, C., West, R.G., 1968. The subdivision and zonation of interglacial period. Eiszeitalter und Gegenwart 19, 93-101.

Turon, J.-L., 1984. Le palynoplancton dans l'environnement actuel de l'Atlantique nordoriental. Evolution climatique et hydrologique depuis le dernier maximum glaciaire. Université de Bordeaux I, Bordeaux.

Twiss, P.C., Suess, E., Smith, R.M., 1969. Morphological classification of grass phytoliths. Soil Science Society of America Journal 33, 109-115.

Tzedakis, P.C., 1993. Long-term tree populations in northwest Greece through multiple Quaternary cycles. Nature 364, 437-440.

Tzedakis, P.C., 2005. Towards an understanding of the response of southern European vegetation to orbital and suborbital climate variability. Quaternary Science Reviews 24, 1585-1599.

Tzedakis, P.C., 2007. Seven ambiguities in the Mediterranean palaeoenvironmental narrative. Quaternary Science Reviews 26, 2042-2066.

Tzedakis, P.C., Andrieu, V., De Beaulieu, J.L., Crowhurst, S., Follieri, M., Hooghiemstra, H., Magri, D., Reille, M., Sadori, L., Shackleton, N.J., Wijmstra, T.A., 1997. Comparison of 
terrestrial and marine records of changing climate of the last 500,000 years. Earth and Planetary Science Letters 150, 171-176.

Tzedakis, P.C., Crucifix, M., Mitsui, T., Wolff, E.W., 2017. A simple rule to determine which insolation cycles lead to interglacials. Nature 542, 427-432.

Tzedakis, P.C., Hooghiemstra, H., Pälike, H., 2006. The last 1.35 million years at Tenaghi Philippon: revised chronostratigraphy and long-term vegetation trends. Quaternary Science Reviews 25, 3416-3430.

Umbanhowar, C.E.J., McGrath, M.J., 1998. Experimental production and analysis of microscopic charcoal from wood, leaves and grasses. The Holocene 8 8, 341-346.

Urrego, D.H., Bernal, J.P., Chiessi, C.M., Cruz, F.W., Sanchez Goñi, M.F., Power, M., Hooghiemstra, H., participants, L., 2014. Millennial-scale climate variability in the American tropics and subtropics. PAGES Magazine 22, 94-95.

Urrego, D.H., Bush, M.B., Silman, M.R., 2010. A long history of cloud and forest migration from Lake Consuelo, Peru. Quaternary Research 73, 364-373.

Urrego, D.H., Bush, M.B., Silman, M.R., Correa-Metrio, A.Y., Ledru, M.-P., Mayle, F.E., Paduano, G., Valencia, B.G., 2009. Millennial-Scale Ecological Changes in Tropical South America Since the Last Glacial Maximum, in: Vimeux, F., Sylvestre, F., Khodri, M. (Eds.), Past Climate Variability in South America and Surrounding Regions: From the Last Glacial Maximum to the Holocene. Springer Netherlands, Dordrecht, pp. 283-300.

Urrego, D.H., Bush, M.B., Silman, M.R., Niccum, B.A., De La Rosa, P., McMichael, C.H., Hagen, S., Palace, M., 2013a. Holocene fires, forest stability and human occupation in southwestern Amazonia. Journal of Biogeography 40, 521-533.

Urrego, D.H., Bush, M.B., Silman, M.R., Niccum, B.A., La Rosa, P., McMichael, C.H., Hagen, S., Palace, M., 2013b. Holocene fires, forest stability and human occupation in south-western Amazonia. Journal of Biogeography 40, 521-533.

Urrego, D.H., Hooghiemstra, H., Rama-Corredor, O., Martrat, B., Grimalt, J.O., Thompson, L., Bush, M.B., González-Carranza, Z., Hanselman, J., Valencia, B., Velásquez-Ruiz, C., 2016. Millennial-scale vegetation changes in the tropical Andes using ecological grouping and ordination methods. Clim. Past 12, 697-711.

Urrego, D.H., Sánchez Goñi, M.F., Daniau, A.L., Lechevrel, S., Hanquiez, V., 2015.

Increased aridity in southwestern Africa during the warmest periods of the last interglacial. Clim. Past 11, 1417-1431.

Valsecchi, V., Finsinger, W., Tinner, W., Ammann, B., 2008. Testing the influence of climate, human impact and fire on the Holocene population expansion of Fagus sylvatica in the southern Prealps (Italy). The Holocene 18, 603-614.

Van Der Wiel, A.M., Wijmstra, T.A., 1987a. Palynology of the 112.8-197.8 m interval of the core Tenaghi Philippon III, Middle Pleistocene of Macedonia. Review of Palaeobotany and Palynology 52, 89-"108,111-117".

Van Der Wiel, A.M., Wijmstra, T.A., 1987b. Palynology of the lower part (78-120 M) of the core Tenaghi Philippon II, Middle Pleistocene of Macedonia, Greece. Review of Palaeobotany and Palynology 52, 73-88.

van Gemerden, B.S., Olff, H., Parren, M.P.E., Bongers, F., 2003. The pristine rain forest? Remnants of historical human impacts on current tree species composition and diversity. Journal of Biogeography 30, 1381-1390.

Vannière, B., Blarquez, O., Rius, D., Doyen, E., Brücher, T., Colombaroli, D., Connor, S., Feurdean, A., Hickler, T., Kaltenrieder, P., Lemmen, C., Leys, B., Massa, C., Olofsson, J., 2016. 7000-year human legacy of elevation-dependent European fire regimes. Quaternary Science Reviews 132, 206-212.

Vannière, B., Colombaroli, D., Chapron, E., Leroux, A., Tinner, W., Magny, M., 2008. Climate versus human-driven fire regimes in Mediterranean landscapes: the Holocene record of Lago dell'Accesa (Tuscany, Italy). Quaternary Science Reviews 27, 1181-1196.

Vannière, B., Power, M.J., Roberts, N., Tinner, W., Carrión, J., Magny, M., Bartlein, P., Colombaroli, D., Daniau, A.L., Finsinger, W., Gil-Romera, G., Kaltenrieder, P., Pini, R., Sadori, L., Turner, R., Valsecchi, V., Vescovi, E., 2011. Circum-Mediterranean fire activity 
and climate changes during the mid-Holocene environmental transition (8500-2500 cal. BP). The Holocene 21, 53-73.

Velasquez, C.A., 1999. Atlas palinologico de la flora vascular Paramuna de Colombia:

Angiospermae. Universidad Nacional de Colombia \& Colciencias, Medellin, Colombia.

Verardo, D.J., 1997. Charcoal analysis in marine sediments. Limnology and Oceanography 42, 192-197.

Viau, A.E., Gajewski, K., 2009. Reconstructing Millennial-Scale, Regional Paleoclimates of Boreal Canada during the Holocene. Journal of Climate 22, 316-330.

Viau, A.E., Ladd, M., Gajewski, K., 2012. The climate of North America during the past 2000 years reconstructed from pollen data. Global and Planetary Change 84-85, 75-83. Villa-Martínez, R., Moreno, P.I., 2007. Pollen evidence for variations in the southern margin of the westerly winds in SW Patagonia over the last 12,600 years. Quaternary Research 68, 400-409.

Vincens, A., Buchet, G., Elenga, H., Fournier, M., Martin, L., de Namur, C., Schwartz, D., Servant, M. and Wirrmann, D., 1994. Changement majeur de la végétation du lac Sinnda (vallée du Niari, Sud-Congo) consécutif à l'assèchement climatique holocène supérieur: apport de la palynologie. Comptes Rendus de l'Académie des Sciences, Paris 318, $1521-$ 1526.

Vincens, A., Buchet, G., Servant, M., collaborators, E.M., 2010. Vegetation response to the "African Humid Period" termination in Central Cameroon $\left(7^{\circ} \mathrm{N}\right)-$ new pollen insight from Lake Mbalang. Clim. Past 6, 281-294.

Vincens, A., Garcin, Y., Buchet, G., 2007. Influence of rainfall seasonality on African lowland vegetation during the Late Quaternary: pollen evidence from Lake Masoko, Tanzania. Journal of Biogeography 34, 1274-1288.

Vincens, A., Schwartz, D., Bertaux, J., Elenga, H., de Namur, C., 1998. Late Holocene Climatic Changes in Western Equatorial Africa Inferred from Pollen from Lake Sinnda, Southern Congo. Quaternary Research 50, 34-45.

Vincens, A., Schwartz, D., Elenga, H., Reynaud-Farrera, I., Alexandre, A., Bertaux, J., Mariotti, A., Martin, L., Meunier, J.-D., Nguetsop, F., Servant, M., Servant-Vildary, S., Wirrmann, D., 1999. Forest response to climate changes in Atlantic Equatorial Africa during the last 4000 years BP and inheritance on the modern landscapes. Journal of Biogeography 26, 879-885.

Wang, X., Peng, P.A., Ding, Z.L., 2005. Black carbon records in Chinese Loess Plateau over the last two glacial cycles and implications for paleofires. Palaeogeography,

Palaeoclimatology, Palaeoecology 223, 9-19.

Watling, J., Iriarte, J., Mayle, F.E., Schaan, D., Pessenda, L.C.R., Loader, N.J., StreetPerrott, F.A., Dickau, R.E., Damasceno, A., Ranzi, A., 2017. Impact of pre-Columbian geoglyph builders on amazonian forests. Proceedings of the National Academy of Sciences of the United States of America 114, 1868-1873.

Webb, T., Shuman, B., Williams, J.W., 2003. Climatically forced vegetation dynamics in eastern North America during the late Quaternary Period, Developments in Quaternary Sciences. Elsevier, pp. 459-478.

Wenwei, Z., E., T.P., V., L.A., M., A.P., A., A.A., A., K.J., Martin, M., Y., N.E., Volker, W., 2018. High-latitude vegetation and climate changes during the Mid-Pleistocene Transition inferred from a palynological record from Lake El'gygytgyn, NE Russian Arctic. Boreas 47, 137-149.

Whitlock, C., 1992. Vegetational and climatic history of the Pacific Northwest during the last 20000 years: implications for understanding present-day biodiversity. Northwest

Environmental Journal 8, 5-28.

Whitlock, C., Brunelle, A., 2007. POLLEN RECORDS, POSTGLACIAL | Northwestern North America, in: Elias, S.A. (Ed.), Encyclopedia of Quaternary Science. Elsevier, Oxford, pp. 2736-2744.

Whitlock, C., Larsen, C., 2001. Charcoal as a fire proxy, in: Smol, J.P., Birks, H.J.B.,, Last, W.M. (Eds.), Tracking Environmental Changes Using Lake sediments. Kluwer Academic Publishers, Dordrecht, The Netherlands, pp. 75-96. 
Whitlock, C., Millspaugh, S.H., 1996. Testing the assumptions of fire-history studies: an examination of modern charcoal accumulation in Yellowstone National Park, USA. The Holocene 6, 7-15.

Whitmore, J., Gajewski, K., Sawada, M., Williams, J.W., Shuman, B., Bartlein, P.J., Minckley, T., Viau, A.E., Webb III, T., Shafer, S., 2005. Modern pollen data from North America and Greenland for multi-scale paleoenvironmental applications. Quaternary Science Reviews 24, 1828-1848.

Wigand, P.E., 2013. POLLEN RECORDS, POSTGLACIAL | Southwestern North America, in: Elias, S.A., Mock, C.J. (Eds.), Encyclopedia of Quaternary Science (Second Edition).

Elsevier, Amsterdam, pp. 142-155.

Wijmstra, T.A., 1969. Palynology of the first 30 metres of a $120 \mathrm{~m}$ deep section in Northern Greece. Acta Botanica Neerlandica 18, 511-527.

Wijmstra, T.A., Smit, A., 1976. Palynology of the middle part (30-78 metres) of the $120 \mathrm{~m}$ deep section in Northern Greece (Macedonia). Acta Botanica Neerlandica 25, 297-312.

Willard, D.A., 2013. POLLEN RECORDS, POSTGLACIAL | Southeastern North America, in: Elias, S.A., Mock, C.J. (Eds.), Encyclopedia of Quaternary Science (Second Edition). Elsevier, Amsterdam, pp. 133-141.

Willard, D.A., Bernhardt, C.E., Weimer, L., Cooper, S.R., Gamez, D., xe, Jensen, J., 2004. Atlas of Pollen and Spores of the Florida Everglades. Palynology 28, 175-227.

Williams, J.W., 2003. Variations in tree cover in North America since the last glacial maximum. Global and Planetary Change 35, 1-23.

Williams, J.W., Grimm, E.C., Blois, J.L., Charles, D.F., Davis, E.B., Goring, S.J., Graham, R.W., Smith, A.J., Anderson, M., Arroyo-Cabrales, J., Ashworth, A.C., Betancourt, J.L., Bills, B.W., Booth, R.K., Buckland, P.I., Curry, B.B., Giesecke, T., Jackson, S.T., Latorre, C., Nichols, J., Purdum, T., Roth, R.E., Stryker, M., Takahara, H., 2018. The Neotoma Paleoecology Database, a multiproxy, international, community-curated data resource. Quaternary Research 89, 156-177.

Williams, J.W., Shuman, B.N., 2013. POLLEN RECORDS, POSTGLACIAL | Northeastern North America, in: Elias, S.A., Mock, C.J. (Eds.), Encyclopedia of Quaternary Science (Second Edition). Elsevier, Amsterdam, pp. 115-123.

Williams, J.W., Shuman, B.N., Webb III, T., 2001. Dissimilarity analyses of Late-Quaternary vegetation and climate in Eastern North America. Ecology 82, 3346-3362.

Williams, J.W., Shuman, B.N., Webb III, T., Bartlein, P.J., Leduc, P.L., 2004. LateQuaternary vegetation dynamics in North America: scaling from taxa to biomes. Ecological Monographs 74, 309-334.

Williams, J.W., Tarasov, P., Brewer, S., Notaro, M., 2011. Late Quaternary variations in tree cover at the northern forest-tundra ecotone. Journal of Geophysical Research:

Biogeosciences 116.

Willis, K.J., Feurdean, A., Birks, H.J.B., Bjune, A.E., Breman, E., Broekman, R., Grytnes, J.A., New, M., Singarayer, J.S., Rozema, J., 2011. Quantification of UV-B flux through time using UV-B-absorbing compounds contained in fossil Pinus sporopollenin. New Phytologist 192, 553-560.

Winkler, M.G., 1985. Charcoal analysis for paleoenvironmental interpretation: A chemical assay. Quaternary Research 23, 313-326.

Woillez, M.N., Levavasseur, G., Daniau, A.L., Kageyama, M., Urrego, D.H., Sánchez-Goñi, M.F., Hanquiez, V., 2014. Impact of precession on the climate, vegetation and fire activity in southern Africa during MIS4. Clim. Past 10, 1165-1182.

Wolbach, W.S., Anders, E., 1989. Elemental carbon in sediments: Determination and isotopic analysis in the presence of kerogen. Geochimica et Cosmochimica Acta 53, 16371647.

Wolff, E.W., Chappellaz, J., Blunier, T., Rasmussen, S.O., Svensson, A., 2010. Millennialscale variability during the last glacial: The ice core record. Quaternary Science Reviews 29, 2828-2838. 
Wu, H., Guiot, J., Brewer, S., Guo, Z., 2007. Climatic changes in Eurasia and Africa at the last glacial maximum and mid-Holocene: reconstruction from pollen data using inverse vegetation modelling. Climate Dynamics 29, 211-229.

Xiao, X., Shen, J., Wang, S., Xiao, H., Tong, G., 2007. Palynological evidence for vegetational and climatic changes from the $\mathrm{HQ}$ deep drilling core in Yunnan Province, China. Science in China Series D: Earth Sciences 50, 1189-1201.

Xiao, X.Y., Shen, J., Wang, S.M., Xiao, H.F., Tong, G.B., 2010. The variation of the southwest monsoon from the high resolution pollen record in Heqing Basin, Yunnan Province, China for the last 2.78Ma. Palaeogeography, Palaeoclimatology, Palaeoecology 287, 45-57.

Yang, S., Zheng, Z., Mao, L., Ferguson, D.K., Huang, K., Chen, B., Ranhotra, P.S., 2015. Selected pollen grains from tropical Hainan Island, south China: An identification key to Quaternary pollen. Review of Palaeobotany and Palynology 222, 84-103.

Yin, Q.Z., Berger, A., 2010. Insolation and CO2 contribution to the interglacial climate before and after the Mid-Brunhes Event. Nature Geoscience 3, 243-246.

Yin, Q.Z., Berger, A., 2012. Individual contribution of insolation and CO2 to the interglacial climates of the past 800,000 years. Climate dynamics 38, 709-724.

Youta Happi, J., 1998. Arbres contre graminées: la lente invasion de la forêt par la savane au Centre-Cameroun, Université de Paris 4, Biogéogr. ed. Paris 4, Paris, p. 241.

Zagwijn, W.H., 1994. Reconstruction of climate change during the Holocene in western and central Europe based on pollen records of indicator species. Vegetation History and Archaeobotany 3, 65-88.

Zagwijn, W.H., 1996. The Cromerian Complex Stage of the Netherlands and correlation with other areas in Europe, in: Turner, C. (Ed.), The early Middle Pleistocene In Europe. Balkema, Rotterdam, pp. 145-172.

Zanon, M., Davis, B.A.S., Marquer, L., Brewer, S., Kaplan, J.O., 2018. European Forest Cover During the Past 12,000 Years: A Palynological Reconstruction Based on Modern Analogs and Remote Sensing. Frontiers in Plant Science 9.

Zheng, Z., Wei, J., Huang, K., Xu, Q., Lu, H., Tarasov, P., Luo, C., Beaudouin, C., Deng, Y., Pan, A., Zheng, Y., Luo, Y., Nakagawa, T., Li, C., Yang, S., Peng, H., Cheddadi, R., 2014. East Asian pollen database: modern pollen distribution and its quantitative relationship with vegetation and climate. Journal of Biogeography 41, 1819-1832.

Zhisheng, A., Clemens, S.C., Shen, J., Qiang, X., Jin, Z., Sun, Y., Prell, W.L., Luo, J., Wang, S., Xu, H., Cai, Y., Zhou, W., Liu, X., Liu, W., Shi, Z., Yan, L., Xiao, X., Chang, H., Wu, F., Ai, L., Lu, F., 2011. Glacial-interglacial Indian summer monsoon dynamics. Science 333, 719723. 
Figure 1

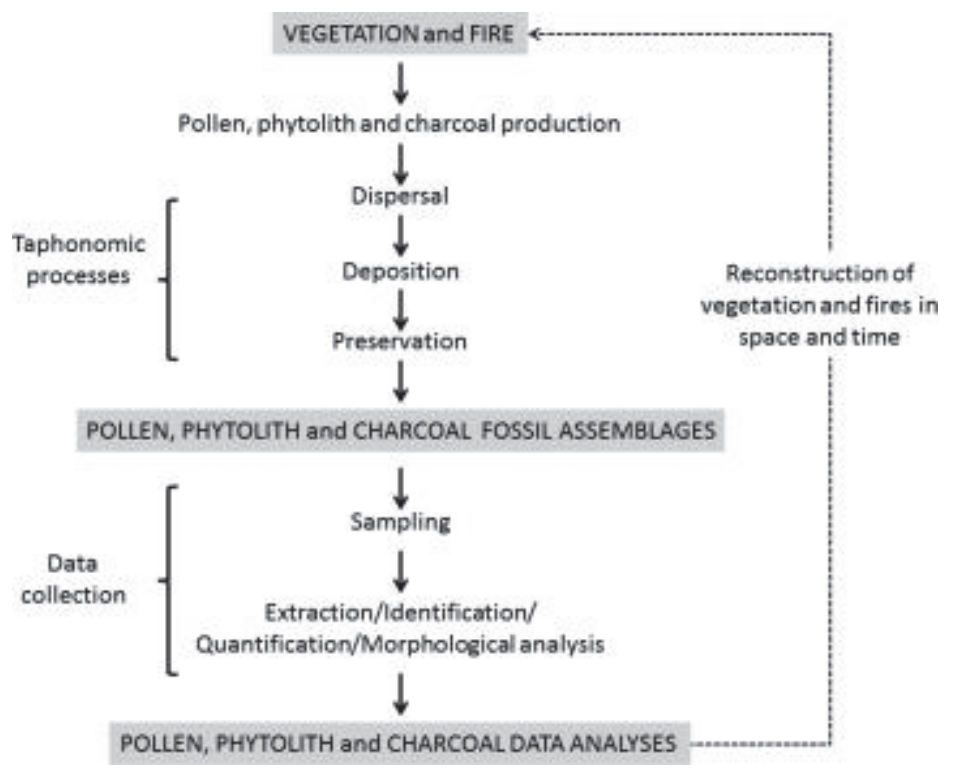


Figure 2
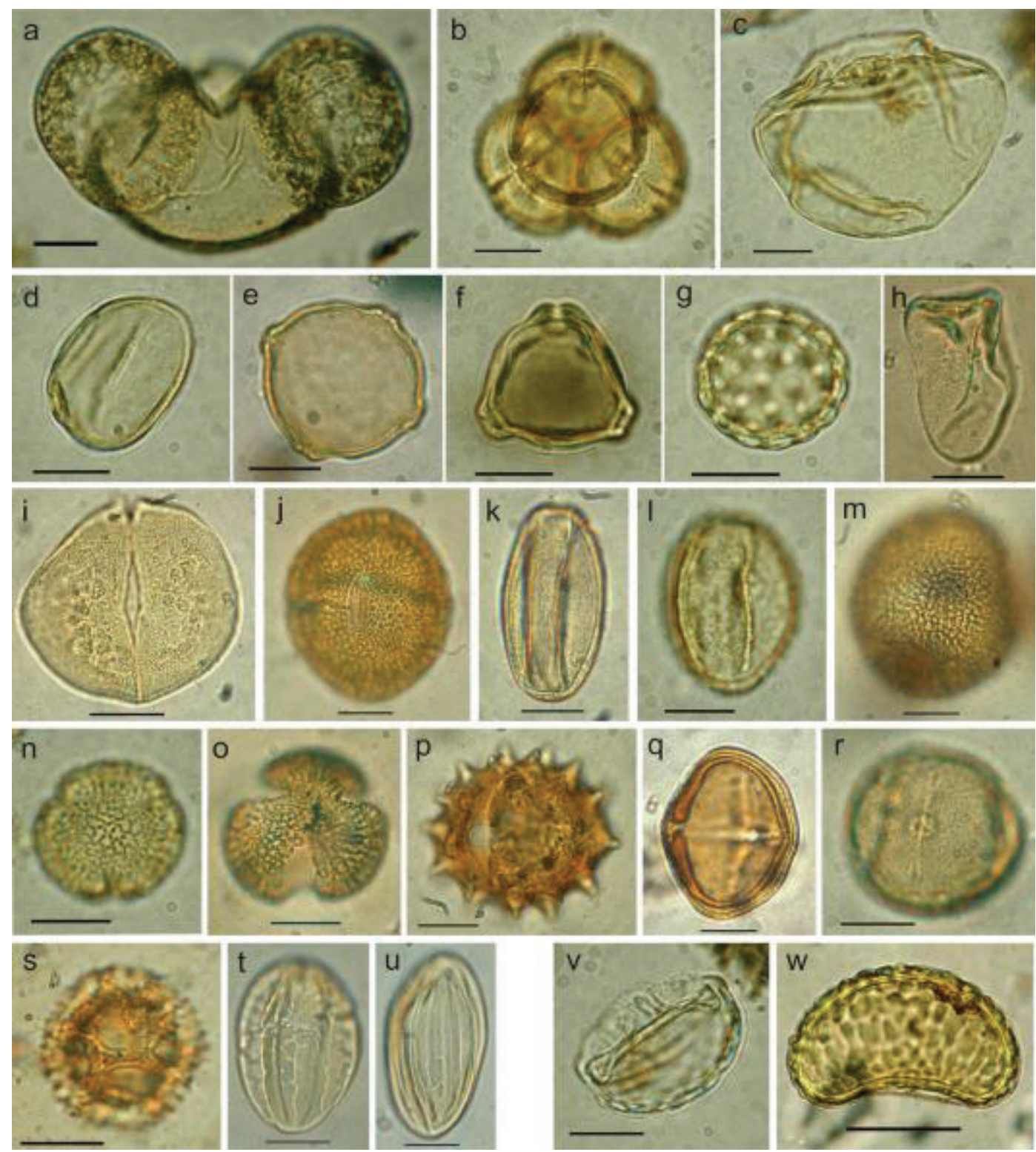
Figure 3
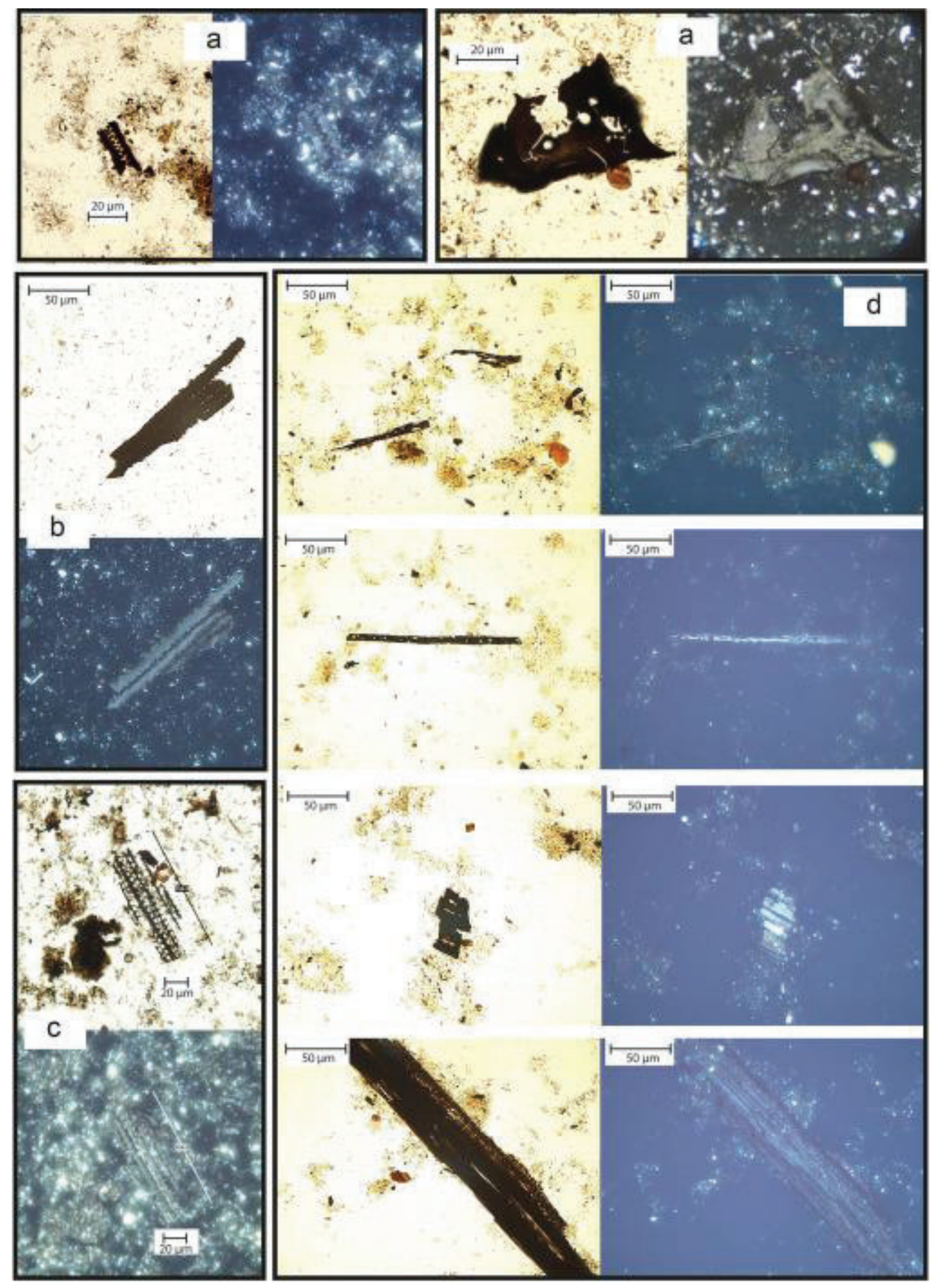
Figure 4
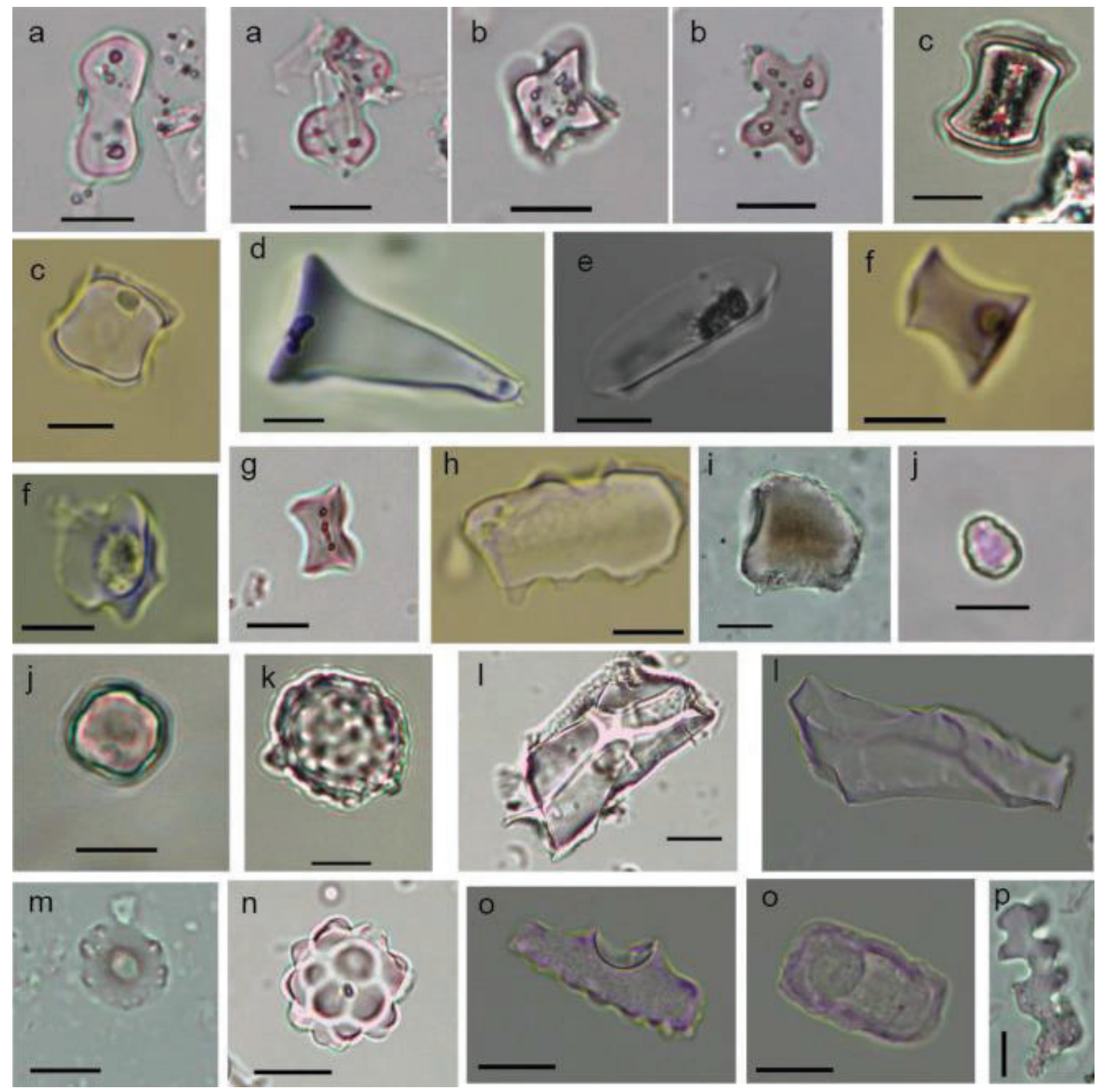
Figure 5

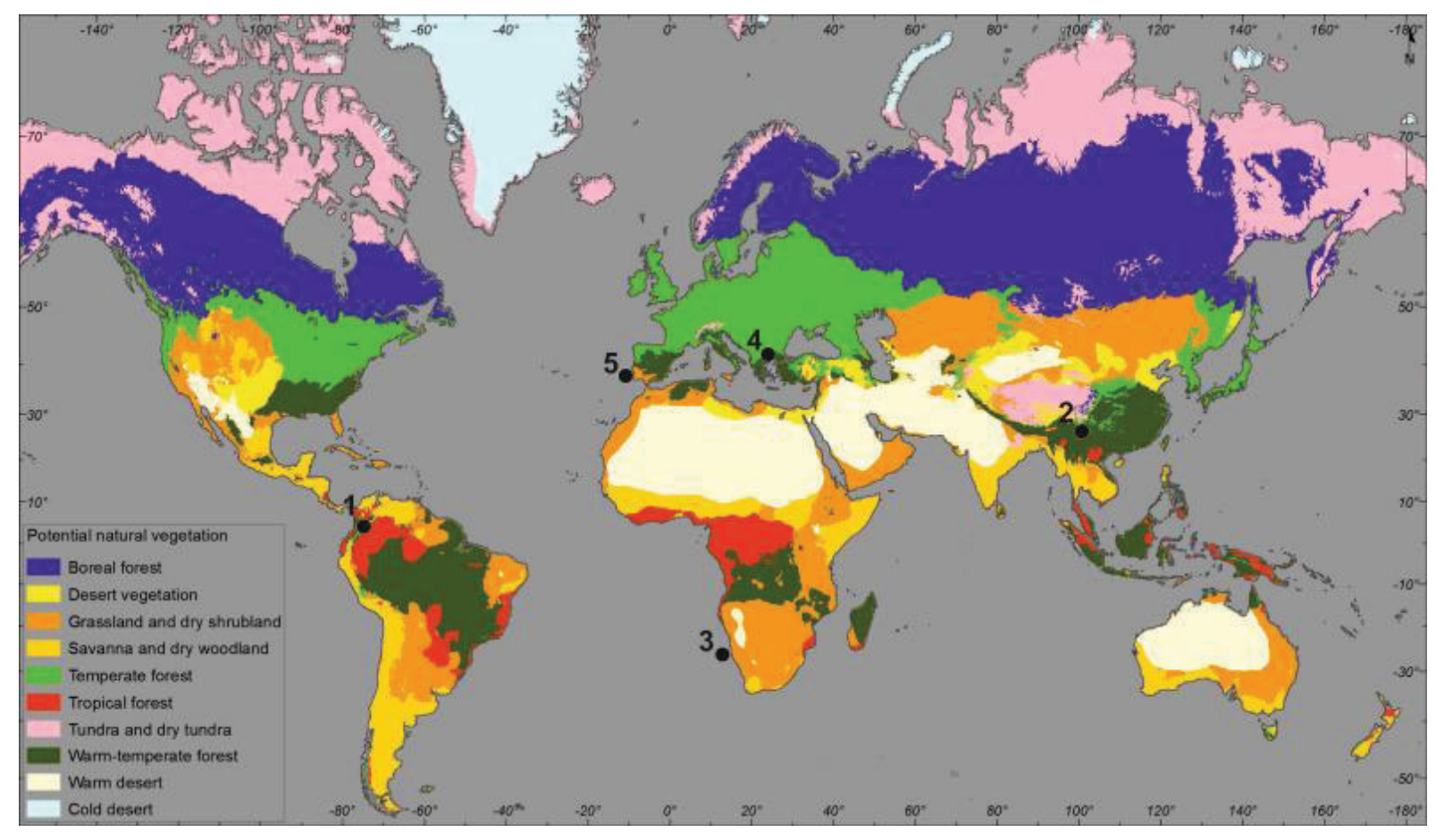


Figure 6

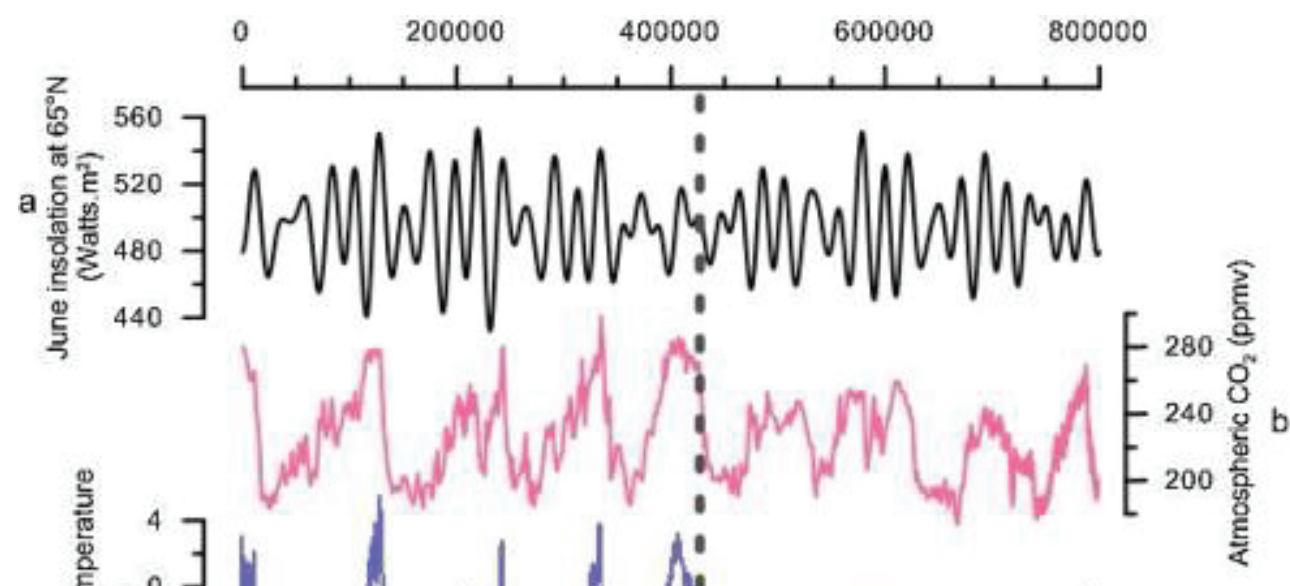

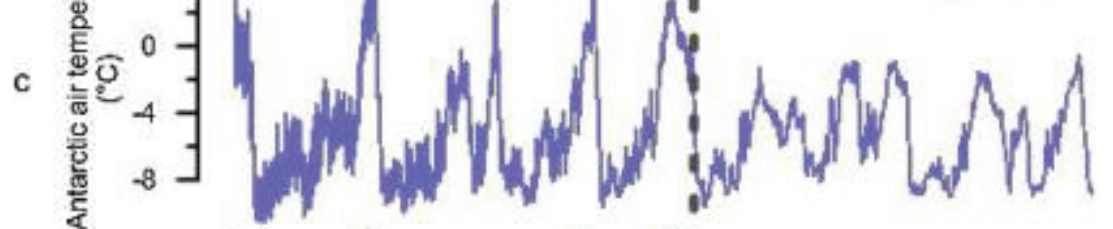

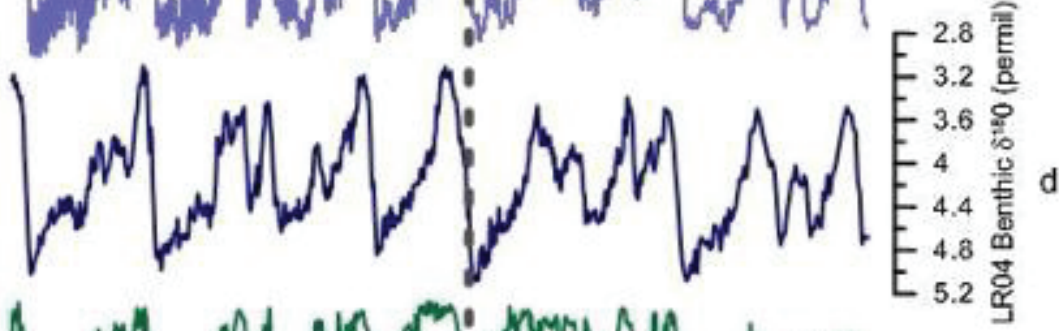

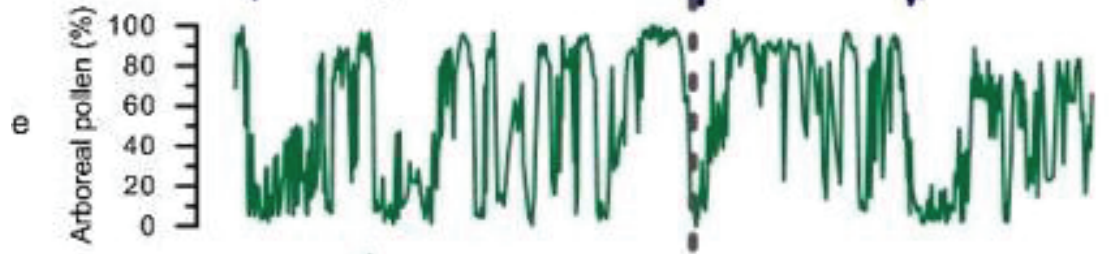

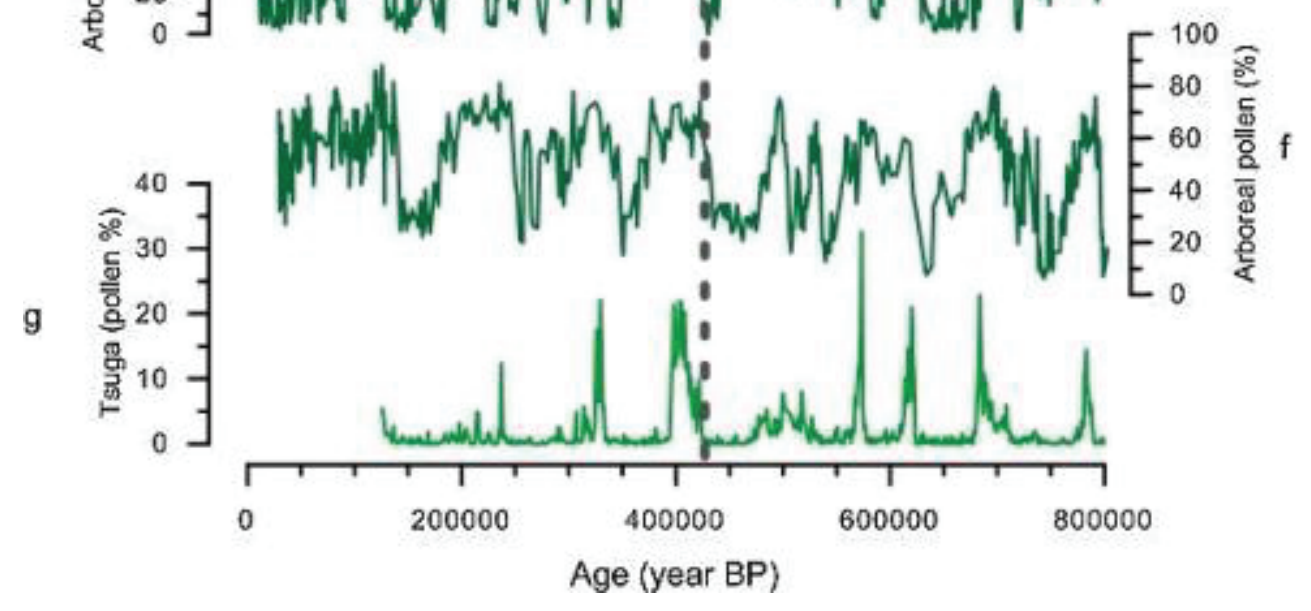


Figure 7

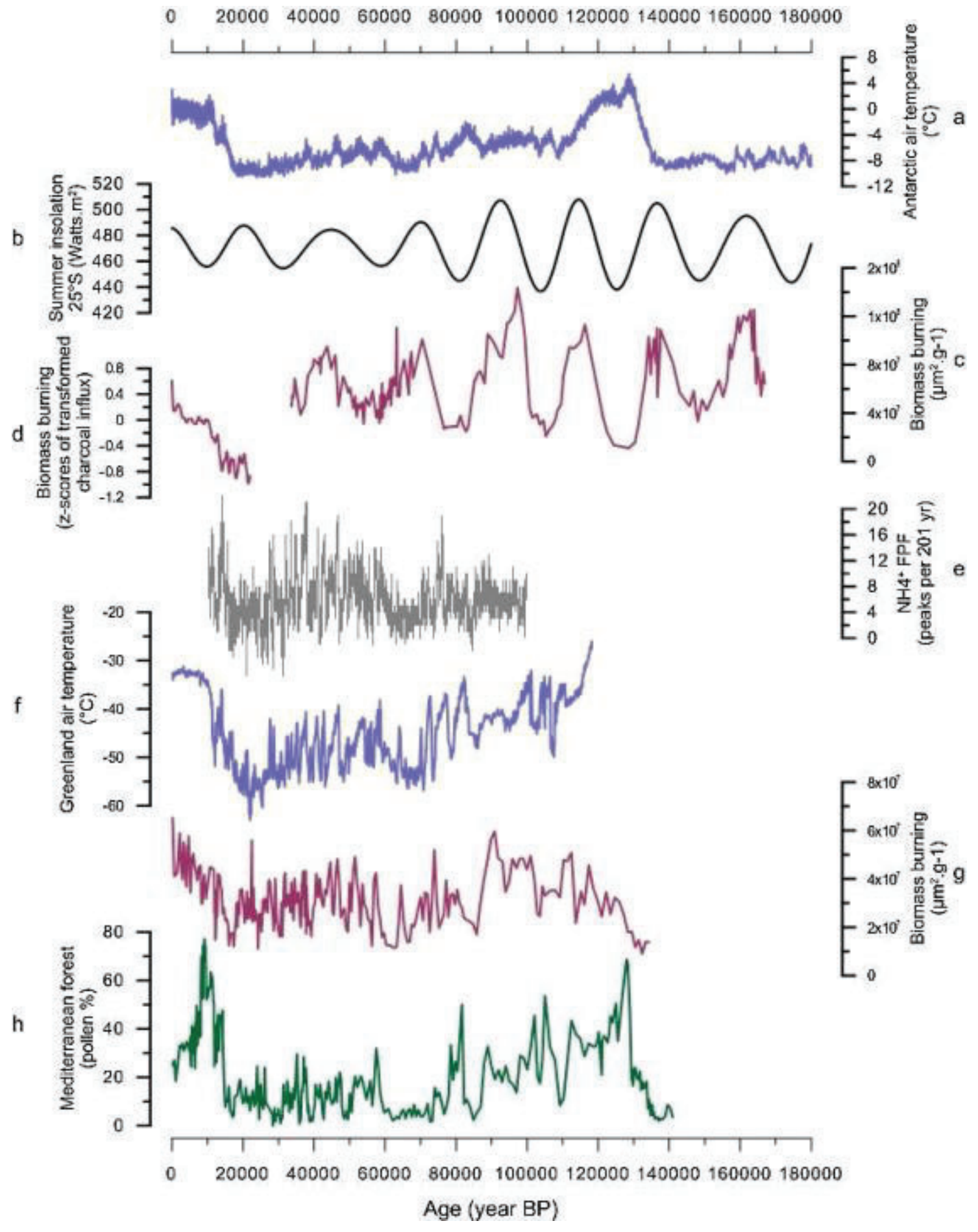


Figure 8

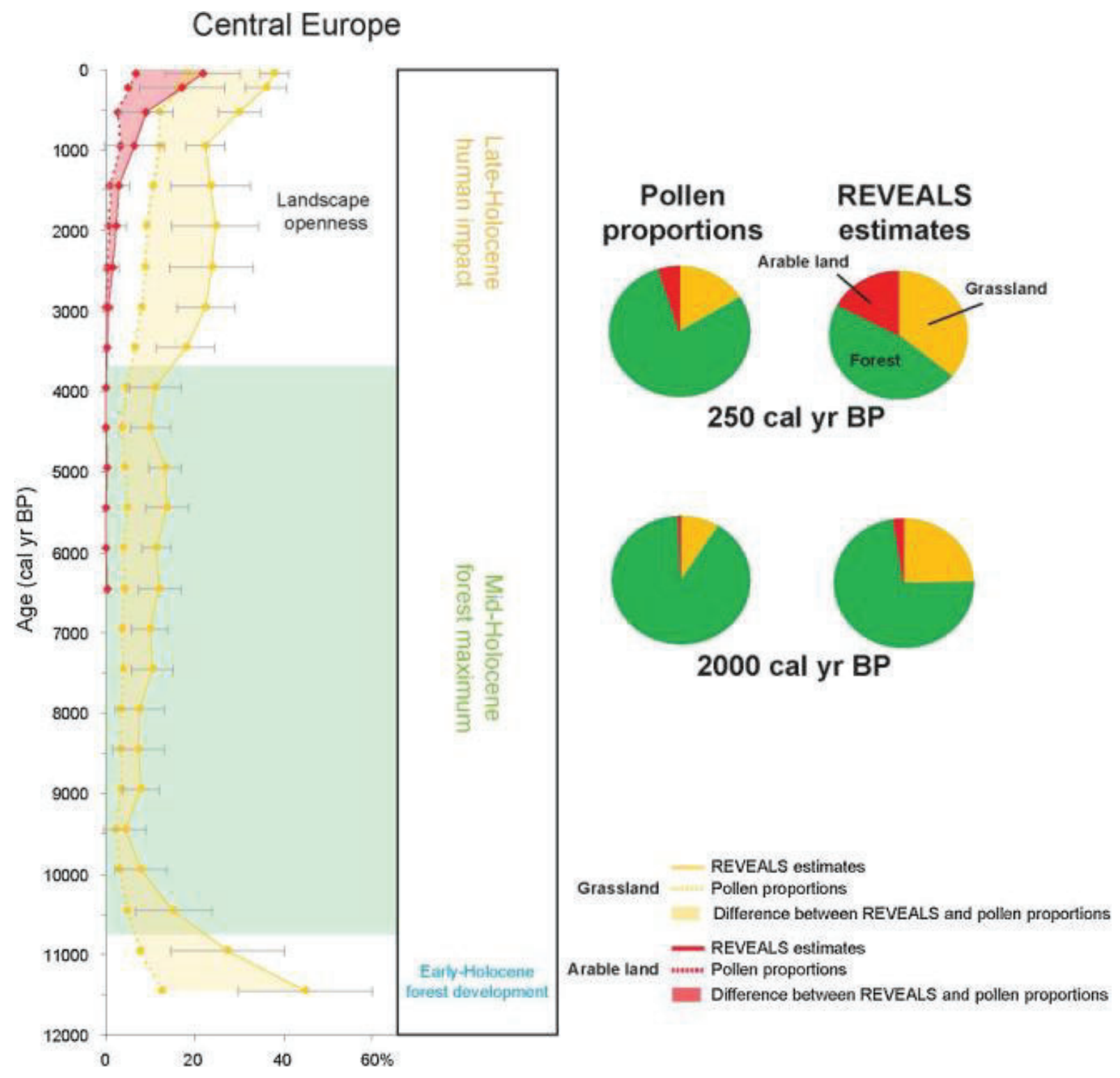

